Marina Sorrentino Hernandes

\title{
GERAÇÃO DE ESPÉCIES REATIVAS DE OXIGÊNIO E NEUROINFLAMAÇÃO INDUZIDAS POR ENUCLEAÇÃO OCULAR NO SISTEMA VISUAL DE RATOS
}

Tese apresentada ao Programa de Pós- Graduação em Fisiologia e Biofísica do Instituto de Ciências Biomédicas da Universidade de São Paulo, para obtenção do Título de Doutor em Ciências. 
Marina Sorrentino Hernandes

\section{GERAÇÃO DE ESPÉCIES REATIVAS DE OXIGÊNIO E NEUROINFLAMAÇÃO INDUZIDAS POR ENUCLEAÇÃO OCULAR NO SISTEMA VISUAL DE RATOS}

Tese apresentada ao Programa de Pós- Graduação em Fisiologia e Biofísica do Instituto de Ciências Biomédicas da Universidade de São Paulo, para obtenção do Título de Doutor em Ciências.

Área de concentração: Fisiologia Humana

Orientador: Prof. Dr. Luiz Roberto Giorgetti de Britto

São Paulo

2011 
DADOS DE CATALOGAÇÃO NA PUBLICAÇÃO (CIP) Serviço de Biblioteca e Informação Biomédica do Instituto de Ciências Biomédicas da Universidade de São Paulo

Hernandes, Marina Sorrentino.

Geração de espécies reativas de oxigênio e neuroinflamação induzidas por enucleação ocular no sistema visual de ratos / Marina Sorrentino Hernandes. -- São Paulo, 2011.

Orientador: Luiz Roberto Giorgetti de Britto.

Tese (Doutorado) - Universidade de São Paulo. Instituto de Ciências Biomédicas. Departamento de Fisiologia e Biofísica. Área de concentração: Fisiologia Humana. Linha de pesquisa: Neurofisiologia.

Versão do título para o inglês: Reactive oxygen species generation and neuroinflammation induced by ocular enucleation in the rat visual system

Descritores: 1. Sistema visual 2. NADPH oxidase 3. Espécies reativas de oxigênio 4. Apocinina 5. NF-KB 6. Células da glia I. Britto, Luiz Roberto Giorgetti de II. Universidade de São Paulo. Instituto de Ciências Biomédicas. Programa de Pós-Graduação em Fisiologia Humana III. Título. 


\title{
UNIVERSIDADE DE SÃO PAULO INSTITUTO DE CIÊNCIAS BIOMÉDICAS
}

\begin{abstract}
Candidato(a): $\quad$ Marina Sorrentino Hernandes.
Título da Tese: Geração de espécies reativas de oxigênio e neuroinflamação induzidas por enucleação ocular no sistema visual de ratos.
\end{abstract}

Orientador(a): $\quad$ Luiz Roberto Giorgetti de Britto.

A Comissão Julgadora dos trabalhos de Defesa da Tese de Doutorado, em sessão pública realizada a , considerou

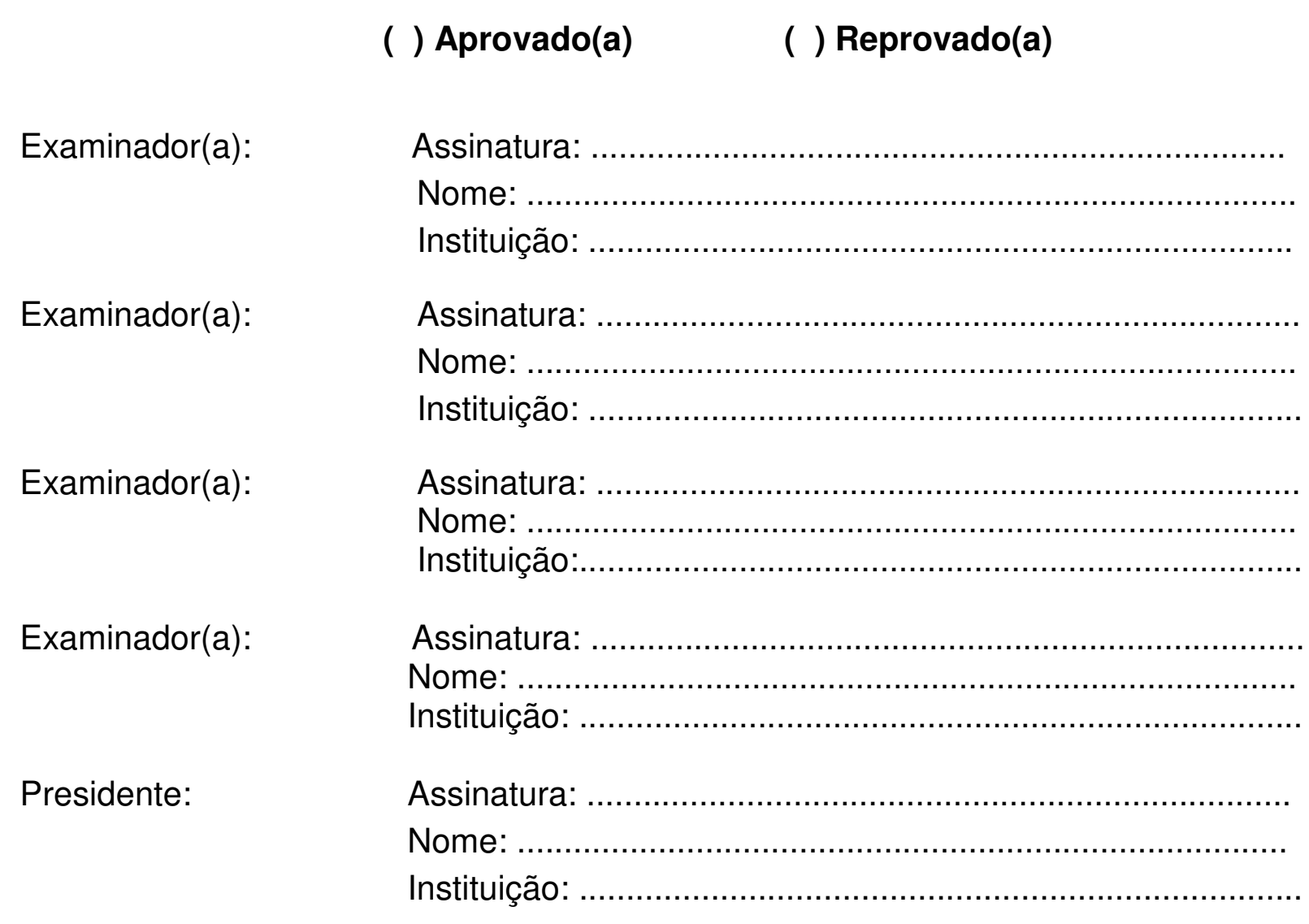




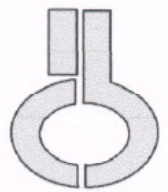

\section{Certificado}

Certificamos que o protocolo registrado sob $\mathrm{n}^{\circ} \mathbf{0 1 7}$ nas fls. 42 do livro 2 para uso de animais em experimentação, sob a responsabilidade de Luiz Roberto G. Britto Coordenador(a) da Linha de pesquisa "Neurodegeneração e geração de espécies reativas de oxigênio no sistema visual: estudo em um modelo de enucleação ocular em ratos" do qual participou(aram) o(s) alunos Marina Sorrentino Hernandes e a pesquisadora Lúcia Rossetti Lopes, está de acordo com os Principios Éticos de Experimentação Animal adotado pelo Colégio Brasileiro de Experimentação Animal (COBEA) e foi aprovado pela COMISSÃO DE ÉTICA EM EXPERIMENTAÇÃO ANIMAL (CEEA) em 27.02.2007.

São Paulo, 27 de fevereiro de 2007.

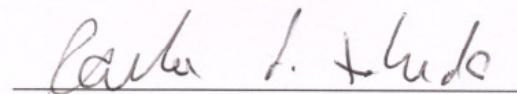

Prof. Dr. Carlos Pelleschi Taborda Vice - Coordenador da CEEA - ICB/USP

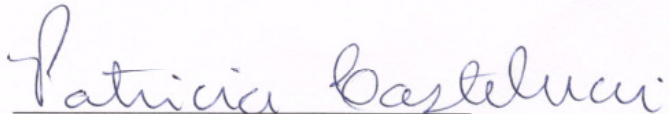

Profa. Dra. PATRÍCIA CASTELUCCI

Secretária da CEEA - ICB/USP 
Ao Narciso e ao Bruno, pelo amor e compreensão Aos mens pais, João e Silvia, pelo apoí carinhoso 


\section{AGRADECIMENTOS}

Ao meu orientador, Prof. Luiz Roberto G. Britto, com quem pude contar em todos momentos ao longo destes anos, pela ajuda inestimável durante a execução deste trabalho, pelos ensinamentos e por acreditar em mim sempre.

À minha co-orientadora, Profa. Lucia R. Lopes, por ter me recebido em seu laboratório, por todos os ensinamentos e direcionamentos, os quais tornaram possível este trabalho.

Ao Prof. Dr. Cristoforo Scavone, pela colaboração e auxílio prestados durante o desenvolvimento do trabalho.

À Larissa S. Lima, pela amizade e pelo auxílio na realização dos experimentos.

Ao Daniel O. Martins pela amizade e ajuda inestimável.

Aos colegas e amigos do laboratório de Neurobiologia Celular, pelo clima tão agradável, pelas discussões cientificas e contribuições em diversos aspectos: Vivian, Paula, Ana, Cecília, Rafaela, Erika, Carol Alencar, Mauro, Angélica, Taisa, Caio e Luciana.

Ao Adílson S. Alves pelo auxílio na execução dos experimentos; além de toda a atenção dispensada em pequenos detalhes diários que são bastante preciosos.

À Rosana L. Pagano, grande amiga, sua presença no laboratório tornou meus dias muito mais alegres, além de ter papel fundamental em meu desenvolvimento profissional. Obrigada pelas conversas instigantes e provocativas. 
À Carol C. Real por me acompanhar e me auxiliar na execução de diversos experimentos. Meus dias foram mais agradáveis com você do meu lado.

À Gabi P. Chaves, presença tão marcante e amiga, por toda ajuda e pelos diversos momentos de descontração.

À Kallene S. Vidal, pela amizade e por toda ajuda na discussão de meus resultados.

À Ana Maria Peracoli Campos, grande amiga, pelas conversas tão agradáveis e pelo auxílio na realização dos experimentos de imuno-histoquímica.

Ao Sidney Verissimo Filho por todo auxílio na realização dos experimentos com DHE, além de toda ajuda na montagem das imagens deste trabalho.

À Profa. Maria Helena Catelli de Carvalho e a Rosangela Eichler por tornarem este trabalho possível ao colaborarem na execução dos experimentos de RT-PCR. 
Este trabalho contou com o apoio financeiro da Fundação de Amparo à Pesquisa do Estado de São Paulo (FAPESP processo $n^{\circ}$ 06/60982-8), do Conselho Nacional de Desenvolvimento Científico e Tecnológico (CNPq) e da Coordenação de Aperfeiçoamento Pessoal de Nível Superior (CAPES). 
“Há um tempo em que é preciso abandonar as roupas usadas, que já tem a forma do nosso corpo, e esquecer os nossos caminhos, que nos levam sempre aos mesmos lugares. $E$ o tempo da travessia e, se não ousarmos fazê-la, teremos ficado, para sempre, à margem de nós mesmos"

Fernando Pessoa 


\section{RESUMO}

HERNANDES, M. S. Geração de espécies reativas de oxigênio e neuroinflamação induzidas por enucleação ocular no sistema visual de ratos. 2011. 155 f. Tese (Doutorado em Fisiologia e Biofísica) - Instituto de Ciências Biomédicas, Universidade de São Paulo, São Paulo, 2011.

O modelo de enucleação ocular em roedores é frequentemente empregado para 0 estudo dos efeitos da desaferentação de estruturas retinorrecipientes. Na primeira parte deste trabalho, avaliamos a geração de espécies reativas de oxigênio (EROs), nas estruturas retinorrecipientes colículo superior (CS) e núcleo geniculado lateral dorsal do tálamo (GLD) após enucleação ocular. A oxidação da dihidroetidina revelou o aumento da geração de EROs no CS e no GLD após a lesão. Os inibidores da NADPH oxidase, DPI e apocinina, foram capazes de inibir este aumento. Os resultados de RT-PCR revelaram aumento da expressão gênica de Nox 2 em ambas as estruturas avaliadas. Em contrapartida, observou-se aumento da expressão gênica de Nox 1 e 4 apenas no CS. Com a finalidade de avaliarmos o envolvimento de EROs no remodelamento estrutural após a lesão, animais foram tratados com apocinina e ensaios de imuno-histoquímica foram realizados utilizando-se anticorpos contra neurofilamentos (NFs) e proteínas associadas a microtúbulos-2 (MAP-2). Os resultados revelaram que a enucleação ocular produz um aumento na imunorreatividade para NFs e MAP-2 no CS e GLD, o que foi atenuado pelo tratamento com apocinina. Na segunda parte deste estudo, avaliamos a hipótese de que a enucleação ocular possa desencadear uma resposta inflamatória no CS. Observamos o aumento transiente da expressão proteica da proteína fibrilar acídica glial (GFAP) e de microglia após a lesão. Ensaios de gel de retardo para detectar a ativação do fator nuclear KB (NF-KB) indicam que este fator de transcrição foi ativado no SC nos períodos de 1 hora a 15 dias pós-lesão. A ativação do NF-KB ocorre concomitantemente ao aumento da transcrição gênica de ciclooxigenase-2, que é um gene responsivo à ativação deste fator de transcrição. Além disso, a ação do antiinflamatório dexametasona (DEX) foi avaliada sobre a ativação do NF-KB e de células da glia. A ativação de astrócitos e de microglia, bem como a ativação do NFKB após a lesão foi significativamente reduzida pelo tratamento com DEX. Com base nos resultados obtidos neste trabalho, pode-se concluir que a enucleação ocular é capaz de promover mudanças plásticas no encéfalo de ratos adultos, como alterações de elementos estruturais de neurônios e de populações de células da glia. Demonstramos também que essas alterações podem ser influenciadas pelo tratamento com antioxidantes e com anti-inflamatórios.

Palavras-Chave: Sistema visual. Estresse oxidativo. NADPH oxidase. Apocinina, Dexametasona. Fator de transcrição kappa B. Células da glia. 


\section{ABSTRACT}

HERNANDES, M. S. Reactive oxygen species generation and neuroinflammation induced by ocular enucleation in the rat visual system. 2011.155 p. Ph.D. Thesis (Human Physiology) - Instituto de Ciências Biomédicas, Universidade de São Paulo, São Paulo, 2011.

Unilateral ocular enucleation represents a useful model to study visual system plasticity. In the first part of this thesis, we evaluated the reactive oxygen species (ROS) generation in the main visual relays of the mammalian brain, namely the superior colliculus (SC) and the dorsal lateral geniculate nucleus (DLG), after ocular enucleation. Dihydroethidium oxidation revealed increased ROS generation in SC and DLG. ROS generation was decreased by the Nox inhibitors DPI and apocynin. Real-time PCR results revealed that Nox 2 was upregulated in both retinorecipient structures after deafferentation, whereas Nox 1 and Nox 4 were upregulated only in the SC. To evaluate the role of ROS in structural remodeling after the lesions, apocynin was given to enucleated rats and immunohistochemistry was conducted for markers of neuronal remodeling into SC and DLG. Immunohistochemical data showed that ocular enucleation produces an increase of neurofilament and microtubule-associated protein-2 immunostaining in both SC and DLG, which was markedly attenuated by apocynin treatment. In the second part of the study, we focused on the hypothesis that the deafferentation of visual system may generate inflammatory-mediated responses in the SC. We first observed that glial cells protein expression is markedly increased after the lesion. Electrophoretic mobility shift assays (EMSA) to detect nuclear factor ${ }_{k} \mathrm{~B}\left(\mathrm{NF}_{-\mathrm{k}} \mathrm{B}\right)$ activation indicated that this transcription factor is activated in the SC from 1 hour to day 15 after the lesion. These periods approximately coincided with the increased expression of cyclooxygenase-2, which is a target gene for $\mathrm{NF}_{-\mathrm{k}} \mathrm{B}$. To evaluate the role of an antiinflammatory drug in attenuating both $\mathrm{NF}-{ }_{\mathrm{s}} \mathrm{B}$ and glial cells activation, the glucocorticoid dexamethasone (DEX) was administered (1 mg/kg i.p., for 3 days) to enucleated rats and immunohistochemistry was performed to detect markers of astrocytes and microglia activation. The immunostaining revealed increased astrocyte and microglia proliferation after the lesion, which was significantly reduced by the DEX treatment. Similarly, NF- ${ }_{\mathrm{B}} \mathrm{B}$ activation was attenuated by DEX treatment. Taken together, the findings of the present study suggest a novel role for Noxinduced ROS signaling in mediating neuronal remodeling in visual areas after ocular enucleation. Moreover, these results raise the possibility that the removal of retinal ganglion cell input generates inflammatory responses in the SC.

Key words: Visual system. Oxidative stress. NADPH oxidase. Apocynin, Dexamethasone. Nuclear factor kappa B. Glial cells. 


\section{LISTA DE ABREVIATURAS E SIGLAS}

7- NI - 7-nitroindazol

ANOVA - Análise de variância

ATP - Trifosfato de adenosina

CEEA - Comissão de ética em experimentação animal

CGL - Complexo geniculado lateral do tálamo

COX-2 - Ciclooxigenase-2

CREB - Proteína de ligação ao elemento de resposta ao AMP cíclico

CS - Colículo superior

DAB - Diaminobenzidina

DCF-DA - Diacetato de dichlorodihidrofluoresceína

DEPC - Água tratada com dietil-pirocarbonato

DEX - Dexametasona

DHE - Dihidroetidina

DNA - Ácido desoxirribonucleio

dNTPs - Trifosfato de desoxinucleotídeos

DP - Doença de Parkinson

DPI - Diphenylene iodonium

DTPA - Ácido dietilenotriaminopentaacético

DTT - Ditiotreitol

ECL - Sistema de detecção de quimioluminescência

EDTA - Ácido etilenodiaminotetracético 
EMSA - Ensaio de gel de retardo para NF-кB

EOH - 2-hidroxietídio

ERK1/2 - Quinases 1 e 2 reguladas por sinais extracelulares

ERK5 - Quinase 5 regulada por sinais extracelulares

ERNs - Espécies reativas de nitrogênio

EROs - Espécies reativas de oxigênio

FITC - Isotiocianato de fluoresceína

GAPDH - Gliceraldeído 3-fosfato desidrogenase

GFAP - Proteína fiblilar acídica glial

GLD - Núcleo geniculado lateral dorsal do tálamo

GLV - Núcleo geniculado lateral ventral do tálamo

HIF-1alpha - Fator induzido por hipóxia alfa

HRP - Peroxidase extraída de raiz forte

IGL - Núcleo intergeniculado do tálamo

IкBs - Proteínas inibidoras do NF-кB

JNK - Quinase N-terminal de cJun

L-DOPA - Levodopa

MAP- quinases - Quinases associadas à mitógenos

MAP-2 - Proteínas associadas ao microtúbulo 2

NADPH oxidase - Nicotinamida adenina dinucleotídeo fosfato oxidase

NFs - Neurofilamentos

NF-KB - Fator nuclear kappa B

nNOS - Enzima sintase do óxido nítrico 


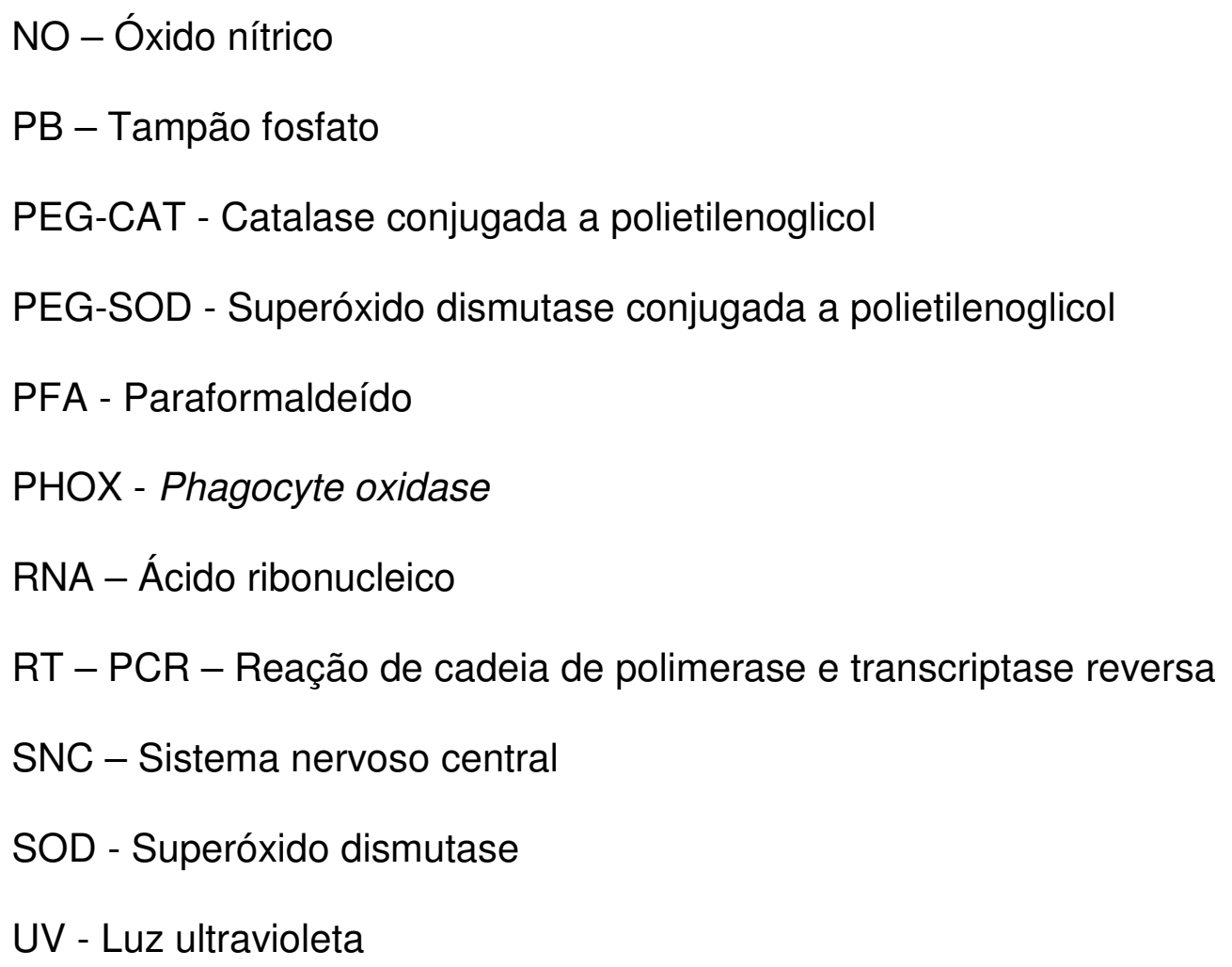




\section{SUMÁRIO}

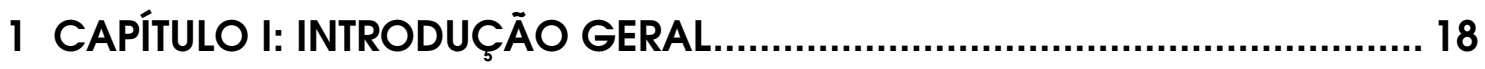

1.1 ORGANIZAÇÃO FUNCIONAL GERAL DO SISTEMA VISUAL .............................. 18

1.2 ENUCLEAÇÃO OCULAR ............................................................... 21

2 CAPÍTULO II: GERAÇĀO DE ESPÉCIES REATIVAS DE OXIGÊNIO NO SISTEMA VISUAL APÓS ENUCLEAÇÃO OCULAR. .................................................... 23

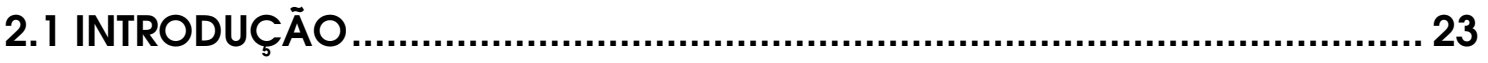

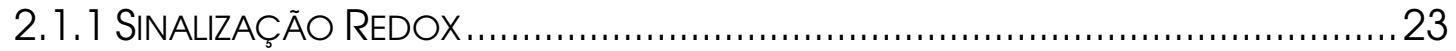

2.1.2 ESTRESSE OXIDATIVO E O ENVOLVIMENTO DAS EROS NA FISIOPATOLOGIA DE DOENÇAS

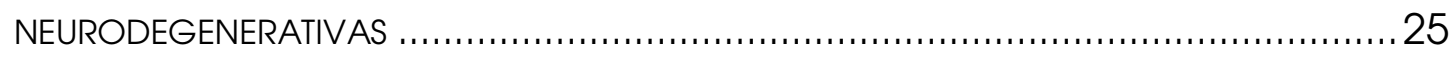

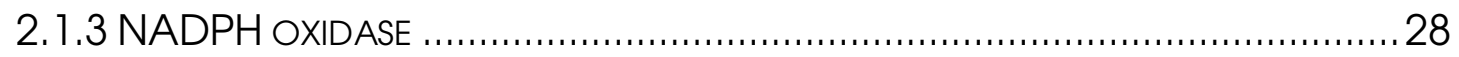

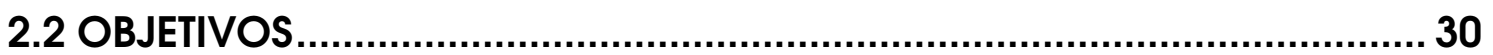

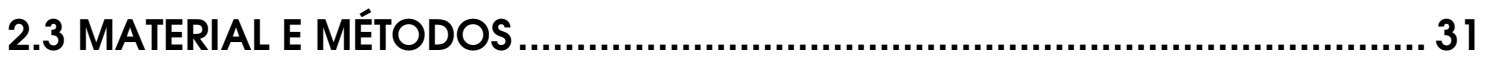

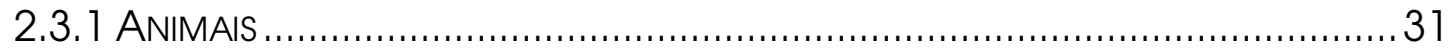

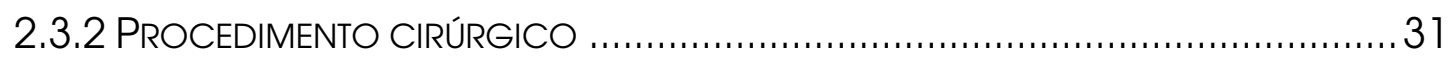

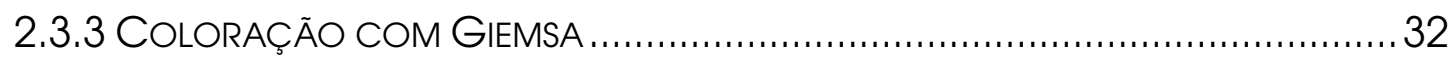

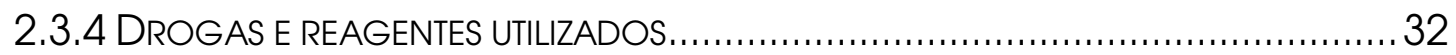

2.3.5 ANÁLISE DA FLUORESCÊNCIA DERIVADA DOS PRODUTOS DE OXIDAÇÃO DA DIHIDROETIDINA EM CORTES HISTOLÓGICOS .................................................... 33

2.3.6 QUANTIFICAÇÃO DE MRNA POR REAL-TIME PCR (RT - PCR) ...................... 34

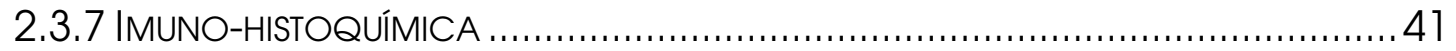

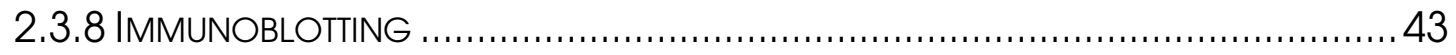

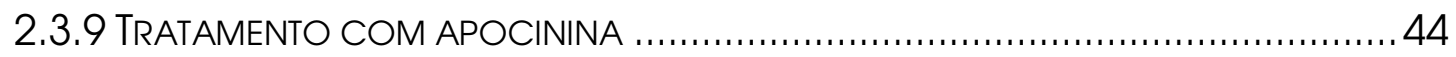

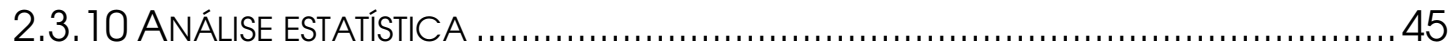

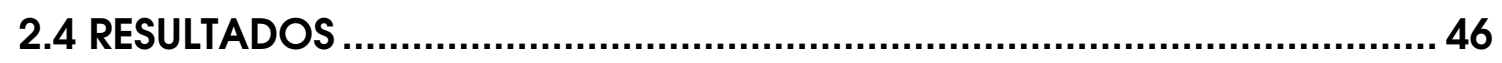

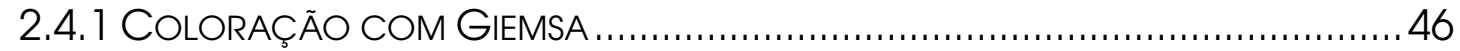

2.4.2 DETERMINAÇÃO DOS GRUPOS CONTROLES ...............................................46

2.4.3 ANÁLISE DA FLUORESCÊNCIA DERIVADA DOS PRODUTOS DE OXIDAÇÃO DA

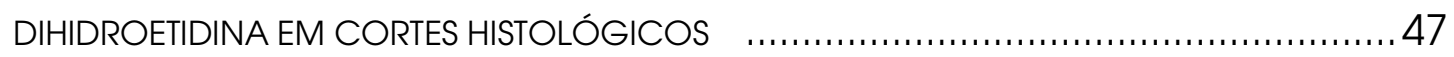

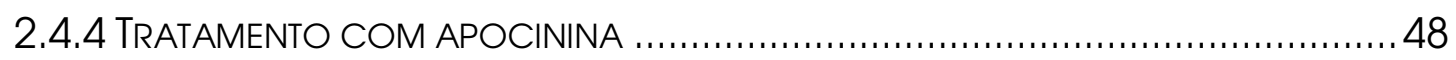

2.4.5 QUANTIFICAÇÃO DE MRNA POR REAL-TIME PCR …....................................48

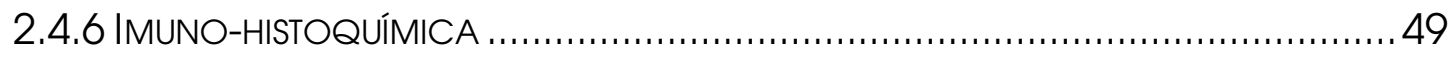




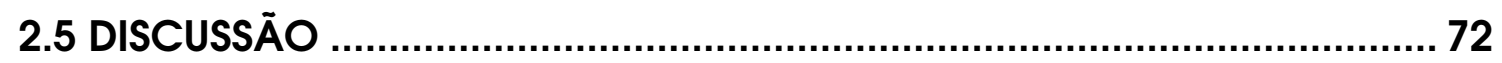

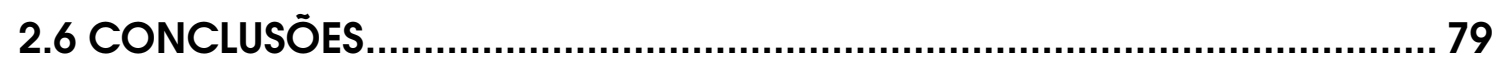

3 CAPÍTULO III: ATIVAÇÃO DE CÉLULAS DA GLIA E DO FATOR DE TRANSCRIÇÃO NF-KB INDUZIDOS POR ENUCLEAÇÃO OCULAR.......................................... 80

3.1 INTRODUÇÃO

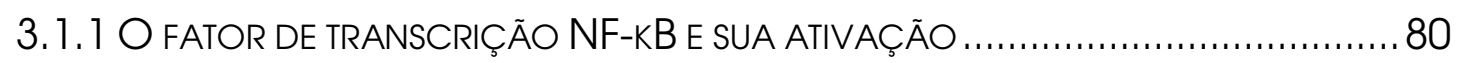

3.1.2 CÉLULAS GLIAIS: ASPECTOS GERAIS................................................... 82

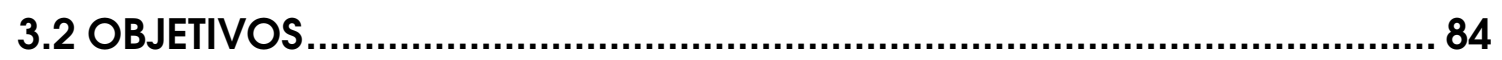

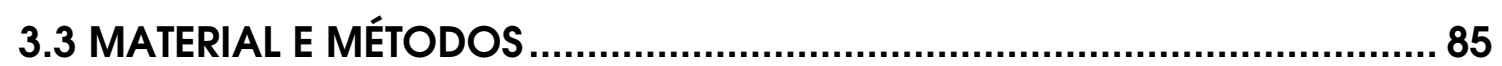

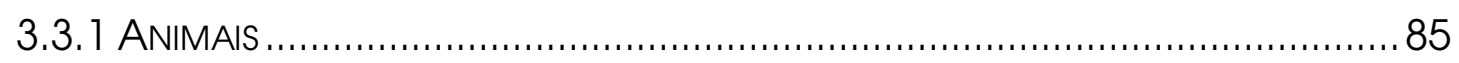

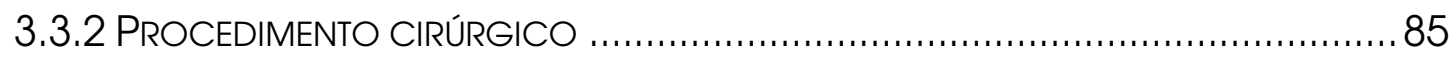

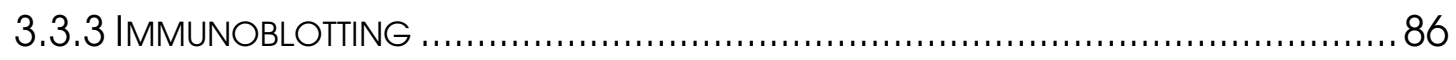

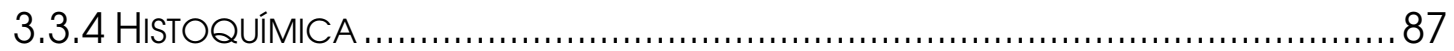

3.3.5 ENSAIO DE GEL DE RETARDO (ELECTROPHORETIC MOBILITY GEL SHIFT ASSAYEMSA) PARA

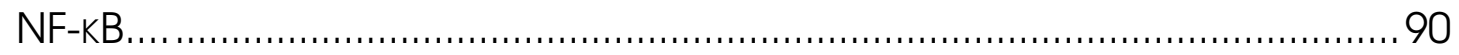

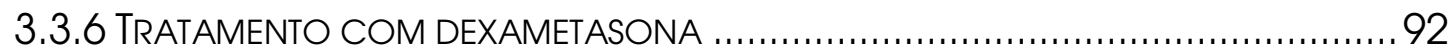

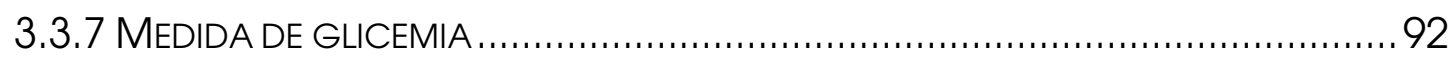

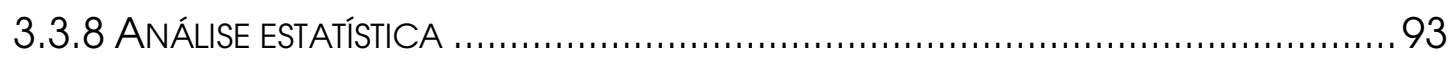

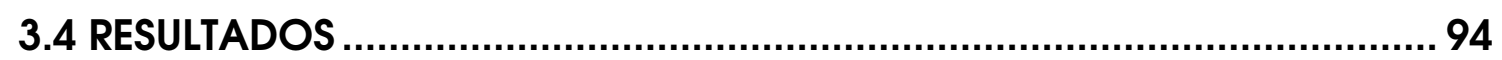

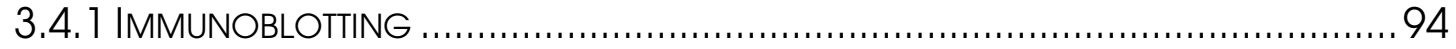

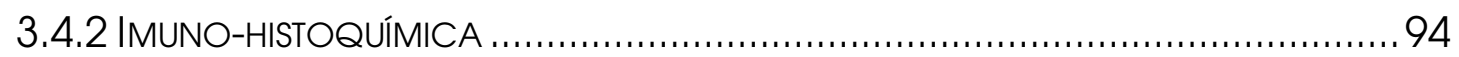

3.4.3 ENSAIO DE GEL DE RETARDO PARA NF-KB …......................................... 95

3.4.4 MEDIDA DE GLICEMIA ................................................................... 95

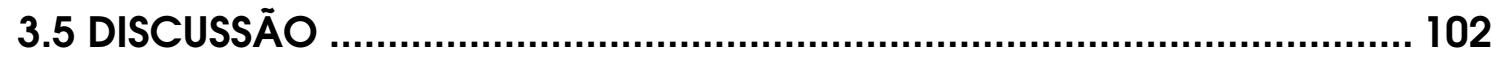

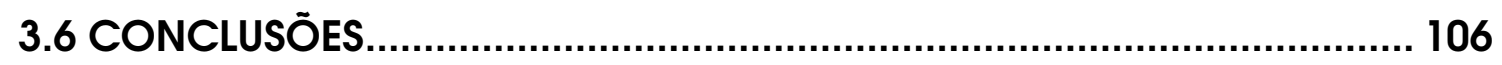

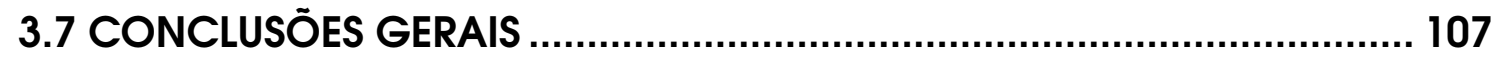

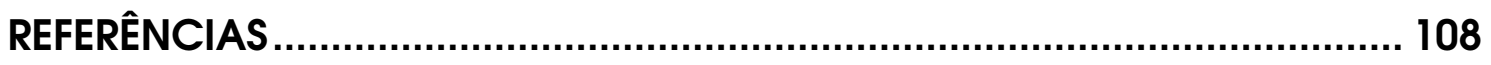

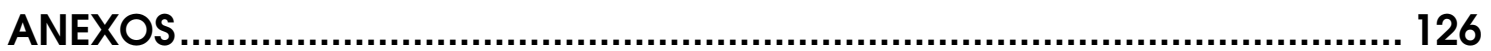

ANEXO A - TRABALHO PUBLICADO NO PERIÓDICO NEUROSCIENCE...... 127 
ANEXO B - TRABALHO SUBMETIDO PARA PUBLICAÇÃO NO PERIÓDICO JOURNAL OF NEUROSCIENCE RESEARCH. 


\section{CAPÍTULO I: INTRODUÇÃO GERAL}

\subsection{Organização funcional geral do sistema visual}

A retina é uma das estruturas do sistema nervoso mais estudadas em função de sua arquitetura organizada em camadas celulares e plexiformes (LINDEN e PERRY, 1983). As interações entre os diferentes tipos celulares que a constituem, além de sua morfologia, foram determinadas ao longo de muitos anos de estudos empregando-se uma grande variedade de técnicas experimentais tais como microscopia eletrônica, microscopia de contraste interferencial, coloração de Nissl e coloração de Golgi (RAMON e CAJAL, 1972; JEON et al., 1998; TSUKAMOTO et al., 2001).

O processamento da visão inicia-se em fotorreceptores, cones e bastonetes, através dos quais a energia luminosa é transformada em sinal elétrico. Este processo, também conhecido como fototransdução, é seguido por uma via vertical de neurotransmissão excitatória pela qual os sinais gerados nos fotorreceptores são tansmitidos para células bipolares e, em seguida, para as células ganglionares. Além disso, por uma via de transmissão indireta, sinais são transmitidos de células bipolares para células ganglionares por intermédio de células amácrinas. Existem também vias laterais de inibição, as quais são capazes de modular a via vertical de neurotransmissão excitatória (CHALUPA e WILLIAMS, 2008). Diversos outros sistemas são capazes de modular a função retiniana, como, por exemplo, o sistema dopaminérgico de controle de adaptação à luz (WEILER et al., 2000), gap junctions, além de D-serina (MILLER, 2004).

As células ganglionares da retina formam as eferências retinianas para os vários núcleos que compõem o sistema visual. Suas projeções constituem o nervo óptico e posteriormente o quiasma e o trato óptico (CHALUPA e WILLIAMS, 2008). Em mamíferos, a grande maioria das células ganglionares se projeta para núcleos retinorrecipientes contralaterais. A porcentagem de fibras que trafegam ipsolateralmente varia consideravelmente de acordo com a espécie e está 
intimamente relacionada com o posicionamento dos olhos no crânio. Em espécies com olhos posicionados lateralmente as projeções ipsolaterais tendem a ser menores. Em ratos, de 3 a $5 \%$ das projeções retinianas são ipsolaterais (JEFFERY, 1984; DREHER et al., 1985). Em contrapartida, em gatos as projeções ipsolaterais totalizam de 25 a $30 \%$ das fibras e, em macacos, este numero pode chegar a $40 \%$ (TASSINARI et al., 1997; CHALUPA e LIA, 1991).

Entre os núcleos retinorrecipientes podemos citar o colículo superior (CS), o complexo geniculado lateral do tálamo (CGL), o núcleo supraquiasmático do hipotálamo, além de diversos núcleos do complexo pré-tectal. Interessantemente e a despeito do que ocorre em outras estruturas, os neurônios do núcleo supraquiasmático recebem aferências excitatórias de células ganglionares de ambas as retinas, contralateral e ipsolateral, em proporções similares (ABRAHAMSON e MOORE, 2001).

Contudo, o CS é a estrutura do mesencéfalo que recebe a maioria maciça das projeções retinianas (LINDEN e PERRY, 1983; CHALUPA e WILLIAMS, 2008). Em todos os mamíferos, incluindo o rato, sete camadas celulares distintas podem ser visualizadas no CS. As três camadas mais superficiais do CS, zona marginal ou stratum zonale, camada cinzenta superficial ou stratum griseum superficiale e camada óptica ou stratum opticum, recebem a grande maioria das projeções retinianas (LINDEN e PERRY, 1983; PAXINOS e WATSON, 2005), além de projeções do córtex visual ipsolateral (LUND et al., 1976). Os neurônios destas camadas projetam seus axônios para camadas intermediárias (camada cinzenta intermediária ou stratum griseum intermediale e camada branca intermediária ou stratum álbum intermediale) e camadas profundas do CS (camada cinzenta profunda ou stratum griseum profundum e camada branca profunda ou stratum album profundum), nas quais ocorre a convergência de informações visuais, auditivas e sômato-sensoriais (HARTING et al., 1973; BE, 1981). Em ratos adultos, as projeções retinianas ipsolaterais são restritas às camadas cinzenta superficial e óptica das regiões rostrais e mediais do CS (HAYHOW, 1962; GODEMENT et al., 1984). De maneira geral, o CS de ratos influencia a navegação e orientação espacial dos 
movimentos, a direção e velocidade dos movimentos dos olhos (MCHAFFIE e STEIN, 1982; OKADA, 1992), bem como a orientação aos estímulos visuais para defesa, esquiva e/ou reações de escape (OLDS e OLDS, 1962; GOODALE et al., 1978; REDGRAVE et al., 1981; KING, 1999).

O CGL está relacionado com o processamento de respostas circadianas a luz, além de, juntamente com o núcleo olivar pré-tectal, estar envolvido com o processamento dos reflexos pupilares à luz (SEFTON, 2004). Os neurônios do CGL recebem aferências contra e ipsolaterais do CS (NAUTA e VAN STRAATEN, 1947; HAYHOW, 1962), de algumas regiões subcorticais, e projeções corticais oriundas principalmente da camada $\mathrm{VI}$ dos córtices visuais primário e secundário (MASON e GROOS, 1981; TAKAHASHI, 1985). O CGL é dividido em três estruturas: núcleo geniculado lateral dorsal (GLD), núcleo geniculado lateral ventral (GLV) e núcleo intergeniculado (IGL). O GLD situa-se na região dorso-lateral do tálamo dorsal e todas as suas eferências são ipsolaterais. Estas eferências são distribuídas entre o córtex visual primário (LASHLEY, 1934), o córtex visual secundário medial e lateral (RIBAK e PETERS, 1975; PERRY, 1980) e o núcleo reticular do tálamo. A maior fonte de estímulos visuais ao córtex origina-se do GLD (COLEMAN e CLERICI, 1980; SEFTON et al., 1981). Interessantemente, muito embora apenas de 3 a $5 \%$ das projeções retinianas trafeguem ipsolateralmente, tais projeções ocupam de 14 a $18 \%$ da região dorsomedial do GLD (GODEMENT et al., 1984). O GLV está situado na região ventral do tálamo (JONES e YANG, 1985). Duas regiões podem ser observadas no GLV, uma lateral denominada magnocelular e uma medial conhecida como parvocelular, sendo que apenas a região magnocelular recebe aferências retinianas provenientes de ambos os olhos (CAJAL, 1911; HICKEY e SPEAR, 1976). Entre ○ GLV e o GLD existe uma estreita lâmina, o IGL. De maneira geral, as eferências do GLV projetam-se predominantemente para regiões visuais e, as eferências do IGL para o hipotálamo e também para algumas regiões visuais, incluindo o núcleo supraquiasmático (MOORE et al., 2000). 


\subsection{Enucleação ocular}

O modelo de enucleação ocular em roedores é frequentemente empregado para o estudo dos efeitos da desaferentação de estruturas retinorrecipientes. Neste sentido, alguns trabalhos discutem o impacto da enucleação ocular no CGL. Zirpel e colaboradores, por exemplo, demonstraram que os níveis de cálcio intracelular no CGL aumentam após a enucleação ocular (ZIRPEL et al., 1995). Em contrapartida, de 12 a 14 dias após a lesão observou-se 15\% de diminuição da concentração de glutamato nesta estrutura por meio da utilização de ensaios enzimáticos (SAKURAI e OKADA, 1992). Cinco dias após a lesão, o binding de serotonina triciada foi reduzido em 33\% (CHALMERS e MCCULLOCH, 1991). Este núcleo também parece ser a estação visual mais afetada após privação monocular ( $\mathrm{NUCCl}$ et al., 2002). Em adição, Wiesel e Hubel em 1963 foram os primeiros a mostrar que, no CGL de gatos jovens, o diâmetro das células diminui após este tipo de privação; em ratos recémnascidos, ocorre uma elevada perda celular (WIESEL e HUBEL, 1963; NUCCl et al., 2002).

Lane e colaboradores também descreveram, desta vez no CS de ratos, um aumento na expressão de proteínas ligantes de cálcio, como a calbindina e a parvalbumina, após desaferentação retiniana. Em ratos neonatos, tais alterações não foram encontradas (LANE et al., 1996). A concentração de glutamato e a expressão de receptores de glutamato do tipo AMPA também foram significantemente reduzidas no CS após a enucleação ocular (SAKURAI e OKADA, 1992; KIM e JEON, 1999). Estudos realizados por nosso grupo de pesquisa revelaram que após enucleação ocular há um aumento na expressão da enzima sintase do óxido nítrico (nNOS) em regiões específicas do CS e do CGL de ratos adultos. No entanto, a significância funcional deste fato permanece desconhecida, visto que o óxido nítrico (NO) parece estar envolvido em mecanismos tanto de neuroproteção quanto de neurotoxicidade (CHACUR et al., 2006).

Considerando as inúmeras evidências do importante papel sinalizador mediado por espécies reativas, a elucidação de processos que envolvem a produção 
destas espécies pode contribuir para o entendimento de mecanismos de plasticidade neuronal decorrentes de lesões no sistema visual de ratos. Tais investigações foram conduzidas e discutidas no Capítulo II desta tese.

No Capítulo III demonstramos que a enucleação ocular pode promover alterações nas populações de astrócitos e de microglia, além de levar a ativação de um fator de transcrição no CS. Investigamos também como tais alterações podem ser afetadas pelo tratamento com o glicocorticóide dexametasona (DEX). 


\section{CAPÍTULO II: GERAÇÃO DE ESPÉCIES REATIVAS DE OXIGÊNIO NO SISTEMA VISUAL APÓS ENUCLEAÇÃO OCULAR}

\subsection{INTRODUÇÃO}

\subsubsection{Sinalização Redox}

A sinalização redox pode ser definida como a transdução de sinais celulares na qual o elemento integrativo é uma série de reações de transferência de elétrons interconectadas envolvendo espécies reativas de oxigênio (EROs), equivalentes redutores e/ou espécies relacionadas (GO et al., 2004).

EROs são formadas a partir de processos de oxidação e redução (FRIDOVICH, 1997). A redução do oxigênio na presença de um elétron livre gera ânion superóxido $\left(\mathrm{O}_{2^{\bullet-}}\right)$, que é um radical instável e, devido a sua carga, incapaz de atravessar membranas celulares. $\mathrm{O} \mathrm{O}_{2}{ }^{\bullet-}$ pode agir como um agente oxidante, sendo reduzido a peróxido de hidrogênio $\left(\mathrm{H}_{2} \mathrm{O}_{2}\right)$, ou como agente redutor, formando peroxinitrito (ONOO`), que também é uma ERO (DARLEY-USMAR et al., 1995). O $\mathrm{H}_{2} \mathrm{O}_{2}$ é uma espécie não radicalar, lipossolúvel, que possui meia vida maior que a do seu precursor, $0 \mathrm{O}_{2} \cdot-$. $\mathrm{O} \mathrm{H}_{2} \mathrm{O}_{2}$ pode ser formado espontaneamente pela dismutação do $\mathrm{O}_{2}{ }^{\bullet-}$, mas esta reação também pode ser catalisada pela enzima superóxido dismutase (SOD) (FRIDOVICH, 1997; CHANNON e GUZIK, 2002). Diferentemente das outras EROs, o $\mathrm{O}_{2} \bullet-$ e $\circ \mathrm{H}_{2} \mathrm{O}_{2}$ podem ter vida média suficientemente longa, de modo compatível com seu papel na sinalização redox celular.

Ao longo dos últimos anos, tornou-se evidente que a exposição de células a alterações moderadas na homeostase redox, também conhecida como estado redox, resulta na modulação de diversas vias de sinalização. Oxidantes podem ativar e inativar fatores de transcrição, canais de membrana, enzimas, regularem vias de sinalização dependentes de cálcio e de fosforilação, além de agirem como segundos mensageiros em resposta a estímulos definidos, alterando a atividade de organelas celulares (DROGE, 2002; KAMSLER e SEGAL, 2007). Estes processos constituem 
os maiores eventos regulatórios celulares, determinando que a oxidação e redução sejam capazes de modular a grande maioria dos aspectos da fisiologia celular (WINTERBOURN e HAMPTON, 2008).

De fato, sabe-se que EROs são importantes mediadores na diferenciação e crescimento celular, agindo como segundos mensageiros em algumas vias de sinalização, muito embora nem todas as moléculas-alvo tenham sido descritas. As EROs podem ativar MAP quinases tais como ERK1/2, p42MAP quinase, JNK e ERK5, que estão relacionadas a crescimento, diferenciação celular, inflamação e apoptose (TORRES, 2003). Em neurônios, EROs também podem induzir a transcrição do HIF-1alpha, um fator de transcrição envolvido de modo importante com a homeostase do oxigênio celular (SAZONTOVA et al., 2007). Alguns estudos sugerem o envolvimento de EROs no controle central da pressão arterial, por meio da ativação de vias de sinalização intracelulares que sabidamente interferem com a atividade de neurônios de regiões do tronco encefálico envolvidas no controle cardiovascular (PETERSON et al., 2006). Além disso, recentemente Hidalgo e colaboradores (HIDALGO et al., 2007) descreveram o envolvimento de EROs na plasticidade sináptica hipocampal. De acordo com os autores, EROs geradas pela reação de Fenton estimulam o receptor de rianodina, que medeia a liberação de cálcio intracelular. O cálcio, por sua vez, ativa cascatas de sinalização que levam à transcrição de genes que participam da plasticidade sináptica. 


\subsubsection{Estresse oxidativo e o envolvimento das EROs na fisiopatologia de doenças neurodegenerativas}

O ambiente redox intracelular é constantemente controlado e mantido em estado redutor, a não ser que a célula seja exposta a situações oxidantes extremas. A homeostase redox é crucial para manter a atividade biológica e a geração adequada tanto de EROs quanto ERNs (espécies reativas de nitrogênio) (SCHAFER e BUETTNER, 2001).

Em 1985 Helmut Sies definiu estresse oxidativo como um desequilíbrio celular entre mecanismos antioxidantes (como SODs e tioredoxinas) e mecanismos pró-oxidantes (sistemas geradores de EROs). De acordo com esta definição, o termo estresse oxidativo referiria-se, portanto, à citotoxicidade mediada por EROs (POON et al., 2004). Contudo, evidências recentes sugerem que o desequilíbrio entre os sistemas pró e antioxidantes ocorre em fases mais tardias de patologias (GUZIK e HARRISON, 2006). Em estágios iniciais, alterações na geração de EROs restringemse a compartimentos celulares específicos como endossomos, cavéolas, núcleos e não implicam necessariamente na alteração do estado redox global da célula (GO et al., 2004). Assim, a idéia do desequilíbrio entre fatores oxidantes e antioxidantes para explicar o estresse oxidativo, embora ainda seja válida para explicar a modulação da concentração de EROs no organismo, atualmente está sendo substituída por uma visão mais complexa e elaborada de que alterações no fluxo de elétrons em determinados sistemas enzimáticos resultariam na formação excessiva e patológica de intermediários de vias de sinalização redox, desencadeando o estresse oxidativo (JONES, 2006). O estresse oxidativo, por sua vez, pode ativar circuitos patológicos, o que resultaria não apenas em dano radicalar a biomoléculas, como também em um quadro de inflamação, além de aumento na proliferação, migração e remodelamento da matriz celular (JONES, 2006; OHARA, 2006).

Neurônios são susceptíveis ao estresse causado por EROs e ERNs, incluindo o NO. EROs têm a capacidade de oxidar proteínas, lipídios e ácidos nucléicos e, como conseqüência, prejudicar a sua função fisiológica (KUME et al., 
2004). O tecido nervoso parece ser especialmente susceptível ao dano oxidativo por possuir altas taxas metabólicas, por sua reduzida capacidade de regeneração celular e por sua reduzida capacidade antioxidante, em comparação com outros tecidos (FLOYD, 1999; ANDERSEN, 2004). De fato, a presença de agentes antioxidantes no tecido cerebral é modesta. Os níveis de catalase (enzima que catalisa a formação de $\mathrm{H}_{2} \mathrm{O}$ e $\mathrm{O}_{2}$ a partir do $\mathrm{H}_{2} \mathrm{O}_{2}$ ), por exemplo, são baixos no hipotálamo e na substância negra, e ainda menores no cerebelo e no córtex (HALLIWELL, 2001).

Algumas linhas de investigação procuram elucidar o papel do estresse oxidativo em distúrbios neurodegenerativos, visto que, nestas circunstâncias, observa-se o aumento da formação de EROs e de ERNs (FLOYD, 1999). Em pacientes diagnosticados com esclerose múltipla, por exemplo, a oxidação do DNA e do DNA mitocondrial parece ser mediada por células mononucleares ativadas, as quais produzem grandes quantidades de EROs (VLADIMIROVA et al., 1999; LU et al., 2000).

A análise do tecido cerebral postmortem de pacientes com doenças neurodegenerativas como a doença de Parkinson (DP), o mal de Alzheimer e a esclerose lateral amiotrófica revelam claramente o excesso de produção de EROs nas regiões cerebrais mais afetadas pela doença. Indícios de peroxidação lipídica, por exemplo, foram identificados no córtex cerebral e no hipocampo de indivíduos com o mal de Alzheimer, e na substância negra de indivíduos acometidos pela DP (DEXTER et al., 1989; HENSLEY et al., 1998; PEDERSEN et al., 1998). Considerando especificamente a DP, o estresse oxidativo é considerado um mecanismo primário de indução da morte de células dopaminérgicas. O sistema nigro-estriatal parece ser especialmente vulnerável ao estresse oxidativo por vários fatores, como (1) os altos níveis de ferro na substância negra e no globo pálido favorecem a formação do radical hidroxila, uma espécie capaz de reagir rapidamente com biomoléculas; e (2) a dopamina, assim como a L-DOPA, podem reagir com $\mathrm{O}_{2}$ gerando $\mathrm{O}_{2}^{-}-$, quinonas e semiquinonas, as quais são capazes de se ligarem a proteínas que contenham grupamentos $\mathrm{SH}$ como a glutationa. Neste sentido, avaliações do tecido cerebral post mortem revelaram aumento nos níveis de 
peroxidação lipídica, oxidação de proteínas e DNA, além de diminuição nos níveis de glutationa na substância negra (SPENCER et al., 1998; HALLIWELL e WHITEMAN, 2004).

Em alguns casos, evidências apontam para o envolvimento de EROs na propagação do dano celular causado por diversas neuropatologias. No entanto, os indícios do aumento da produção de EROs não são conclusivos acerca de seu envolvimento na neurodegeneração, ou seja, não se sabe se EROs atuam como mediadores ou efetores finais de tais danos (ANDERSEN, 2004).

Assim como outros tipos celulares, os neurônios possuem sofisticados mecanismos de defesa e reparo contra o estresse e contra possíveis danos oxidativos. Agentes antioxidantes são moléculas capazes de decompor EROs. Os maiores grupos de agentes antioxidantes são moléculas com baixo peso molecular (vitaminas $\mathrm{C}$ e $\mathrm{E}$, e as ubiquinonas), enzimas antioxidantes, (SOD, superóxido redutase e catalase) e moléculas contendo grupos tióis (ARRIGO, 1999). Estas últimas são tão abundantes que o estado redox intracelular é reflexo dos níveis celulares de grupos tiol (sulfidrila) e dissulfetos, usualmente desviado para o lado redutor. Esta tendência redutora é dependente de um sistema tamponante majoritariamente composto pela glutationa (HWANG et al., 1992; MEISTER, 1992; SMITH et al., 1996).

Sabe-se que a atividade de algumas moléculas antioxidantes está reduzida em neuropatologias. Em regiões acometidas pelo mal de Alzheimer, a atividade de enzimas como a SOD, catalase, glutationa peroxidade e glutationa redutase encontra-se reduzida. Estudos postmortem do tecido cerebral de indivíduos acometidos pela DP também revelaram que, na substância negra, a atividade da enzima glutationa peroxidase está diminuída. Ou seja, a diminuição do potencial antioxidante pode consistentemente contribuir para o desequilíbrio redox celular, levando ao estresse oxidativo e à neurodegeneração (ZEMLAN et al., 1989; PAPPOLLA et al., 1992). Outros trabalhos também revelaram diminuição nos níveis de enzimas antioxidantes no sangue e no fluido cérebro-espinal de pacientes acometidos por esclerose múltipla (GRECO et al., 1999; FERRETTI et al., 2005). 


\subsubsection{NADPH oxidase}

A NADPH oxidase (nicotinamida adenina dinucleotídeo fosfato oxidase) foi inicialmente descrita em neutrófilos e posteriormente identificada em outros tipos celulares. A oxidase fagocítica é formada por múltiplos componentes, alguns citossólicos como o p47 $7^{\mathrm{PHOX}}$ (phagocyte oxidase), $\mathrm{p} 67^{\mathrm{PHOX}}$ e $\mathrm{p} 40^{\mathrm{PHOX}}$ e outros localizados na membrana, como gp91 ${ }^{\mathrm{PHOX}}$ e p22 ${ }^{\mathrm{PHOX}}$, que formam o heterodímero citocromo b558. Após estímulo, fosforilação e migração para a membrana dos componentes citosólicos ocorre a ativação da oxidase, que efetua a transferência de equivalentes redutores do NADPH para o oxigênio, gerando $\mathrm{O}_{2}{ }^{\bullet-}$. Além disso, o $\mathrm{H}_{2} \mathrm{O}_{2}$ pode ser gerado como produto secundário, através da dismutação do $\mathrm{O}_{2} \bullet$ - pela ação da SOD (BABIOR, 1999; LOPES et al., 1999; VIGNAIS, 2002).

A partir do início da década de 90 detectou-se a produção de pequenas quantidades de EROs, incluindo $\mathrm{O}_{2} \bullet-$, em tecidos vasculares e cardíacos. Porém, só em 1999 o primeiro homólogo da subunidade catalítica da NADPH oxidase (gp91 ${ }^{\mathrm{PHOX}}$ ) foi identificado e denominado Nox 2 (SUH et al., 1999). Hoje sabemos que o sistema vascular produz $\mathrm{O}_{2} \bullet$ - através de enzimas muito similares à NADPH oxidase fagocítica e que o gp91 ${ }^{\mathrm{PHOX}}$ é apenas um dos membros de uma nova família de proteínas homólogas chamadas de Nox presentes em diversos tecidos. Foram descritos até o momento sete membros da família NADPH oxidase, a saber, Nox 1-5 e DUOX1 e DUOX 2. O processo de ativação das isoformas do complexo NADPH oxidase tem sido intensamente investigado; estas isoformas dependem de diferentes subunidades regulatórias, e aparentemente apresentam diferentes perfis de ativação. $A$ ativação da isoforma Nox 2 requer sua interação com a p22 ${ }^{\text {PHOX }}$, com Rac 1 ou 2 , além da interação com as subunidades p4 $7^{\mathrm{PHOX}}, \mathrm{p} 67^{\mathrm{PHOX}}$ e $\mathrm{p} 40^{\mathrm{PHOX}}$. As isoformas Nox 1, Nox 3 e Nox 4 também estão associadas subunidade de membrana p22 ${ }^{\text {PHOX }}$, porém possuem mecanismos de ativação distintos. A ativação da isoforma Nox 1 requer sua interação com as subunidades citosólicas NOXA1 e NOXO1, além da interação com a Rac 1 ou 2. A Nox 3 interage com a NOXO1, porém sua interação com a NOXA1 ou com isoformas da Rac não foi descrita. Em contrapartida, a 
isoforma Nox 4 parece ser constitutivamente ativa, não requerendo a presença de subunidades citosólicas para sua ativação (HORDIJK, 2006; BEDARD e KRAUSE, 2007).

Um dos principais temas de investigação da literatura é a correlação entre a atividade e a distribuição de cada uma das isoformas da Nox em compartimentos celulares específicos. A isoforma Nox 4, por exemplo, foi descrita no retículo endoplasmático (AMBASTA et al., 2004), enquanto a isoforma Nox 1 parece estar presente em cavéolas (HILENSKI et al., 2004). Além disso, as diferentes isoformas da Nox parecem também participar de processos celulares distintos. Sabe-se que a Nox 4 está envolvida com a diferenciação e a apoptose de células vasculares, mas aparentemente não participa de mecanismos de proliferação destas células. Existem relatos na literatura segundo os quais a isoforma Nox 1 estaria preferencialmente envolvida com a proliferação celular em resposta a estímulos como a angiotensina II (MAHADEV et al., 2004; CLEMPUS e GRIENDLING, 2006). Especula-se também que a isoforma Nox 1 seja responsável pela geração de $\mathrm{O}_{2}$-- enquanto que a Nox 4 seria capaz de gerar preferencialmente $\mathrm{H}_{2} \mathrm{O}_{2}$ em células musculares vasculares lisas. $O$ tipo de espécie reativa gerada pode ser fundamental na determinação do papel biológico das Noxes (DIKALOV et al., 2008).

Alguns trabalhos sugerem que o aumento da atividade da NADPH oxidase deve contribuir para o quadro de estresse oxidativo observado em doenças neurodegenerativas. No mal de Alzheimer, por exemplo, os níveis de $\mathrm{p} 47^{\mathrm{PHOX}}$ e de p67 $7^{\text {PHOX }}$ estão significativamente elevados (SHIMOHAMA et al., 2000; SUZUKAWA et al., 2000), e pacientes com esclerose lateral amiotrófica apresentam um aumento na expressão de NADPH oxidase na medula. Este último dado sugere que o aumento da formação de EROs estaria possivelmente envolvido com a degeneração de neurônios motores característicos desta neuropatia (WU et al., 2006). 


\subsection{OBJETIVOS}

A proposta do presente estudo está relacionada com investigações realizadas nos últimos anos pelos Laboratórios de Neurobiologia celular (ICB-USP) e de Sinalização Redox (ICB-USP) com o objetivo de elucidar os mecanismos envolvidos na ativação da NADPH oxidase no sistema nervoso central. A melhor compreensão dos mecanismos celulares envolvidos na geração de EROs pela NADPH oxidase deve contribuir para o esclarecimento de eventos relevantes à fisiopatologia de lesões do sistema nervoso central. Assim, o objetivo principal desta parte do trabalho foi o de avaliar a produção e o impacto da geração EROs em áreas visuais primárias após enucleação ocular.

\section{Objetivos específicos:}

- Analisar a geração de espécies reativas de oxigênio no CS e no GLD desaferentados em diferentes tempos de sobrevida;

- Avaliar o efeito de enzimas decompositoras de espécies reativas, de um inibidor de flavoenzimas e do complexo I da cadeia transportadora de elétrons mitocondrial, bem como o efeito de um inibidor da nNOS sobre a geração de espécies reativas de oxigênio no CS e no GLD de ratos enucleados;

- Avaliar a geração de espécies reativas de oxigênio em animais desaferentados e tratados cronicamente com apocinina, um inibidor da NADPH oxidase;

- Investigar a expressão gênica de isoformas da NADPH oxidase no CS e no GLD após a enucleação ocular;

- Determinar a expressão e a distribuição protéica no CS e no GLD após enucleação ocular;

- Investigar a expressão e a distribuição protéica de neurofilamentos e de proteínas associadas a microtubulos em animais tratados crônica e agudamente com apocinina. 


\subsection{MATERIAL E MÉTODOS}

\subsubsection{Animais}

Foram utilizados ratos machos (Rattus novergicus) da linhagem Wistar, adultos, pesando entre 180 e $200 \mathrm{~g}$, provenientes do Biotério Central do Instituto de Ciências Biomédicas da Universidade de São Paulo. Os animais foram mantidos em temperatura controlada $\left(23^{\circ} \pm 2{ }^{\circ} \mathrm{C}\right)$, ciclo claro/escuro de 12 horas, $60 \%$ de umidade. Foram alimentados com ração padrão e água ad libitum. Todos os procedimentos realizados neste trabalho foram aprovados pela Comissão de Ética em Experimentação Animal (CEEA) do Instituto de Ciências Biomédicas da Universidade de São Paulo (protocolo n 017/2007).

\subsubsection{Procedimento cirúrgico}

Para a realização da enucleação ocular os animais foram anestesiados com quetamina ( $5 \mathrm{mg} / 100 \mathrm{~g}$ de peso) e xilazina ( $1 \mathrm{mg} / 100 \mathrm{~g}$ de peso), ambos por via intramuscular. O globo ocular direito foi completamente removido e, em seguida, foi aplicado um anestésico local (lidocaína). O espaço antes ocupado pelo globo ocular foi preenchido com material sintético de fibrina (Gelfoam, Upjohn, Michigan, USA), para acelerar o processo de cicatrização. As pálpebras foram então suturadas com fio cirúrgico e, imediatamente após o término do procedimento, os animais retornaram as suas gaiolas. As sobrevidas escolhidas dos animais foram 1 hora, 1, 7, 15 e 30 dias, de acordo com protocolo descrito por Chacur e colaboradores (CHACUR et al., 2006). Os animais do grupo controle não sofreram nenhum tipo de lesão. 


\subsubsection{Coloração com Giemsa}

Para visualização da citoarquitetura, alguns cortes de encéfalo foram submetidos à coloração com Giemsa. Após a montagem dos cortes em lâminas gelatinizadas, as mesmas foram colocadas placa de aquecimento a $37 \stackrel{\circ}{\circ}$ por 24 horas para melhor adesão dos cortes a lâmina.

As lâminas foram colocadas por 1 hora em uma solução de clorofórmio e álcool etílico 95\%. Em seguida, o tecido foi re-hidratado em uma bateria de álcoois $90 \%, 70 \%$ e água deionizada. As lâminas foram então, colocadas por sete minutos em solução de Giemsa previamente aquecida a $60{ }^{\circ} \mathrm{C}$ e, a seguir, foram lavadas em tampão fosfato-salina $0,1 \mathrm{M}$. A marcação foi verificada sob um microscópio óptico até que os cortes atingissem a coloração desejada. Após esses procedimentos, as

lâminas foram colocadas em uma solução de $1 \%$ de molibdato de amônio por 5 minutos para fixar a marcação. Em seguida, foram lavadas com água deionizada, desidratadas em álcoois e, em seguida imersas em um solvente clareador (Hemo-De, Fisher). As lâminas foram então cobertas com meio de montagem (Permount) e lamínulas.

\subsubsection{Drogas e reagentes utilizados}

A dihidroetidina (DHE) foi adquirida da Invitrogen (Carlsbad, CA, EUA), ressuspendida, aliquotada $(10 \mathrm{mM})$ e mantida em freezer $\left(-20{ }^{\circ} \mathrm{C}\right)$ protegida da luz até o momento da realização dos experimentos. A superóxido dismutase conjugada a polietilenoglicol (PEG-SOD), a catalase conjugada a polietilenoglicol (PEG-CAT), o 7nitroindazol (7-NI), o ácido dietilenotriaminopentaacético (DTPA) e a apocinina foram adquiridos da Sigma (St. Louis MO, USA). O diphenylene iodonium (DPI) foi adquirido da Calbiochem (San Diego, EUA). Todas as soluções foram preparadas com água purificada em sistema Milli-Q. 
Todas as drogas acima descritas são rotineiramente testadas e utilizadas em nosso laboratório e estão disponíveis comercialmente.

\subsubsection{Análise da fluorescência derivada dos produtos de oxidação da dihidroetidina em cortes histológicos}

Após a enucleação ocular os animais foram sacrificados por decapitação em diferentes tempos de sobrevida. Os encéfalos foram retirados e imersos em meio para congelamento (Leica Instruments) e imediatamente congelados em gelo seco. Foram feitos cortes coronais de $18 \mu \mathrm{m}$ em criostato e os cortes foram colocados em lâminas silanizadas. Os cortes foram então incubados com DHE $(2 \mu \mathrm{M})$ diluída em tampão fosfato (PB/DTPA $100 \mu \mathrm{M}$ ), em câmara úmida (5 minutos, a $37^{\circ} \mathrm{C}$ ), protegida de luz.

Um grupo de animais foi injetado com quetamina (50 mg/kg) e sacrificado 1 hora e 1 dia após a injeção. Os encéfalos coletados foram cortados em criostato e incubados com DHE.

Em experimentos adicionais, cortes histológicos foram incubados com PEGSOD (1000 U/mL), PEG-CAT (800 U/mL), 7-NI (1 mM) ou DPI $(10 \mu \mathrm{M})$ por 30 minutos com a finalidade de avaliarmos o tipo de espécie reativa gerada no tecido após enucleação ocular. Após este período, os cortes foram lavados duas vezes com PB/DTPA e então incubados com DHE em câmara úmida ( $2 \mu \mathrm{M}, 5$ minutos, a $37^{\circ} \mathrm{C}$ ). Todo o procedimento foi protegido de luz.

\subsubsection{Análise dos resultados}

A fluorescência dos cortes foi detectada em microscópio óptico Nikon com filtro para rodamina (excitação $480 \mathrm{~nm}$ e emissão $586 \mathrm{~nm}$ ), com objetiva de 20x, imediatamente após a reação com DHE. As imagens digitais do CS e do GLD foram obtidas por meio de uma câmera de vídeo acoplada ao microscópio e as figuras 
correspondentes foram montadas com o auxílio do programa Adobe Photoshop. As lâminas obtidas de animais enucleados foram sempre comparadas com as lâminas obtidas de animais controles de acordo com parâmetros previamente estabelecidos. Para a quantificação da fluorescência foi avaliada a densidade integrada das imagens digitais utilizado-se o programa ImageJ 4.37 (Wayne Rasband, National Institutes of Health, USA).

\subsubsection{Quantificação de mRNA por real-time PCR (RT - PCR)}

A expressão gênica das isoformas da NADPH oxidase (Nox 1, Nox 2 e Nox 4) foi avaliada pela reação em cadeia da polimerase em tempo real (Real-time PCR) nas amostras de CS e do CGL tálamo de ratos. Para tanto, o tecido foi removido, imediatamente congelado em nitrogênio líquido e mantido a $-70{ }^{\circ} \mathrm{C}$ até o dia do processamento.

\subsubsection{Extração do ácido ribonucléico total (tRNA)}

O RNA total (tRNA) foi obtido pela homogeneização das amostras de tecidos em Trizol [isotiocinato de guanidina (TCG) em solução de fenol - Invitrogen Brasil LTDA (1 mL/50-100 mg de amostra)]. Após a homogeneização as amostras foram incubadas por 5 min à temperatura ambiente e, então, centrifugadas a $12000 \mathrm{~g} \mathrm{(15}$ min, $4{ }^{\circ} \mathrm{C}$ - Eppendorf Centrífuge modelo $5417 \mathrm{R}$ - Eppendorf, Califórnia, EUA). Posteriormente $0,8 \mathrm{~mL}$ da fase superior foi transferida para um novo tubo (Eppendorf) no qual foram adicionados $0,2 \mathrm{~mL}$ de clorofórmio. Após 15 segundos de agitação vigorosa por inversão, os tubos foram deixados em repouso por 2-3 minutos à 
temperatura ambiente, e posteriormente centrifugados a $12000 \mathrm{~g}\left(15 \mathrm{~min}\right.$ a $\left.4{ }^{\circ} \mathrm{C}\right)$. A fase aquosa sobrenadante $(\approx 600 \mu \mathrm{L})$ foi, então, separada para novo tubo.

\subsubsection{Precipitação e lavagem do tRNA}

O tRNA foi precipitado pela adição de 1 volume de isopropanol para cada volume de sobrenadante. Após 15 segundos de agitação por inversão os tubos foram incubados por 10 minutos a temperatura ambiente e, então, centrifugados a $12000 \mathrm{~g}$. $\left(10 \min\right.$ a $\left.4^{\circ} \mathrm{C}\right)$.

\subsubsection{Lavagem do tRNA}

Para a lavagem do tRNA, os sobrenadantes foram descartados (vertidos) e o RNA precipitado (pellet) foi lavado com etanol 100\% (1 $\mathrm{mL} / \mathrm{mL}$ de Trizol) e posteriormente centrifugados a $7600 \mathrm{~g}$, (5 min, $\left.4{ }^{\circ} \mathrm{C}\right)$. Após centrifugação, os sobrenadantes foram descartados (vertidos) e o pellet foi lavado com $1 \mathrm{~mL}$ de etanol 75\% [diluído em água tratada com dietil-pirocarbonato (DEPC) 0,01\% e inativada em autoclave]. Posteriormente, foi realizada nova centrifugação a $7600 \mathrm{~g}$ (5 min, 4 $\left.{ }^{\circ} \mathrm{C}\right)$, sendo os sobrenadantes novamente desprezados, os tubos vertidos e com o auxílio de ponteiras eliminaram-se por capilaridade os resíduos de etanol. Os tubos foram, ainda, deixados por 10 min à temperatura ambiente para total secagem do pellet, dando-se início à digestão das amostras com DNAse I. 


\subsubsection{Digestão do DNA}

Para a digestão do DNA, os pellets secos foram ressuspendidos em $43,5 \mu \mathrm{L}$ de água DEPC inativa $0,01 \%$. Posteriormente foram adicionados $6,5 \mu \mathrm{L}$ do mix para digestão do DNA ( $5 \mu \mathrm{L}$ do Tampão 10X, 0,5 $\mu \mathrm{L}$ de Inibidor de RNAse e $1 \mu \mathrm{L}$ de DNAse I - Invitrogen Brasil LTDA) sendo o volume final de $50 \mu \mathrm{L}$. Em seguida, as amostras foram incubadas a $37^{\circ} \mathrm{C}$ por $15 \mathrm{~min}$. Posteriormente foi adicionado $1 \mu \mathrm{L}$ de solução de interrupção (EDTA $25 \mathrm{mM}$ ) e em seguida o material foi submetido à reextração do tRNA.

\subsubsection{Re-extração do tRNA}

Para a re-extração do tRNA foram adicionados $50 \mu \mathrm{L}$ de água DEPC inativa $0,01 \%$ às amostras previamente submetidas ao ensaio de digestão do DNA. Posteriormente, foram adicionados $200 \mu \mathrm{L}$ da mistura fenol saturado em tampão (Invitrogen Brasil LTDA)/clorofórmio 1:1 e, após agitação por inversão, foram incubadas por 2-3 minutos a temperatura ambiente; por fim, as amostras foram centrifugadas a $12000 \mathrm{~g}\left(15 \mathrm{~min}\right.$ a $4{ }^{\circ} \mathrm{C}$ ). A seguir, a fase aquosa (sobrenadante) foi transferida para um novo tubo e a esta, foram adicionados $200 \mu \mathrm{L}$ de isopropanol 100\% (para nova precipitação do RNA). Após agitação por 15 segundos e incubação por 10 min a temperatura ambiente, as amostras foram centrifugadas a $12000 \mathrm{~g}$ (10 min a $4{ }^{\circ} \mathrm{C}$ ), sendo o sobrenadante, então, descartado (vertido). Posteriormente foram adicionados $500 \mu \mathrm{L}$ de etanol $100 \%$ (para lavagem do pellet), as amostras centrifugadas a $7600 \mathrm{~g},\left(5 \mathrm{~min}, 4{ }^{\circ} \mathrm{C}\right)$ e o sobrenadante foi novamente descartado (vertido). Adicionou-se então, $500 \mu \mathrm{L}$ de etanol $75 \%$ (para lavagem do pellet) precedendo nova centrifugação a $7600 \mathrm{~g},\left(5 \mathrm{~min}, 4^{\circ} \mathrm{C}\right)$, bem como nova remoção do sobrenadante, adicionando-se por fim $500 \mu \mathrm{L}$ de etanol $75 \%$ e congelando-se as amostras a $-20{ }^{\circ} \mathrm{C}$. 


\subsubsection{Quantificação do tRNA}

Para a quantificação do tRNA, as amostras contendo etanol $75 \%$ foram centrifugadas e o pellet de tRNA foi novamente seco. Posteriormente, ressuspendeuse o pellet de tRNA em volume adequado $(\approx 20-30 \mu \mathrm{L})$ de água DEPC inativa $0,01 \%$. As absorbâncias foram então medidas a $260 \mathrm{~nm}$ em espectrofotômetro (Eppendorf BioPhotometer - Eppendorf, CA, EUA), sendo as concentrações de tRNA calculadas considerando a relação $1 \mathrm{AU}=40 \mu \mathrm{g} / \mathrm{mL}$, conforme a fórmula (1):

[RNA $\mu \mathrm{g} / \mathrm{ml}]=$ Abs $\times$ Fator de diluição $\times 40$ (1)

Foram consideradas adequadas as razões $260^{\mathrm{RNA} / 280^{\text {Prot }}}$ entre 1,8 e 2,0.

\subsubsection{Integridade do tRNA}

A integridade do tRNA isolado foi verificada por meio da eletroforese em gel de agarose 1\% diluído em tampão TRIS acetato EDTA, contendo $2 \mu \mathrm{L} / 100 \mathrm{~mL}$ de brometo de etídio $(0,5 \mu \mathrm{g} / \mathrm{mL})$, Invitrogen Brasil LTDA, aplicando-se em cada poço (lane), $5 \mu \mathrm{L}$ de uma solução contendo: $1 \mu \mathrm{g}$ de amostra de RNA; $3,5 \mu \mathrm{L}$ de $\mathrm{H}_{2} \mathrm{O}$ DEPC $0,01 \%$ e $1 \mu \mathrm{L}$ de tampão de amostra (contendo glicerol 50\%, azul de bromofenol $0,25 \%$ e $1 \mathrm{mM}$ de EDTA $\mathrm{pH}$ 8,0), fixando-se uma voltagem de $70 \mathrm{~V}$ por aproximadamente $1 \mathrm{~h}$ (até correr 2/3 do gel).

Posteriormente, os géis foram revelados sob luz ultravioleta (UV) e as imagens foram capturadas com um detector de imagem Chime-Imager 5500-Alpha Innotech Corporation. O tempo de exposição foi ajustado pelo "autoexpose" do aparelho (exposição normal para saturação da imagem em torno de alguns 
milisegundos). Por fim, foram visualizadas as bandas $28 \mathrm{~S}$ e $18 \mathrm{~S}$, indicadoras da integridade do RNA.

2.3.6.8 Reação de Transcrição do Ácido Desoxirribonucléico complementar (cDNA)

Cuidadosamente, $2 \mu \mathrm{g}$ de tRNA foram adicionados a $10 \mu \mathrm{L}$ de $\mathrm{H}_{2} \mathrm{O}$ DEPC inativa $0,01 \%$. Esta solução foi, então, aquecida a $65{ }^{\circ} \mathrm{C}$ por $5 \mathrm{~min}$, seguida por choque térmico em gelo. A esta solução foram adicionados $10 \mu \mathrm{L}$ de um mix contendo $1 \mu \mathrm{L}$ de oligo dT (0,5 $\mu \mathrm{g} / \mu \mathrm{L}$ - Invitrogen Brasil LTDA); $1 \mu \mathrm{L}$ da mistura de trifosfato de desoxinucleotídeos (dNTPs), a saber - $10 \mathrm{mM}$ de dATP, $10 \mathrm{mM}$ de dTTP, $10 \mathrm{mM}$ de dCTP e $10 \mathrm{mM}$ de dGTP - Invitrogen Brasil LTDA; $4 \mu \mathrm{L}$ de tampão de reação (5X first strand buffer), $2 \mu \mathrm{L}$ de DTT $(0,1 \mathrm{M}), 1 \mu \mathrm{L}$ de RNAse OUT (40 U/ $\mu \mathrm{L}$ ) e, por último, $1 \mu \mathrm{L}$ da enzima Superscript II (200 U/ $\mu \mathrm{L})$. A fim de assegurar a ausência de DNA na amostra foram utilizados controles negativos da reação de RT, consistindo de "pool" de RNAs contendo todos os reagentes citados anteriormente com omissão da Superscript II.

A mistura foi posteriormente homogenizada e incubada a $42{ }^{\circ} \mathrm{C}$ durante 50 min em banho-maria, sendo posteriormente incubada a $70^{\circ} \mathrm{C}$ durante $15 \mathrm{~min}$ em banho-maria para inativação da enzima. As amostras foram, então, mantidas a -20 ${ }^{\circ} \mathrm{C}$ até serem submetidas à reação em cadeia de polimerase (PCR).

\subsubsection{Reação em Cadeia de Polimerase em tempo real (Real time PCR)}

A reação em cadeia de polimerase em tempo real (RT-PCR) foi realizada em um volume final de $12,5 \mu \mathrm{L}$ contendo $1 \mu \mathrm{L}$ de cDNA, $0,5 \mu \mathrm{L}$ do oligonucleotídeo sense $\left(10^{-5} \mathrm{M}\right), 0,5 \mu \mathrm{L}$ do oligonucleotídeo antisense $\left(10^{-5} \mathrm{M}\right) ; 4,25 \mu \mathrm{L}$ de $\mathrm{H}_{2} \mathrm{O}$ DEPC 
autoclavada e por fim $6,25 \mu \mathrm{L}$ de Platinum ${ }^{\circledR}$ SYBR $^{\circledR}$ green qPCR SuperMix-UDG (Invitrogen), o qual contém Platinum ${ }^{\circledR}$ Taq DNA polimerase, corante SYBR ${ }^{\circledR}$ green I, Tris- $\mathrm{HCl}, \mathrm{KCl}, 6 \mathrm{mM} \mathrm{MgCl}, 400 \mu \mathrm{M}$ dGTP, $400 \mu \mathrm{M}$ dATP, $400 \mu \mathrm{M}$ dCTP, $800 \mu \mathrm{M}$ dUTP, uracil DNA glicosilase (UDG) e agentes estabilizadores.

A integridade das amostras de mRNA foi avaliada por eletroforese em gel de agarose $1 \%$.

As seqüências dos oligonucleotídeos para as isoformas da NADPH oxidase (Nox 1, Nox 2 e Nox 4) foram extraídas do GeneBank (http://www.ncbi.n/m.nih.gov) e desenhadas com o auxílio do software Primer3 (http://frodo.wimit.edu). As seqüências geradas no programa Primer3 foram analisadas no Blast quanto à especificidade e tamanho do fragmento. Todos os oligonucleotídeos utilizados também foram analisados no programa oligo analyzer (http://www.idtdna.com/analyzer/Applications/OligoAnalyzer) quanto ao TM e formação de estuturas que pudessem interferir no ensaio de PCR (loops, hairpins, primerdimers, etc). As seqüências dos oligonucleotídeos utilizados para amplificação do cDNA, bem como o número de acesso ao GeneBank, foram apresentados na Tabela 1. 
Tabela 1 - Sequências de oligonucleotídeos e número de acesso ao GeneBank.

\begin{tabular}{|c|c|c|c|}
\hline Gene & $\begin{array}{c}\text { Sequências senso (S) e } \\
\text { anti-senso (AS) }\end{array}$ & $\begin{array}{l}\text { Número de } \\
\text { acesso ao } \\
\text { GeneBank }\end{array}$ & $\begin{array}{l}\text { Tamanho do } \\
\text { fragmento } \\
\text { (pares de base) }\end{array}$ \\
\hline GAPDH & $\begin{array}{l}\text { (S) GATGCTGGTGCTGAGTATGTCG } \\
\text { (AS) GTGGTGCAGGATGCATTGCTGA }\end{array}$ & NM_017008 & 175 \\
\hline Nox 1 & $\begin{array}{l}\text { (S) TTCCCTGGAACAAGAGATGG } \\
\text { (AS) GACGTCAGTGGCTCTGTCAA }\end{array}$ & AF152963 & 127 \\
\hline Nox 2 & $\begin{array}{l}\text { (S) TCATCACATCCTCCACCAAA } \\
\text { (AS) TCCACGTACAATTCGCTCAG }\end{array}$ & AF298656 & 125 \\
\hline Nox 4 & $\begin{array}{l}\text { (S) CTGGAAGAACCCAAGTTCCA } \\
\text { (AS) CGGATGCATCGGTAAAGTCT }\end{array}$ & AY027527 & 101 \\
\hline
\end{tabular}




\subsubsection{Imuno-histoquímica}

Sete dias após a lesão os animais foram anestesiados e submetidos à perfusão transcardíaca, com solução salina tamponada seguida de solução fixadora constituída de $4 \%$ de paraformaldeído (PFA) dissolvido em tampão fosfato salina $0,1 \mathrm{M}(\mathrm{PB} \mathrm{pH} 7,4)$. Após a perfusão, os encéfalos foram coletados e mantidos em $4 \%$ de PFA durante 4 horas. Após este período, o encéfalo foi transferido para uma solução de PB contendo $30 \%$ de sacarose, para crioproteção, por um período de 48 horas. Em seguida, o encéfalo foi cortado em um micrótomo deslizante para congelamento. Os cortes histológicos, com $30 \mu \mathrm{m}$ de espessura, foram colocados em placa de cultivo de 6 compartimentos, mantidos sob agitação constante e submetidos às seguintes etapas: a) inicialmente os cortes foram submetidos a três lavagens de 10 minutos cada, em PB; b) em seguida incubados "overnight" à temperatura ambiente, em solução incubadora, que continha PB-T (0,3\% de Triton X-100), 5\% de soro normal de cabra e anticorpo monoclonal primário específico contra neurofilamentos (NFs) que reconhece neurofilamentos de 68, 160 e 200 kDas, (Zymed, CA, EUA), contra proteínas associadas ao microtúbulo 2 (MAP-2) (Millipore, MA, EUA), contra GFAP (proteína fiblilar acídica glial) (Sigma, MI, EUA), que reconhece astrócitos, ou contra OX42 (BD Biosciences, CA, EUA), que reconhece microglia, todos diluídos a 1:1000; c) após período de incubação, os cortes foram submetidos a três lavagens de 10 minutos cada com PB; d) os cortes foram incubados durante duas horas à temperatura ambiente, com anticorpo secundário biotinilado, diluído a 1:200 em PB contendo 0,3\% de Triton X-100; e) após este período, submetidos a três lavagens de 10 minutos em PB; f) incubados novamente com um complexo avidina-biotina-peroxidase (ABC-Elite, Vector, CA, USA) preparada com $10 \mu \mathrm{L}$ da solução $A$ e $10 \mu \mathrm{L}$ da solução $B$ por $\mathrm{mL}$ de PB contendo $0,3 \%$ de Triton $\mathrm{X}-100$ e $\mathrm{NaCl}(0,3 \mathrm{M}-0,5 \mathrm{M})$ durante 1 hora e meia à temperatura ambiente; g) submetidos a três lavagens com PB durante 10 minutos cada.

A marcação com peroxidase foi realizada utilizando o cromógeno 3,3'diaminobenzidina (DAB) dissolvido em PB durante 3 minutos, e em seguida foi 
adicionada uma solução de $0,3 \%$ de peróxido de hidrogênio em água destilada. Após o desenvolvimento da cor, os cortes foram lavados três vezes com PB de 10 minutos cada. Os cortes foram então colocados sobre lâminas de vidro gelatinizadas e deixados por aproximadamente 24 horas em uma placa de aquecimento a $37 \stackrel{\circ}{\mathrm{C}}$ para uma melhor adesão dos cortes nas lâminas. Em seguida, as lâminas foram deixadas por 5 minutos em água destilada e mergulhadas em uma solução de 0,05\% de tetróxido de ósmio por aproximadamente 15 segundos para intensificação da marcação. Logo após, as lâminas foram submetidas a 3 lavagens de 10 minutos cada em PB e submetidas a uma bateria de desidratação, que consiste em uma série crescente de álcoois e por um solvente clareador (Hemo-De, Fisher, PA, EUA) com duração de 5 minutos para cada estágio. As lâminas foram então cobertas com lamínulas usando Permount (Fisher, PA, EUA) como meio de montagem.

\subsubsection{Análise dos resultados}

As imagens digitais do CS e do GLD foram obtidas por meio de uma câmera de vídeo acoplada ao microscópio óptico Nikon. A média da densidade óptica de imagens digitais do CS e do GLD foi comparada com a média da densidade óptica de regiões adjacentes às estruturas analizadas no respectivo corte histológico utilizandose o programa ImageJ 4.37 (Wayne Rasband, National Institutes of Health, USA). Desta maneira, obteve-se um índice que reflete a razão entre regiões marcadas e não marcadas. Os índices obtidos foram comparados estatisticamente entre animais controles e experimentais. 


\subsubsection{Immunoblotting}

Sete dias após a lesão os animais foram sacrificados por decapitação e o CS foi rapidamente coletado e homogeneizado com o auxílio de um sonicador em tampão de extração (100mM de Tris pH7,4, 100mM de pirofosfato de sódio, 100mM de fluoreto de sódio, $10 \mathrm{mM}$ de EDTA, $10 \mathrm{mM}$ de ortovanadato de sódio, $2 \mathrm{mM}$ de PMSF e $0,01 \mathrm{mg} / \mathrm{ml}$ de aprotinina). Posteriormente, as amostras foram incubadas com $1 \%$ de Triton-X 100 por 30 minutos a $4{ }^{\circ} \mathrm{C}$, e em seguida centrifugadas a 12.000 rpm a $4{ }^{\circ} \mathrm{C}$ por 20 minutos para a remoção do material insolúvel. Parte do sobrenadante foi utilizada para determinação do conteúdo protéico por espectrofotometria, utilizando-se o reagente para ensaio de proteína (BioRad Protein Assay-Dye Reagent Concentratei; Melville, NY), e foi utilizada curva padrão de albumina como referência. O restante do sobrenadante foi diluído em tampão Laemmli (azul de bromofenol 0.1\%, fosfato de sódio $1 \mathrm{M} \mathrm{pH} \mathrm{7,0,} \mathrm{glicerol} 50 \%$ e SDS $10 \%$ ) contendo $200 \mathrm{mM}$ de DTT (ditiotreitol), em proporção de 5:1 e fervidas por 5 minutos. As amostras assim obtidas foram congeladas e mantidas a $-70{ }^{\circ} \mathrm{C}$ até sua utilização. De 50 a 100mg de proteína total foram submetidos a eletroforese em gel bifásico (gel de empilhamento e gel de resolução 8\%) em aparelho para minigel de poliacrilamida (Mini-Protean, Bio-Rad; Melville, NY), juntamente com marcador de peso molecular pré-corado disponível comercialmente (Bio-Rad; Melville, NY). A transferência das proteínas foi feita eletricamente para uma membrana de nitrocelulose (Amersham Biosciences; Piscataway, NJ), utilizando aparato para transferência semi-seca (Bio-Rad; Melville, NY) e realizada durante 2 horas a 120V em gelo, banhada com tampão de transferência.

Após a transferência, as membranas foram incubadas com solução bloqueadora constituída de $5 \%$ de leite desnatado diluído em solução basal (10 mM de Tris, $150 \mathrm{mM}$ de $\mathrm{NaCl}$ e $0,02 \%$ de Tween 20) a $4{ }^{\circ} \mathrm{C}$ overnight ou à temperatura ambiente, durante 2 horas. Em seguida, as membranas foram lavadas 4 vezes durante 5 minutos com solução basal sob agitação. Posteriormente foram incubadas com o anticorpo específico contra NFs, MAP-2 (1:1000) ou $\beta$-actina (Sigma, MI, EUA) 
na concentração 1:10.000 overnight, a $4^{\circ} \mathrm{C}$. Após incubação, as membranas foram lavadas 3 vezes durante 10 minutos com solução basal sob agitação e incubadas, à temperatura ambiente, com anticorpos secundários anti-lgG ligados à peroxidase extraída de raiz forte (HRP), por 1 hora. A seguir, as membranas foram lavadas com solução basal sob agitação e reveladas. Para revelação utilizou-se o kit de quimioluminescência ECL (Amersham Biosciences; Piscataway, NJ). As soluções 1 e 2 do kit foram adicionadas na proporção 1:1, recobrindo as membranas e após 1 minuto de reação as membranas foram secas em papel de filtro e expostas a filme de raio-X.

\subsubsection{Análise dos resultados}

A intensidade das bandas reativas formadas foi quantificada por densitometria óptica (Scion Image - Release Beta 3b, NIH, USA) e corrigida pela densidade observada para a $\beta$-actina, considerando-se as amostras dos animais controles como o padrão para a normalização dos resultados.

\subsubsection{Tratamento com apocinina}

Animais enucleados foram cronicamente tratados com apocinina (12mg/kg/dia na água de beber) por 7 ou 30 dias após a lesão. Em experimentos adicionais, a apocinina foi agudamente administrada $(200 \mathrm{mg} / \mathrm{kg}$ i.p. 30 minutos antes da lesão) em animais controles e desaferentados (7 dias). Os encéfalos coletados foram utilizados para análise da fluorescência derivada dos produtos de oxidação da DHE e para os experimentos de immunoblotting e imuno-histoquímica. 


\subsubsection{Preparo da apocinina}

A apocinina foi diariamente pré-diluída em etanol absoluto. Esta solução foi adicionada aos bebedouros de água dos animais em tratamento, obtendo-se assim a concentração final desejada (CERAVOLO et al., 2007). Além disso, para os tratamentos agudos, a apocinina foi re-diluída em solução salina e esta solução foi injetada intraperitonealmente.

\subsubsection{Análise estatística}

Os dados estão representados como média \pm e.p.m. A análise estatística dos dados foi gerada utilizando o programa GraphPad Prism, versão 3.02 (GraphPad Software Inc., San Diego, CA, USA). A comparação estatística entre os grupos foi realizada usando a análise de variância (ANOVA) de duas vias. O índice de significância considerado foi de $p \leq 0,05$. 


\subsection{RESULTADOS}

\subsubsection{Coloração com Giemsa}

Pela coloração com Giemsa de cortes coronais do encéfalo de rato (Figuras 2.2A e B) e através da comparação dos resultados com os esquemas da Figura 2.1, foi possível identificar a disposição e divisão anatômica das estruturas a serem avaliadas.

\subsubsection{Determinação dos grupos controles}

Inicialmente, todos os esforços foram realizados na tentativa de comparar os efeitos da enucleação ocular entre as estruturas contralaterais e ipsolaterais à lesão do mesmo animal; porém, fica claro mediante aos resultados aqui expostos, que a lesão pode afetar de maneira assimétrica tanto estruturas contralaterais quanto ipsolaterais. Tais observações foram ilustradas aqui apenas por alterações na distribuição proteica de astrócitos (GFAP) e de microglia (OX42) após a lesão (Figuras 2.3 e 2.4). Estes resultados inviabilizaram a utilização do lado ipsolateral à lesão como controle. A partir de então, foram considerados animais do grupo controle aqueles que não sofreram nenhum tipo de lesão, uma vez que não é possível realizar uma falsa operação nestes animais (sham) que mimetize as condições as quais foram submetidos os animais enucleados. 


\subsubsection{Análise da fluorescência derivada dos produtos de oxidação da dihidroetidina em cortes histológicos}

Foram avaliados os efeitos da enucleação ocular sobre a geração de EROs nas estruturas retinorrecipientes CS (Figura 2.5A e B) e GLD (Figuras 2.6A e B). Para tanto, utilizou-se a técnica de fluorescência dos produtos de oxidação da DHE. A fluorescência total derivada da oxidação da DHE permitiu a análise da produção total de EROs em cortes histológicos, sem distinguir os diferentes produtos fluorescentes derivados de sua oxidação.

Observou-se um forte aumento da fluorescência total derivada da oxidação da DHE e, portanto, da geração de EROs nas camadas superficiais do CS em comparação com o grupo controle, em todos os tempos de sobrevida avaliados (Figura 2.5A). Resultado semelhante também foi observado no GLD do tálamo, contudo, apenas sete $(360 \%)$ e quinze $(421 \%)$ dias após a lesão (Figura $2.6 \mathrm{~A})$.

A análise comparativa do CS e do GLD dos hemisférios cerebrais direito e esquerdo dos animais dos grupos controles não revelou nenhuma diferença quanto à geração de EROs. Ou seja, não existe diferença basal quanto a geração de EROs entre os dois hemisférios cerebrais em cada uma das estruturas avaliadas (Figuras 2.7 e 2.8 ).

Com a finalidade de avaliarmos se a dose de quetamina utilizada como anestésico poderia aumentar a geração EROs em estruturas retinorrecipientes, um grupo de animais intactos foi injetado com quetamina e sacrificado nos períodos de uma hora e um dia após a injeção. Em nossos experimentos, a administração intramuscular de quetamina não foi capaz de aumentar a geração de EROs detectada por fluorescência dos produtos de oxidação da DHE (dados não mostrados).

A pré-incubação dos cortes histológicos com PEG-SOD (1000 U/mL) foi capaz de inibir o sinal da fluorescência tanto no CS (61\%) quanto no GLD (78\%). Em contrapartida, a PEG-CAT $(800 \mathrm{U} / \mathrm{mL})$ e o $7-\mathrm{NI}$ inibiram significativamente o sinal da fluorescência apenas no GLD (PEG-CAT 54\% e 7-NI 63\%). A pré-incubação dos 
cortes com $10 \mu \mathrm{M}$ de DPI aboliu completamente a geração de EROs nas duas estruturas avaliadas (Figuras 2.9A e B). Além disso, o DPI também foi capaz de inibir a geração de EROs em cortes histológicos de animais do grupo controle.

\subsubsection{Tratamento com apocinina}

Um grupo de animais desaferentados foi tratado com apocinina por 7 dias consecutivos (12mg/kg/dia na água de beber). Os animais do grupo controle receberam o mesmo tratamento, porém não sofreram nenhum tipo de lesão. $O$ tratamento com apocinina reverteu o aumento da geração observado tanto no CS (51\%) quanto no GLD (80\%) para os níveis basais de geração. O tratamento não alterou a geração nos animais dos grupos controles (Figura 2.10).

\subsubsection{Quantificação de mRNA por real-time PCR}

Foram demonstrados os efeitos da enucleação ocular sobre a expressão gênica das isoformas da NADPH oxidase (Nox 1, Nox 2 e Nox 4) no CS e no tálamo. A integridade das amostras de mRNA de CS (Figura 2.11) e de tálamo (Figura 2.13) foi confirmada por eletroforese em gel de agarose $1 \%$.

No CS contrateral à lesão, observou-se o aumento da expressão gênica das isoformas Nox $1\left(1^{\circ}\right.$ dia $124 \%, 7^{\circ}$ dia $84 \%, 15^{\circ}$ dia $92 \%$ e $30^{\circ}$ dia $141 \%$ ) e Nox 2 ( $1^{\circ}$ dia $92 \%, 7^{\circ}$ dia $74 \%, 15^{\circ}$ dia $113 \%$ e $30^{\circ}$ dia $96 \%$ ) em todos os períodos avaliados em comparação com o grupo controle (Figura 2.12 A e B). Além disso, também foi observado aumento significativo da expressão gênica de Nox 4 nos períodos de 1 (102\%), 7 (65\%) e 30 (104\%) dias pós-lesão (Figura 2.12 C). 
No tálamo, não foram observadas alterações na expressão de mRNA da isoforma Nox 1 (Figura $2.14 \mathrm{~A}$ ). Em contrapartida, observou-se aumento da expressão gênica da isoforma Nox 2 (Figura 2.14 B) nos períodos de 15 (118\%) e 30 (143\%) dias pós-lesão. Quanto à isoforma Nox 4, os resultados indicam que houve uma redução na expressão gênica de aproximadamente $62 \%$ entre um e sete dias pós-lesão (Figura 2.14 C).

\subsubsection{Imuno-histoquímica}

Foi observado aumento da imunorreatividade para NFs e MAP-2 no CS e no GLD 7 e 30 dias após enucleação ocular (Figuras 2.15- 2.20). O tratamento crônico com apocinina (12mg/kg/dia na água de beber por 7 e 30 dias) foi capaz de reduzir a imunorreatividade para NFs e MAP-2 em ambas as estruturas retinorrecipientes analisadas. De maneira semelhante, o tratamento agudo com apocinina $(200 \mathrm{mg} / \mathrm{kg}$ i.p. 30 minutos antes da lesão) também foi capaz de atenuar a expressão de NFs e MAP-2 no CS e no GLD de animais desaferentados. Em animais dos grupos controles, a imunorreatividade para NFs e MAP-2 não foi alterada pelo tratamento com apocinina.

\subsubsection{Immunoblotting}

Considerando que a técnica de imuno-histoquímica é apenas semiquantitativa, optamos por também avaliar a expressão proteica de NFs e MAP-2 após a enucleação ocular pelo método de immunoblotting. Como NFs são compostos por três tipos de polipeptideos, um com baixo (NF68), um com médio (NF160) e outro com alto (NF200) peso molecular, por esta técnica foi possível discriminar o aumento 
da expressão protéica dos três tipos de proteínas. Em consonância com os resultados obtidos pelo método de imuno-histoquímica, os dados de quantificação protéica revelaram que há um aumento significativo na expressão de NF68 $(527 \%)$ e NF160 (149\%) CS 7 dias após a enucleação ocular (Figura 2.21 A e B). Este aumento foi atenuado por ambos os tratamentos, agudo (NF68, 78\%; NF160, 73\%) e crônico (NF68, 36\%; NF160, 64\%), com apocinina (Figura 2.21 A e B). Não foram encontradas alterações significativas no padrão de expressão de NF200 (Figura 2.21 C). A análise do conteúdo proteico de MAP-2 revelou alteração significativa no CS, a qual também foi reduzida pelo tratamento crônico (37\%) e agudo (57\%) com apocinina (Figura 2.22). 
A

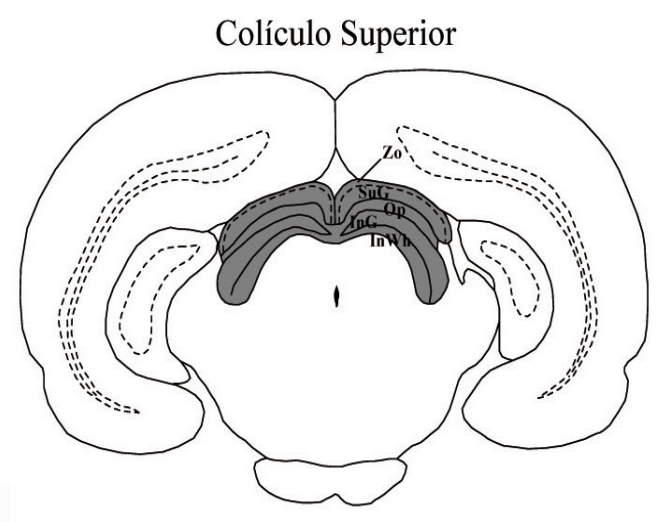

B

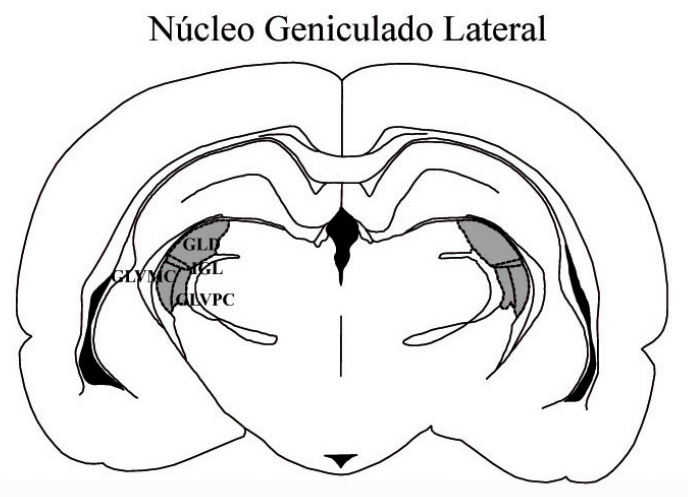

Figura 2.1 - Esquema representativo do colículo superior $(A)$ e do núcleo geniculado lateral (B). Em A ZO: camada zonal; SuG: camada cinzenta superficial; Op: camada óptica; InG: camada cinzenta intermediária; InWh: camada branca intermediária. Em B GLD: núcleo geniculado lateral dorsal; GLVPC: núcleo geniculado lateral ventral, porção parvocelular; GLVMC: núcleo geniculado lateral ventral, porção magnocelular.

Fonte: Adaptado de Paxinos e Watson, 2005.

A

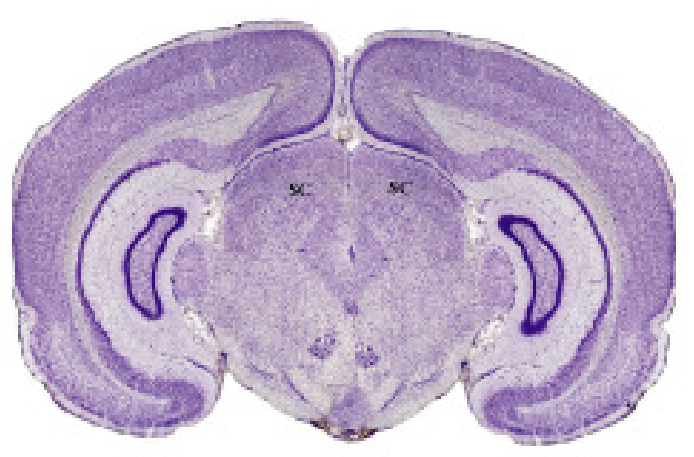

B

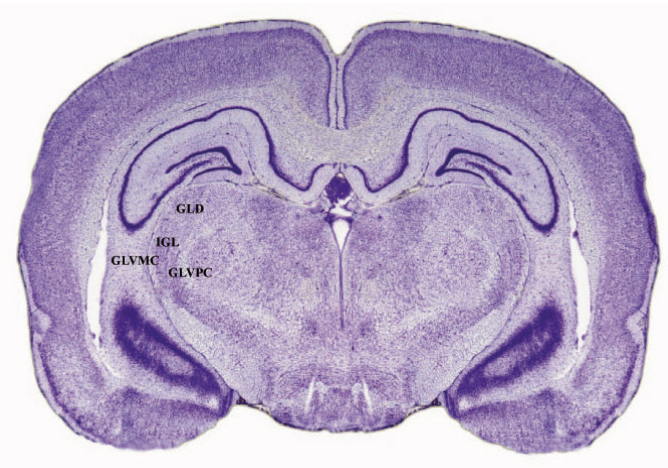

Figura 2.2 - Imagens de cortes coronais de encéfalo de rato corados pelo método de Giemsa ilustrando as estruturas descritas na Figura 1. 

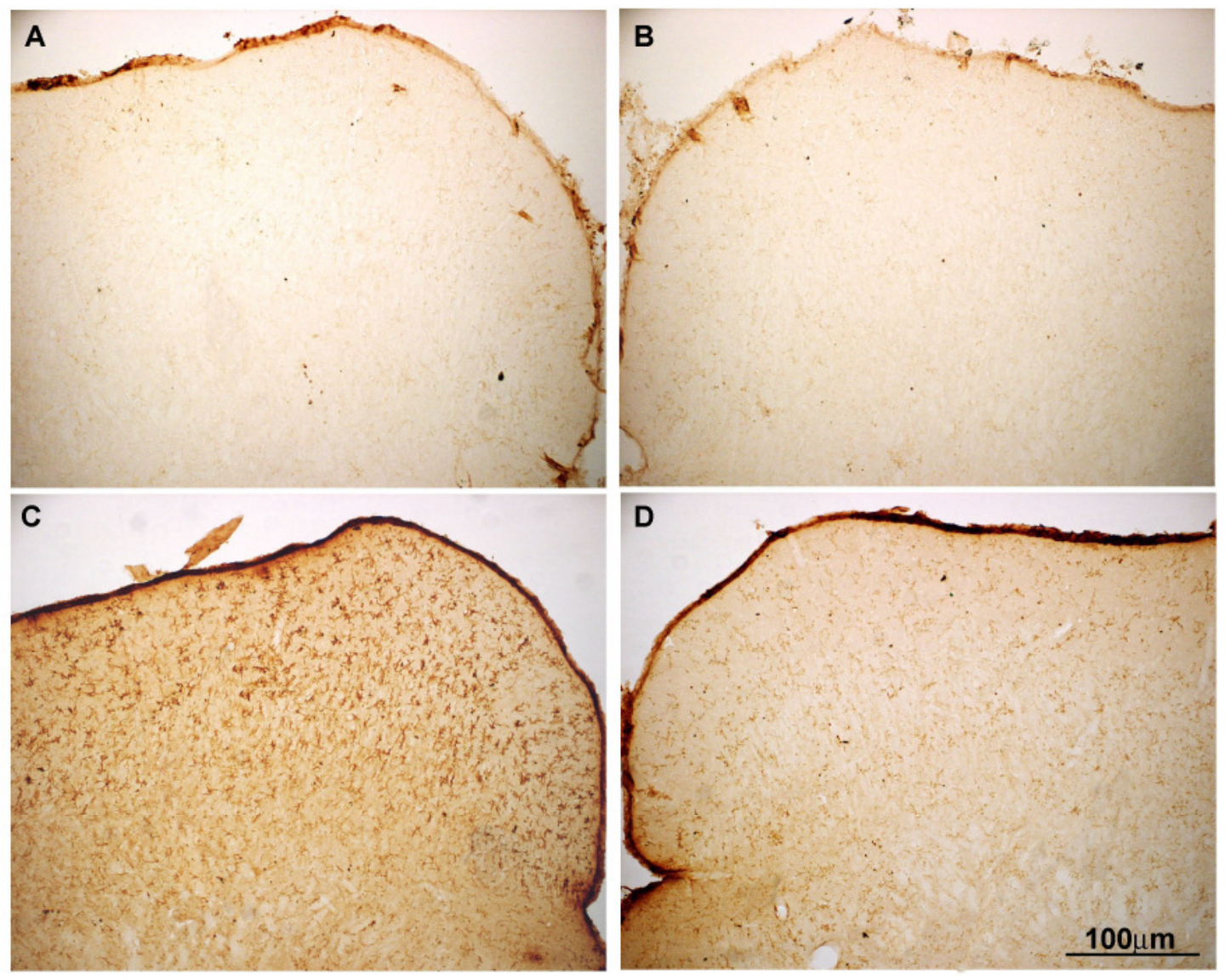

Figura 2.3 - Imagens coronais do encéfalo de ratos ilustrando o padrão de marcação para OX42 no CS, 7 dias após a enucleação ocular. Em (A), CS esquerdo e em (B), CS direito de animal do grupo controle, sem diferença da imunorreatividade. Em (C), CS contralateral e em (D) CS ipsolateral à lesão representando o aumento da imunorreatividade para microglia em comparação com animal intacto. 

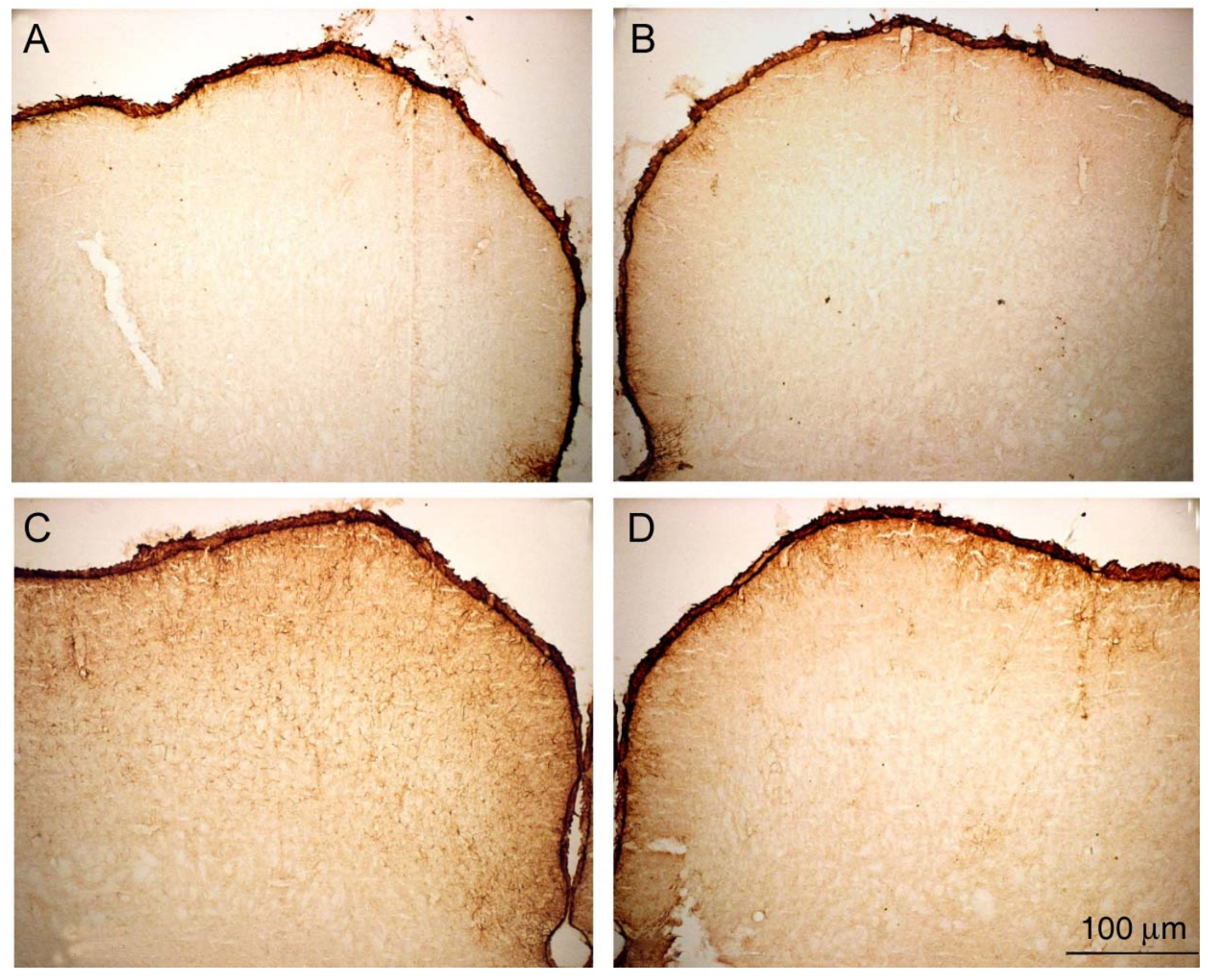

Figura 2.4 - Imagens coronais do encéfalo de ratos ilustrando o padrão de marcação para GFAP no CS, 7 dias após enucleação ocular. Em (A), CS esquerdo e em (B), CS direito de animal do grupo controle, sem diferença da imunorreatividade. Em (C), CS contralateral e em (D) CS ipsolateral à lesão representando o aumento da imunorreatividade para astrócios em comparação com animal intacto. 
A

B
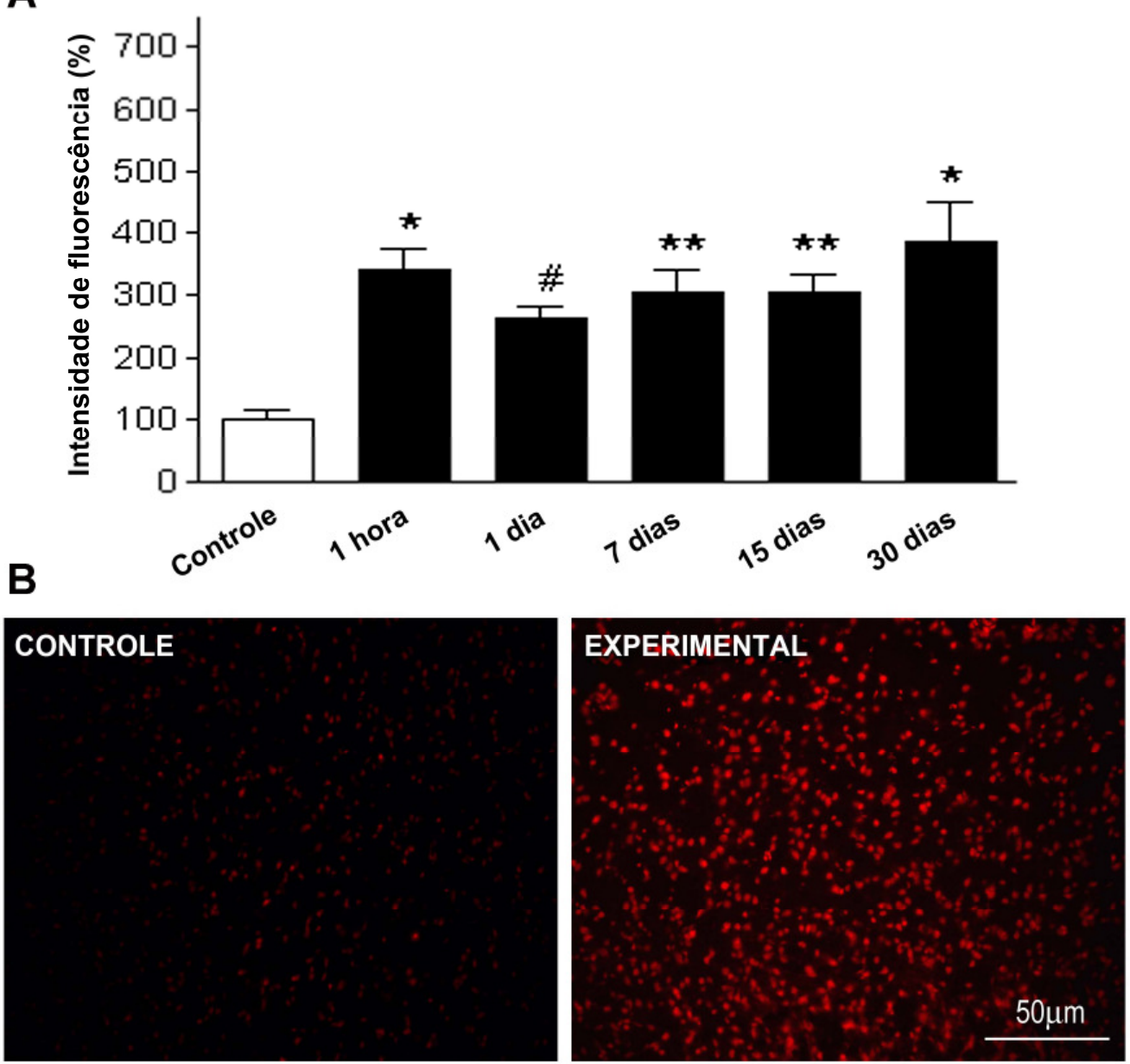

Figura 2.5 - Efeito da enucleação ocular sobre a geração de EROs no CS de ratos avaliados entre 1 hora e 30 dias pós-lesão. Os valores do gráfico representam a intensidade da fluorescência dos produtos derivados da oxidação da DHE (A). * $p<0,001 ;{ }^{* *} p<0,01$ e \#p $<0,05$ vs controle $(n=6)$. Em $B$, imagens digitais de cortes histológicos coronais de encéfalos de ratos ilustrando a geração de EROs no CS 1 dia após enucleação ocular. 
A

B
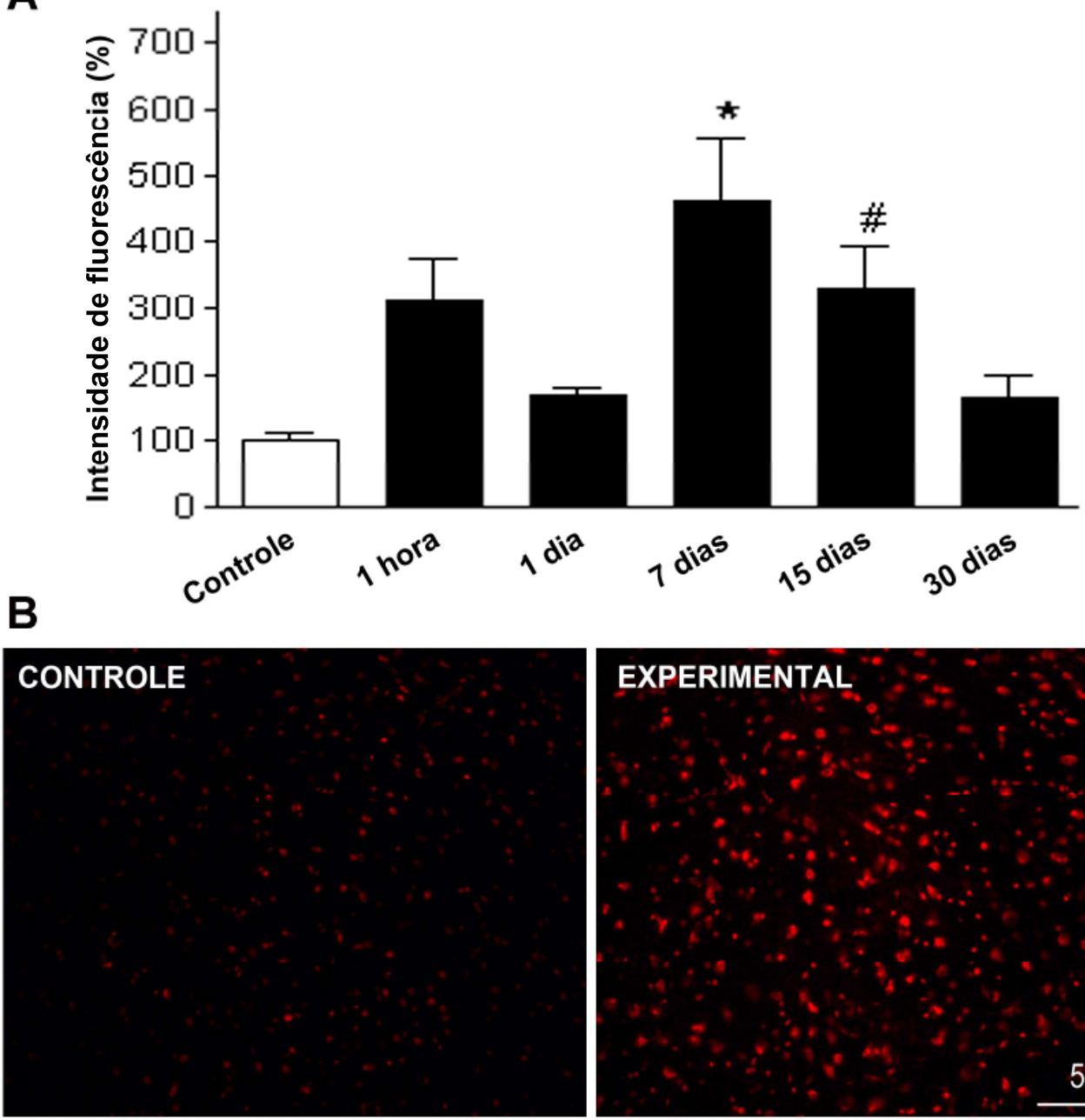

EXPERIMENTAL

$50 \mu \mathrm{m}$

Figura 2.6 - Efeito da enucleação ocular sobre a geração de EROs no GLD de ratos avaliados entre 1 hora 1 e 30 dias pós-lesão. O gráfico representa a intensidade da fluorescência dos produtos derivados da oxidação da $\operatorname{DHE}(A) .{ }^{*} p<0,001$ e \#p $<0,05$ vs controle $(n=6)$. Em $B$, imagens digitais de cortes histológicos coronais de encéfalos de ratos ilustrando a geração de EROs no GLD 7 dias após enucleação ocular. 
A

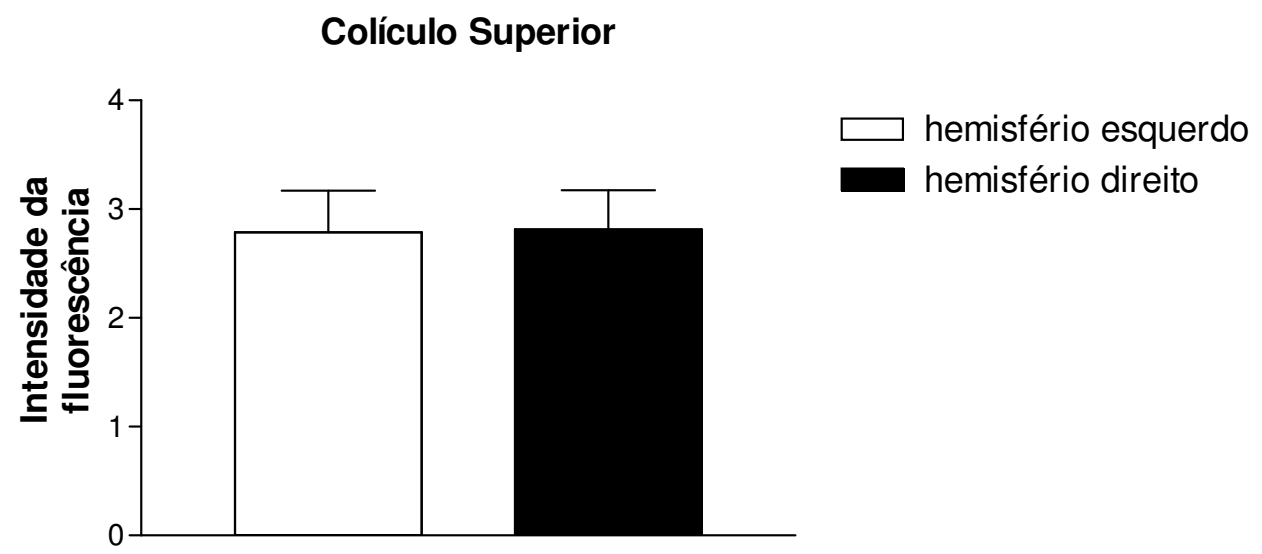

B
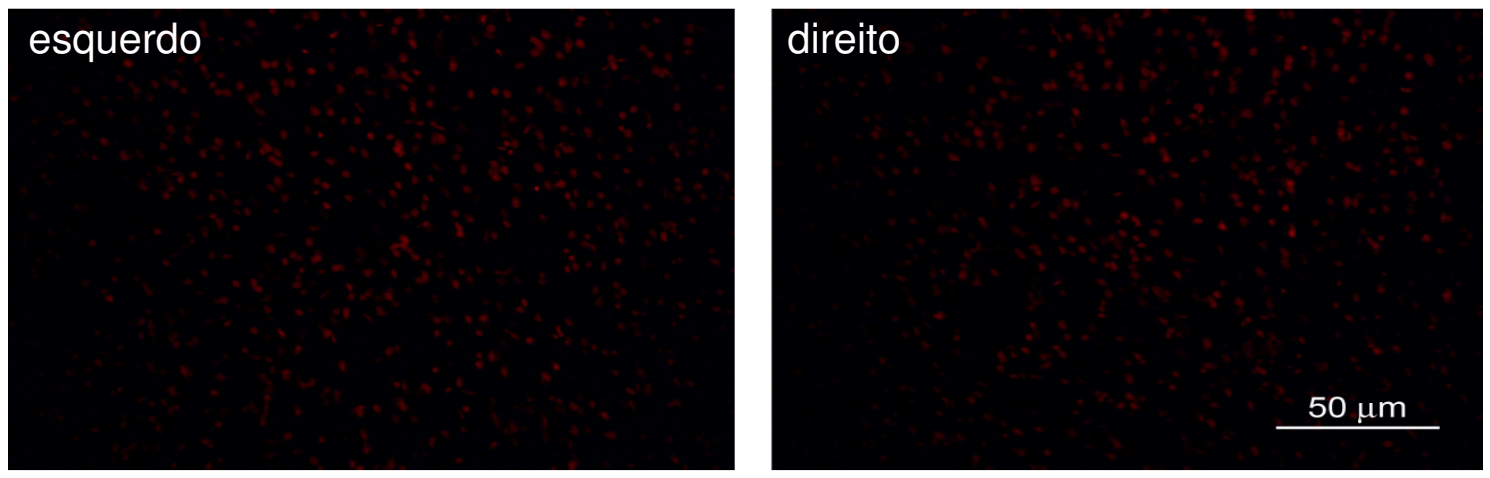

Figura 2.7 - Avaliação da geração de EROs no CS dos hemisférios cerebrais de animais do grupo controle. O gráfico em (A) representa a intensidade da fluorescência dos produtos derivados da oxidação da DHE $(n=5)$. Em B imagens digitais de cortes histológicos coronais de encéfalos de ratos ilustrando a geração de EROs no CS dos dois hemisférios cerebrais de animal do grupo controle. Não foi detectada variação na intensidade da fluorescência. 
A

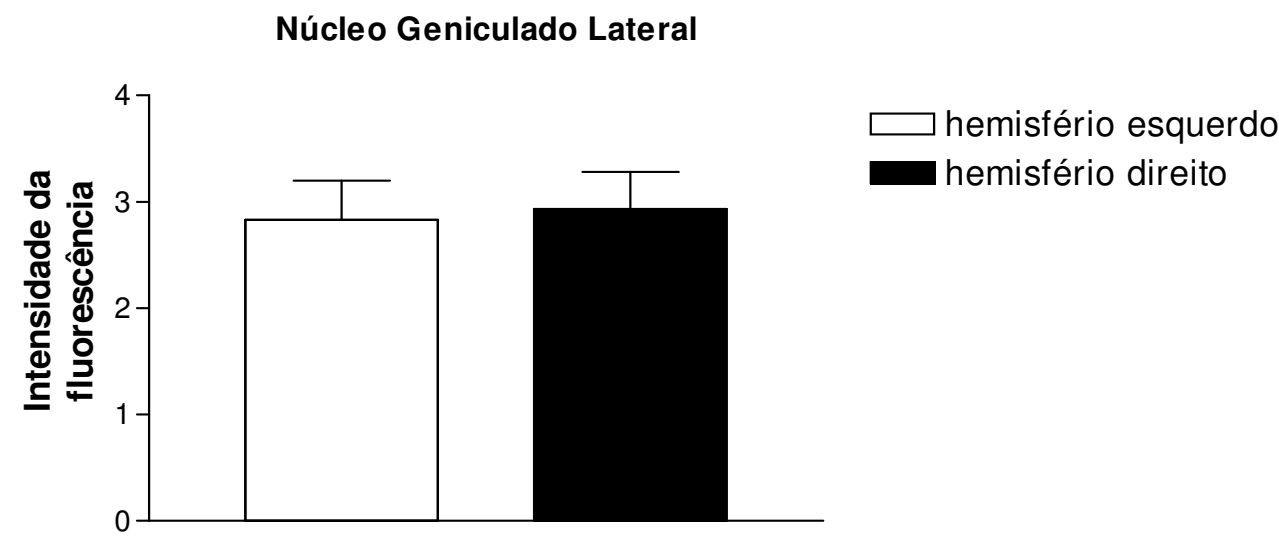

B
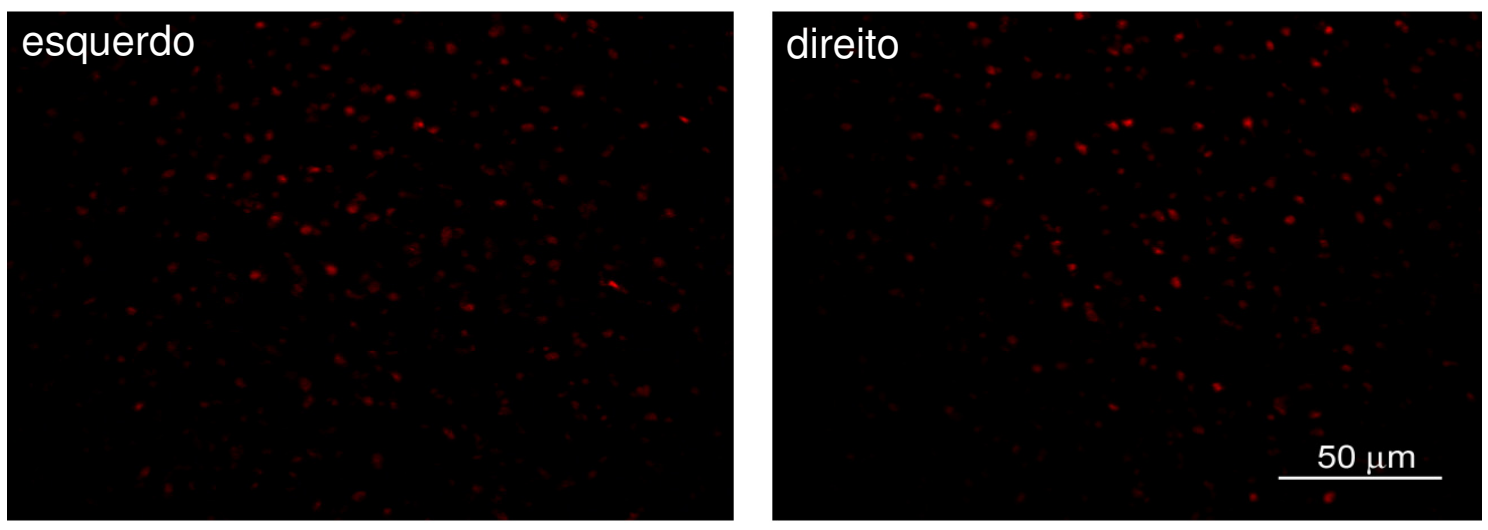

Figura 2.8 - Análise da geração de EROs no GLD dos hemisférios cerebrais de animais do grupo controle. O gráfico $(A)$ representa a intensidade da fluorescência derivada dos produtos de oxidação da $\operatorname{DHE}(n=5)$. Imagens digitais de cortes histológicos coronais de encéfalos de ratos ilustrando a geração de EROs no GLD dos dois hemisférios cerebrais de animal do grupo controle (B). Não foi detectada variação na intensidade da fluorescência. 
A

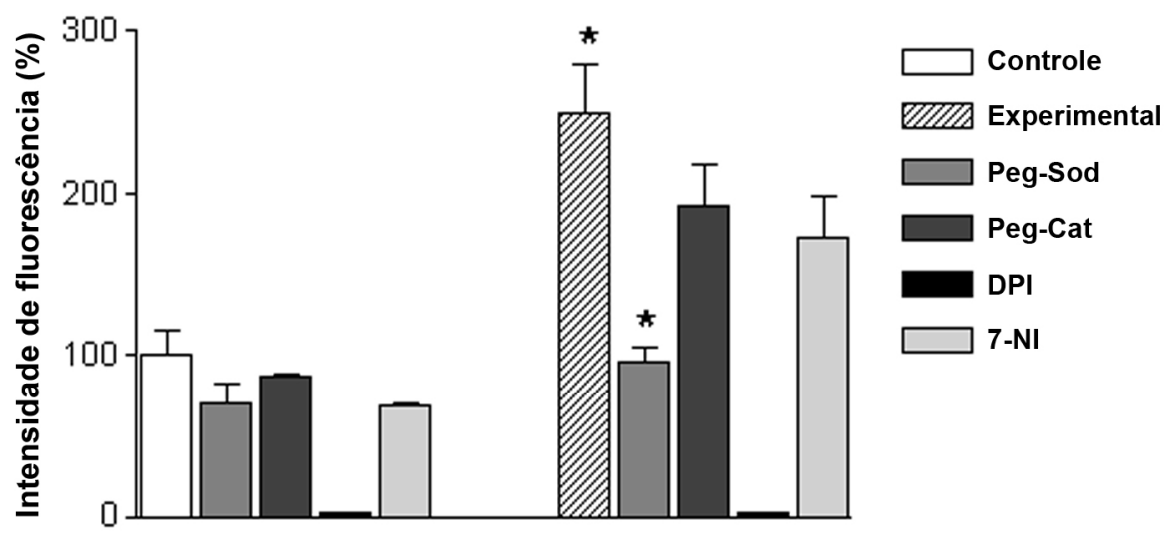

B

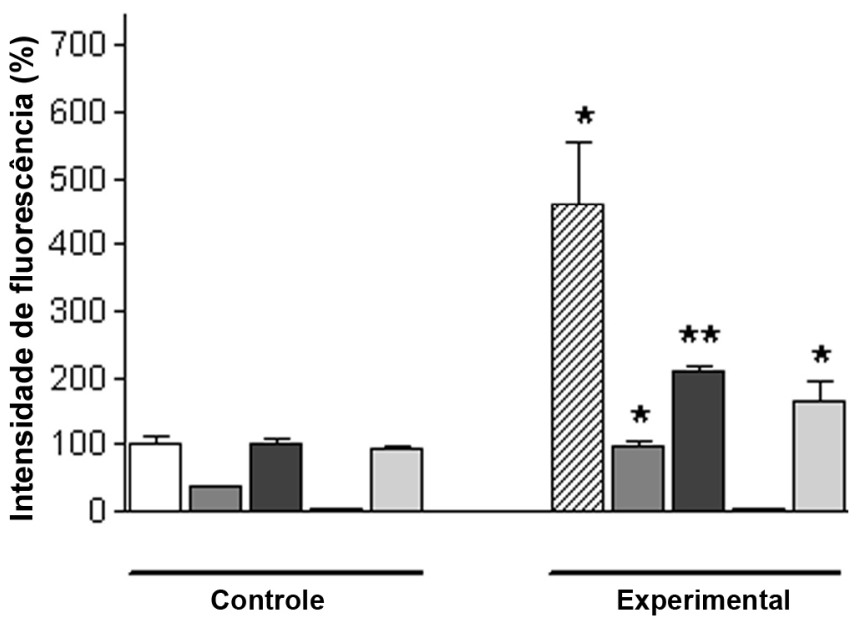

Figura 2.9 - Efeito da Peg-Sod (1000 U/ml), Peg-Cat (800 U/ml), DPI (10uM) e 7-NI (1mM) sobre a geração de EROs no CS (A) e no GLD (B) avaliados no $7^{\circ}$ dia pós-lesão. Os gráficos representam a intensidade da fluorescência derivada dos produtos de oxidação da $\operatorname{DHE}\left(n=4\right.$ a 5). ${ }^{*} p<0,001$ (controle vs experimental); $\# p<0,001$ (experimental vs experimental + Peg-Sod, experimental vs experimental $+7-\mathrm{NI}) \mathrm{e}^{* *} \mathrm{p}<0,01$ (experimental $v s$ experimental + Peg-Cat). 
A

CS

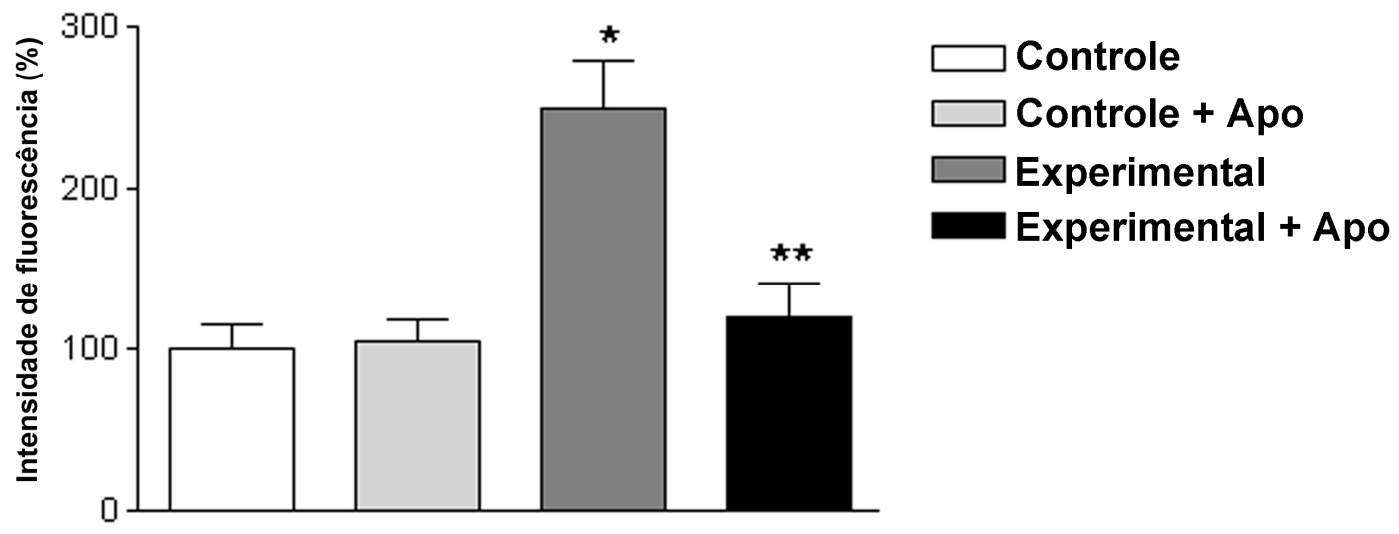

B

GLD

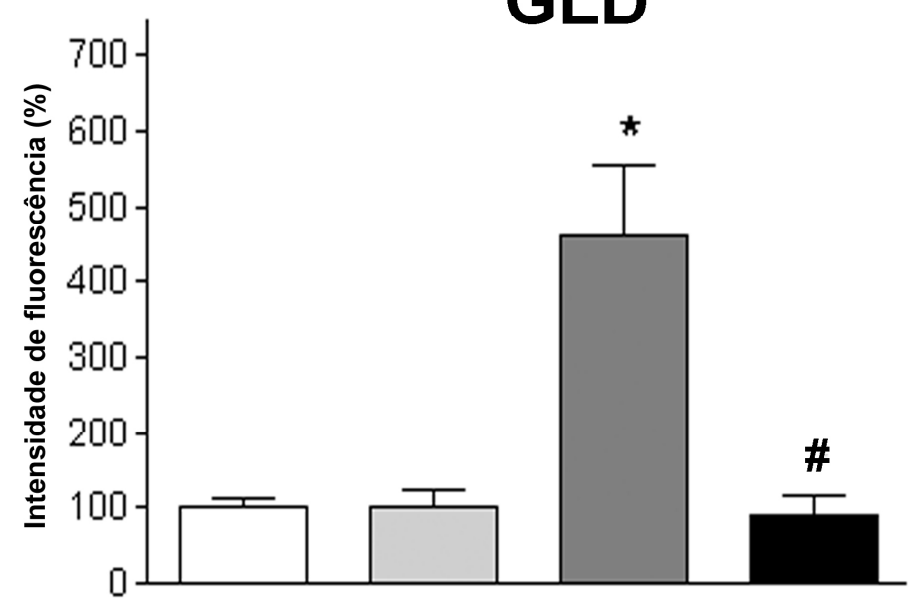

Figura 2.10 - Efeito do tratamento com apocinina $(12 \mathrm{mg} / \mathrm{kg} / \mathrm{dia}$ na água de beber durante 7 dias) sobre a geração de EROs no CS (A) e no GLD (B). Os gráficos representam a intensidade da fluorescência derivada dos produtos de oxidação da DHE $(n=5)$. ${ }^{*} p<0,001$ (controle vs experimental); ${ }^{* *} p<0,01$ (experimental vs experimental + apocinina) e \#p $<0,001$ (experimental vs experimental + apocinina). 


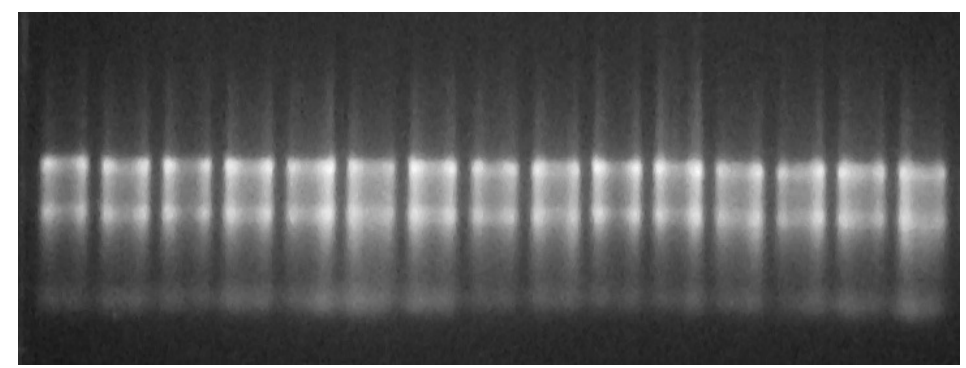

Figura 2.11 - Eletroforese em gel de agarose 1\%. Gel representativo da integridade das amostras de mRNA do CS. 
A

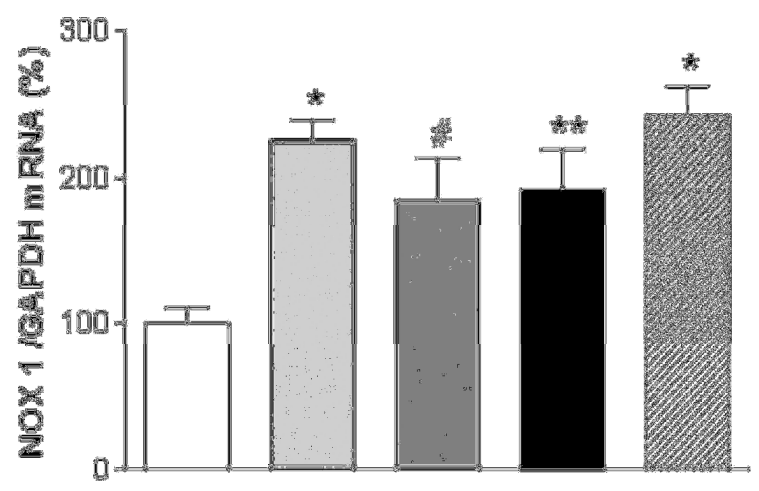

B

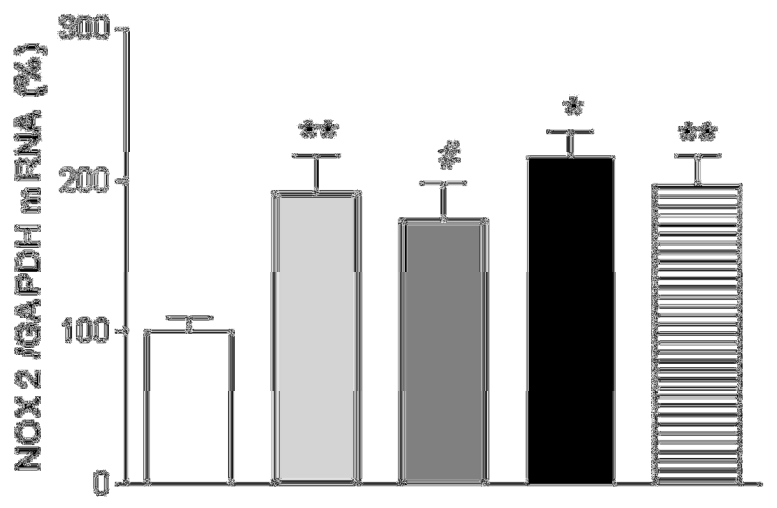

C

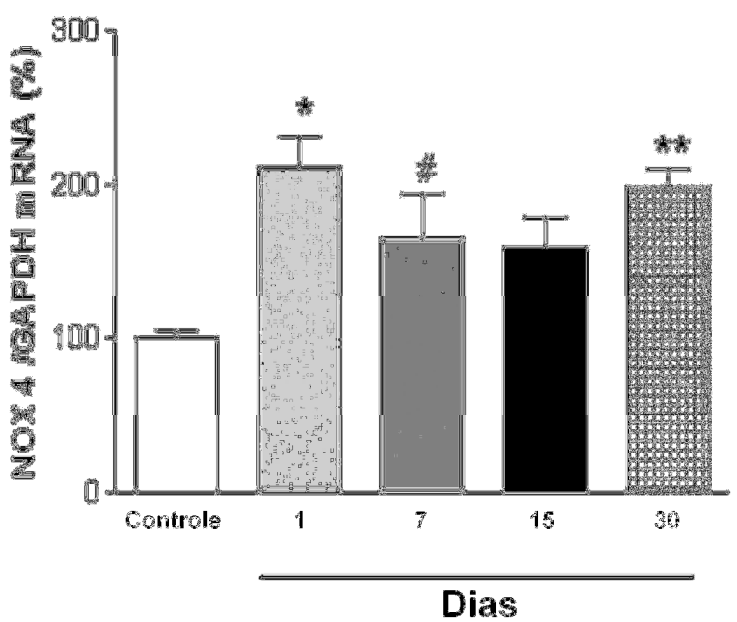

Figura 2.12 - Efeito da enucleação ocular sobre a expressão gênica de Nox 1(A), Nox 2 (B) e Nox 4 (C) no CS de ratos avaliados entre 1 e 30 dias após enucleação ocular por ensaios de RT-PCR. Os valores do gráfico representam a quantificação do mRNA das Noxes corrigido pelo GAPDH (controle interno). ${ }^{*} p<0,001 ;{ }^{* *} p<0,01$ e $\# p<0,05$ vs controle $(n=6$ a 8$)$. 


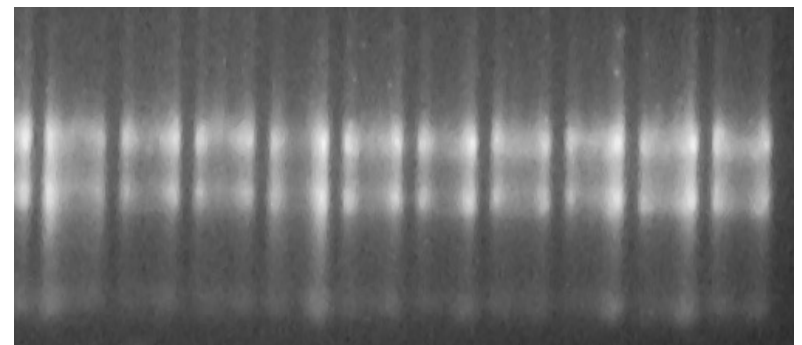

Figura 2.13 - Eletroforese em gel de agarose 1\%. Gel representativo da integridade das amostras de mRNA do tálamo. 
A

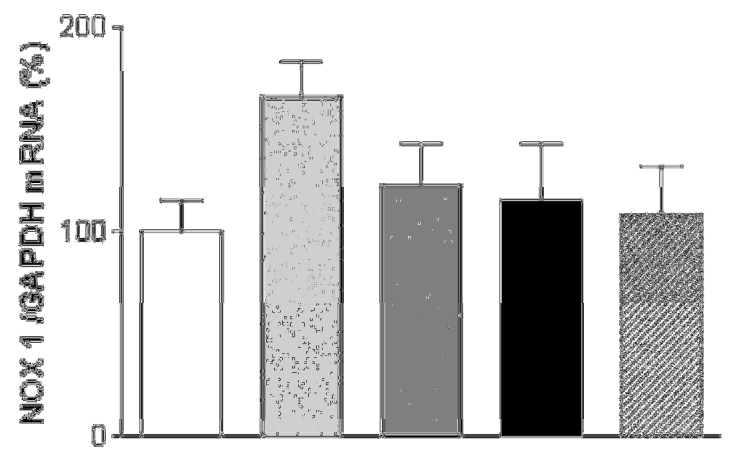

B

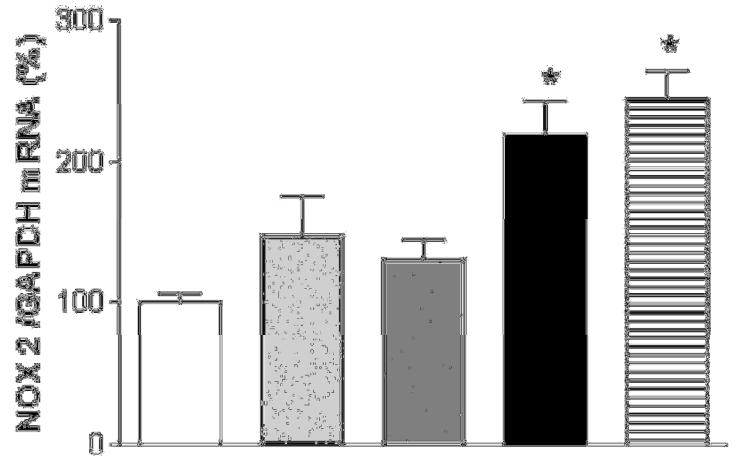

C

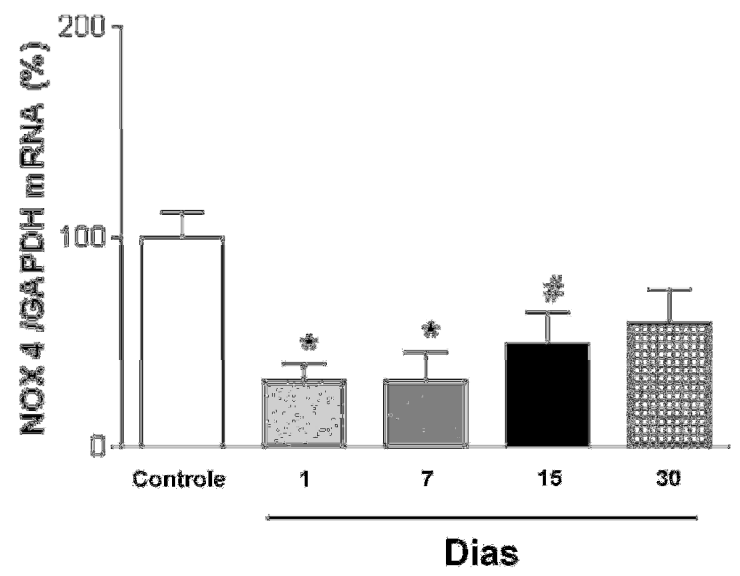

Figura 2.14 - Efeito da enucleação ocular sobre a expressão gênica de Nox $1(A)$, Nox 2 (B) e Nox 4 (C) no tálamo de ratos ratos avaliados entre 1 e 30 dias após enucleação ocular por ensaios de RT-PCR. Os valores do gráfico representam a quantificação do mRNA das Noxes corrigido pelo GAPDH (controle interno). ${ }^{*} p<0,001 ;{ }^{* *} p<0,01$ e \#p $<0,05$ vs controle $(\mathrm{n}=6$ a 8$)$. 
A

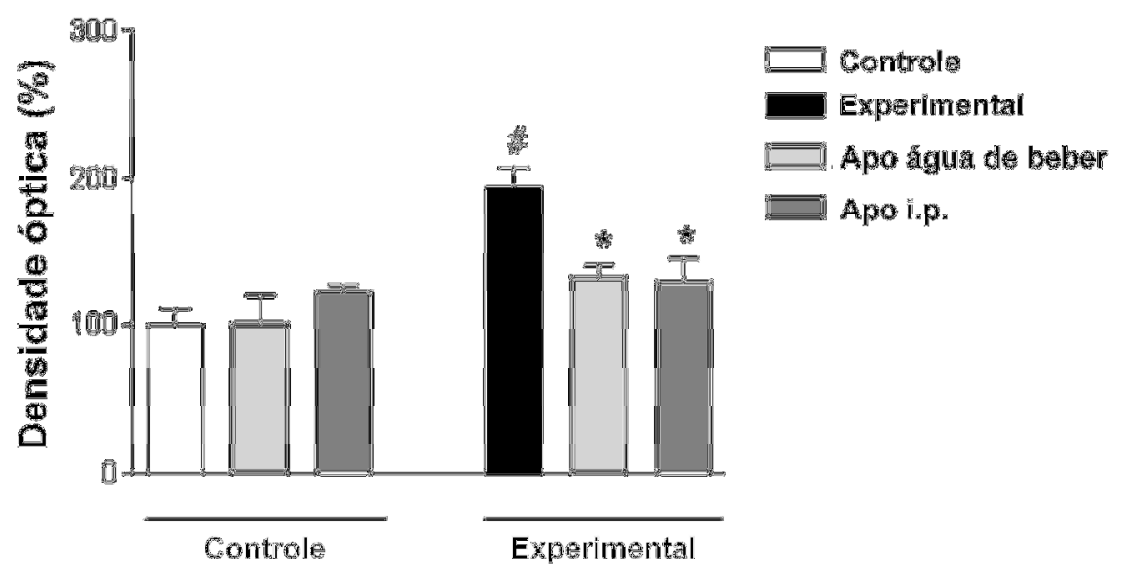

B

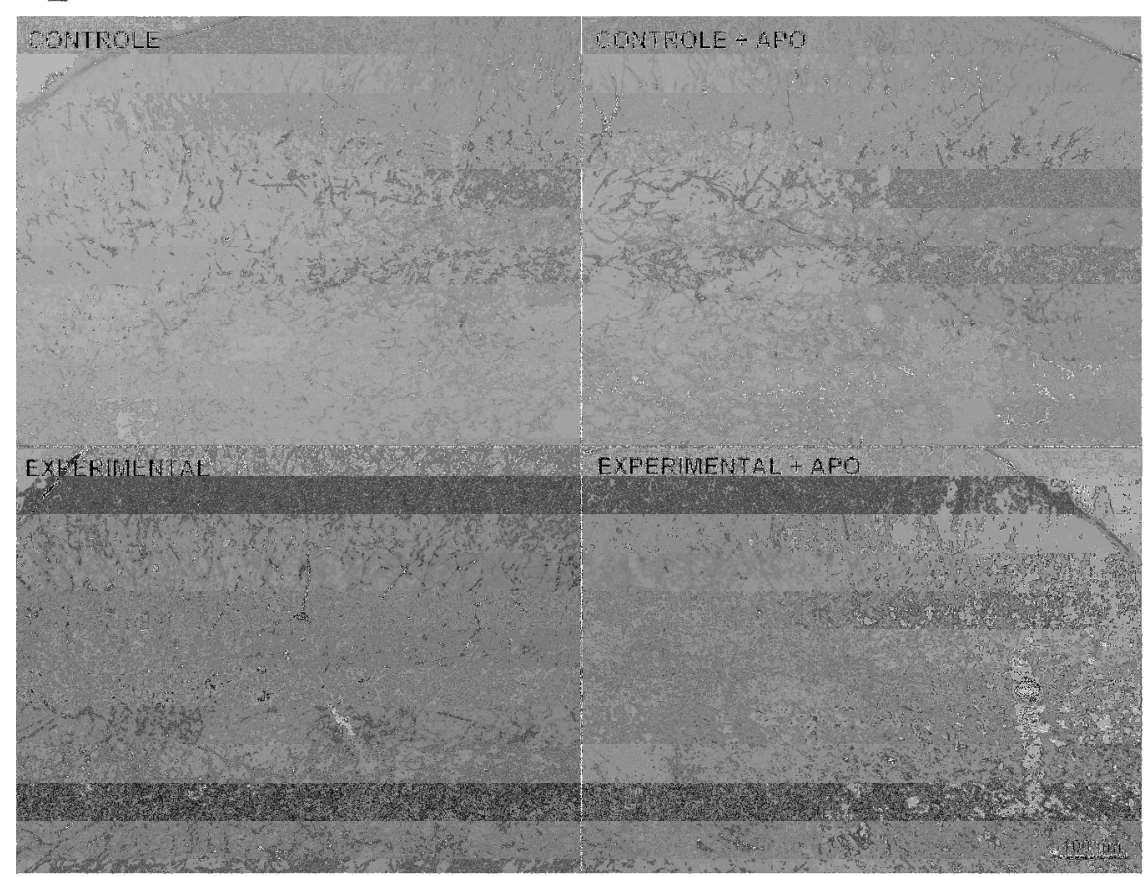

Figura 2.15 - Efeito da apocinina (12mg/kg/dia na água de beber ou $200 \mathrm{mg} / \mathrm{kg}$ i.p.) sobre a imunorreatividade para NFs no CS 7 dias após enucleação ocular. Os valores do gráfico $(A)$ representam a análise da densidade óptica $(n=5)$. Em $B$, imagens digitais de cortes coronais do encéfalo ilustrando o padrão de marcação para NFs em animais do grupo controle, controles tratados com apocinina (200 $\mathrm{mg} / \mathrm{kg}$ i.p.), experimentais e experimentais tratados com apocinina (200 mg/kg i.p.). Apo: apocinina. \#p <0,001(controle vs experimental) $e^{*} \mathrm{p}<0,001$ (experimental $v s$ apocinina na água de beber e experimental vs apocinina i.p.). 
A

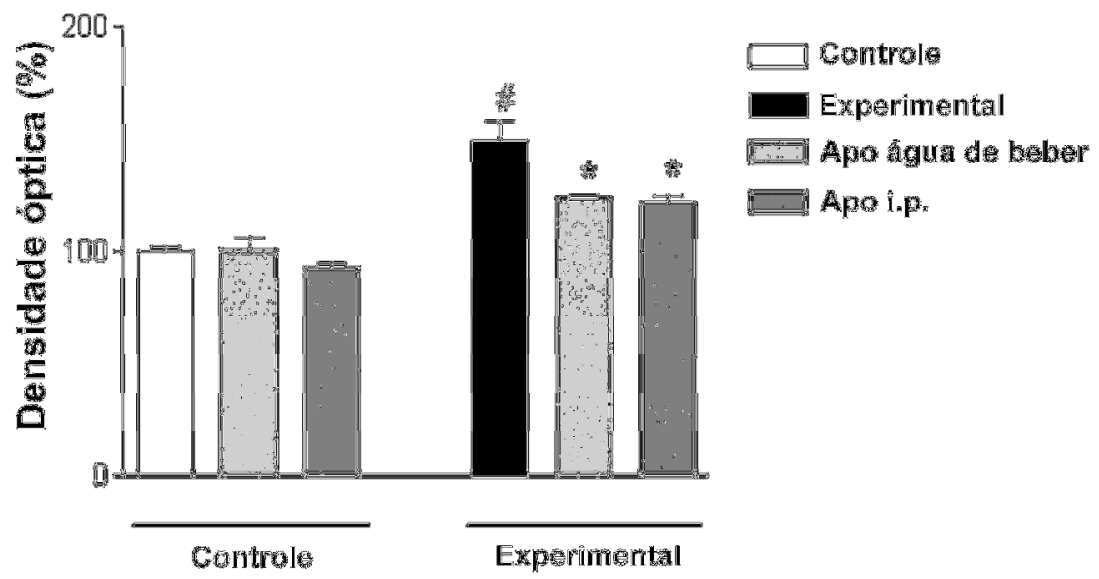

B

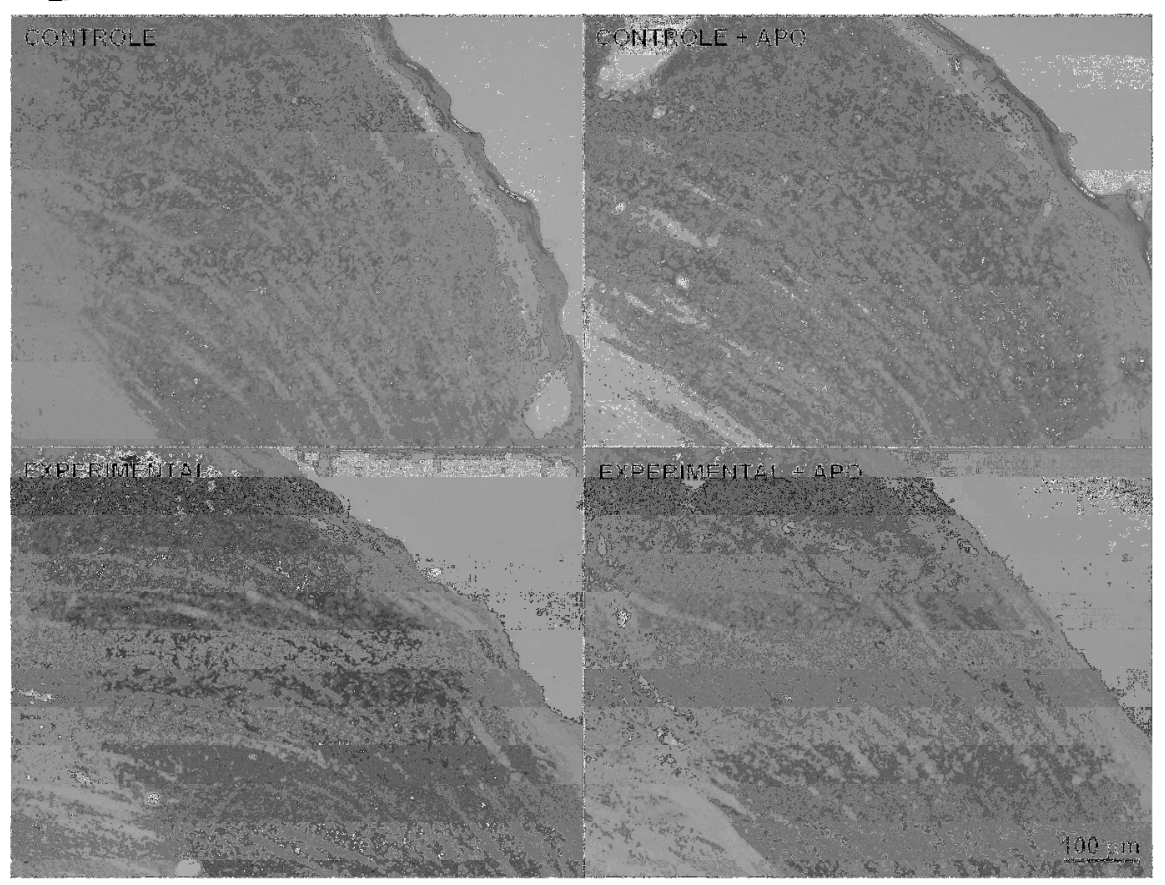

Figura 2.16 - Efeito da apocinina (12mg/kg/dia na água de beber ou $200 \mathrm{mg} / \mathrm{kg}$ i.p.) sobre a imunorreatividade para NFs no GLD 7 dias após enucleação ocular. Os valores do gráfico $(A)$ representam a análise da densidade óptica $(n=5)$. Em $B$, imagens digitais de cortes coronais do encéfalo ilustrando o padrão de marcação para NFs em animais do grupo controle, controles tratados com apocinina (200 $\mathrm{mg} / \mathrm{kg}$ i.p.), experimentais e experimentais tratados com apocinina (200 mg/kg i.p.). Apo: apocinina. \#p <0,001(controle vs experimental) $e^{*} \mathrm{p}<0,001$ (experimental vs apocinina na água de beber e experimental vs apocinina i.p.). 

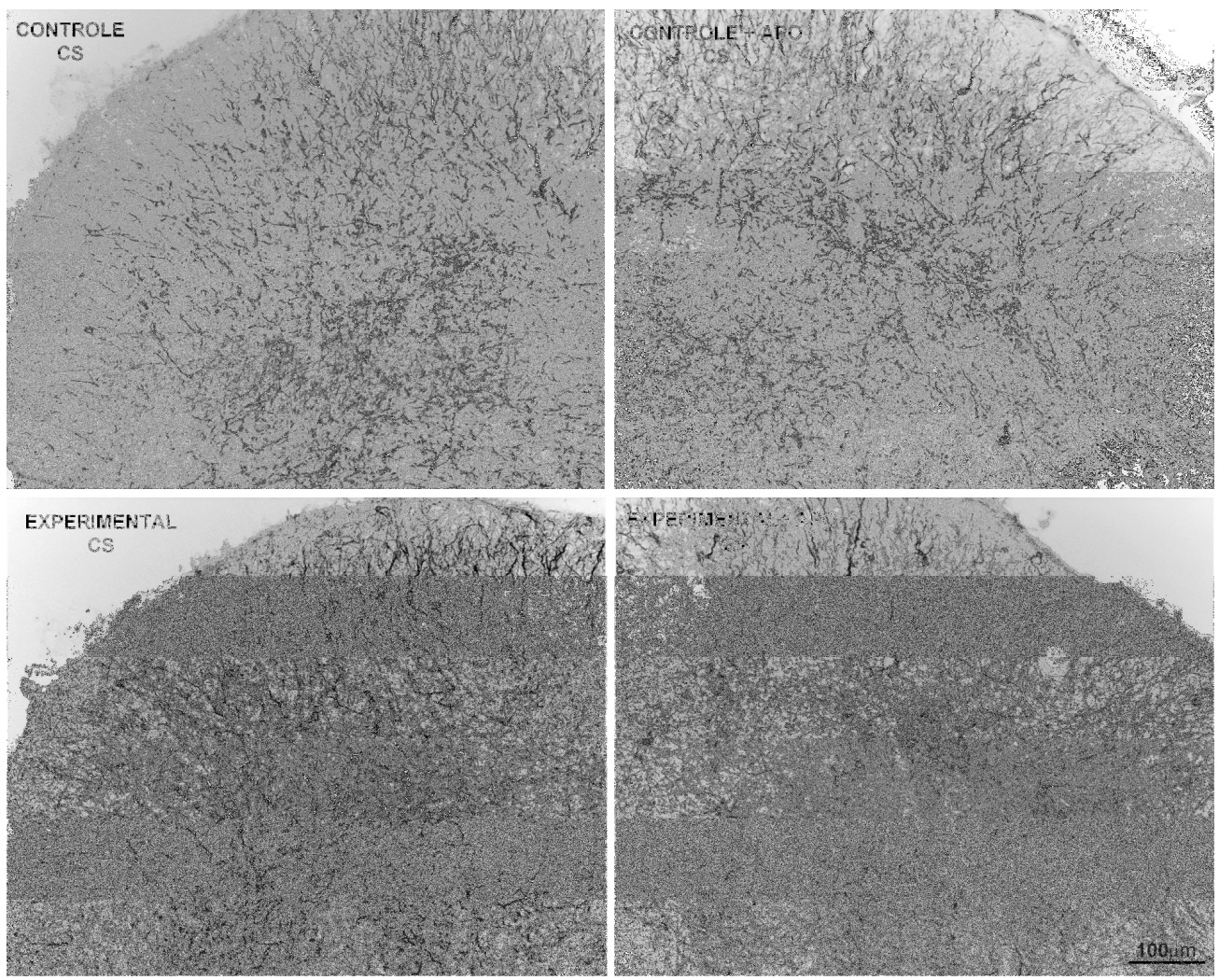

Figura 2.17 - Efeito da apocinina (12mg/kg/dia na água de beber) sobre a imunorreatividade para NFs no CS 30 dias após enucleação ocular. Imagens digitais de cortes coronais do encéfalo ilustrando o padrão de marcação para NFs em animais do grupo controle, controles tratados com apocinina, experimentais e experimentais tratados com apocinina. Apo: apocinina. 
A

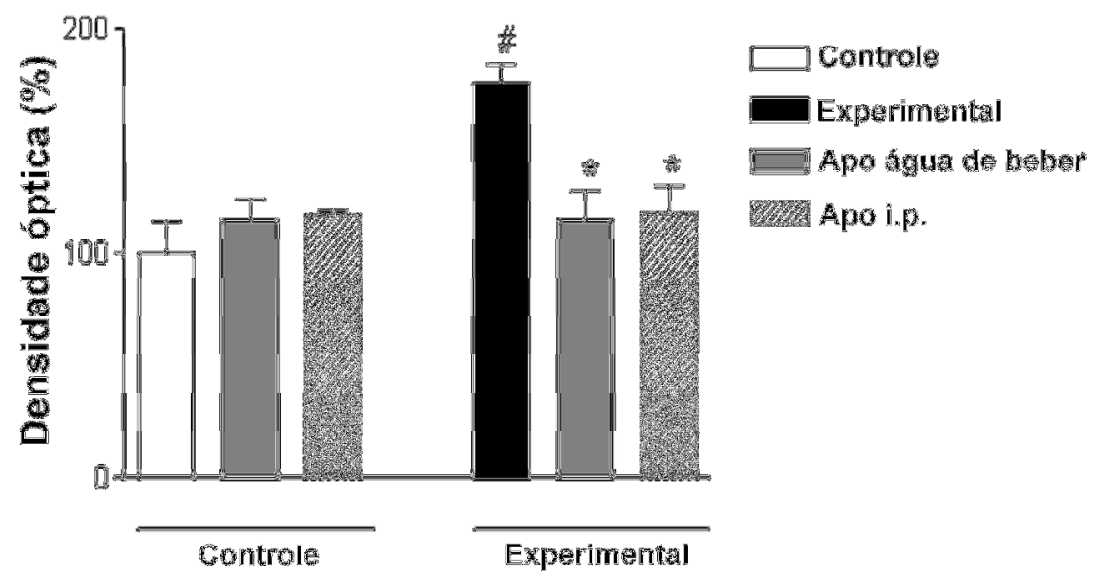

B

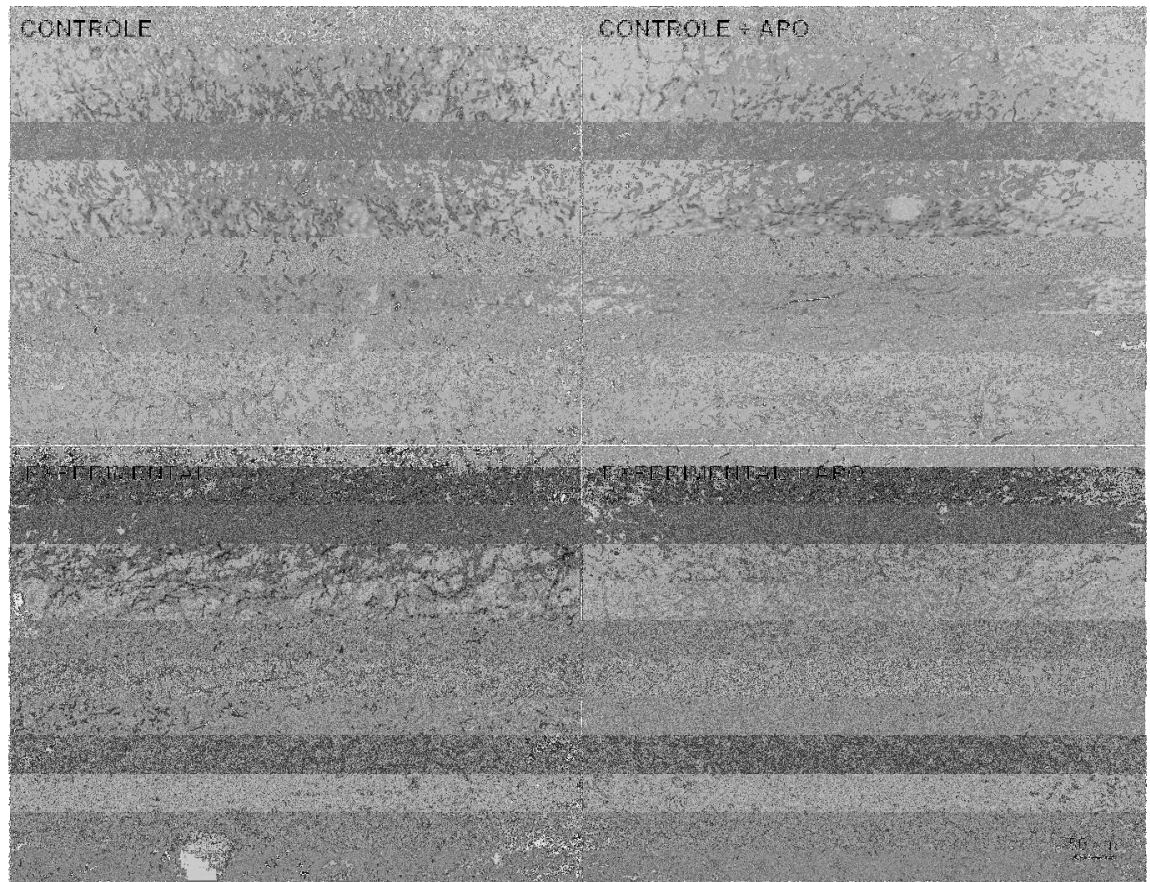

Figura 2.18 - Efeito da apocinina (12mg/kg/dia na água de beber ou $200 \mathrm{mg} / \mathrm{kg}$ i.p.) sobre a imunorreatividade para MAP-2 no CS 7 dias após enucleação ocular. Os valores do gráfico $(A)$ representam a análise da densidade óptica $(n=5)$. Em $B$, imagens digitais de cortes coronais do encéfalo ilustrando o padrão de marcação para MAP-2 em animais do grupo controle, controles tratados com apocinina (200 mg/kg i.p.), experimentais e experimentais tratados com apocinina (200 mg/kg i.p.). Apo: apocinina. \#p <0,001(controle vs experimental) $e^{*} \mathrm{p}<0,001$ (experimental $v s$ apocinina na água de beber e experimental vs apocinina i.p.). 
A

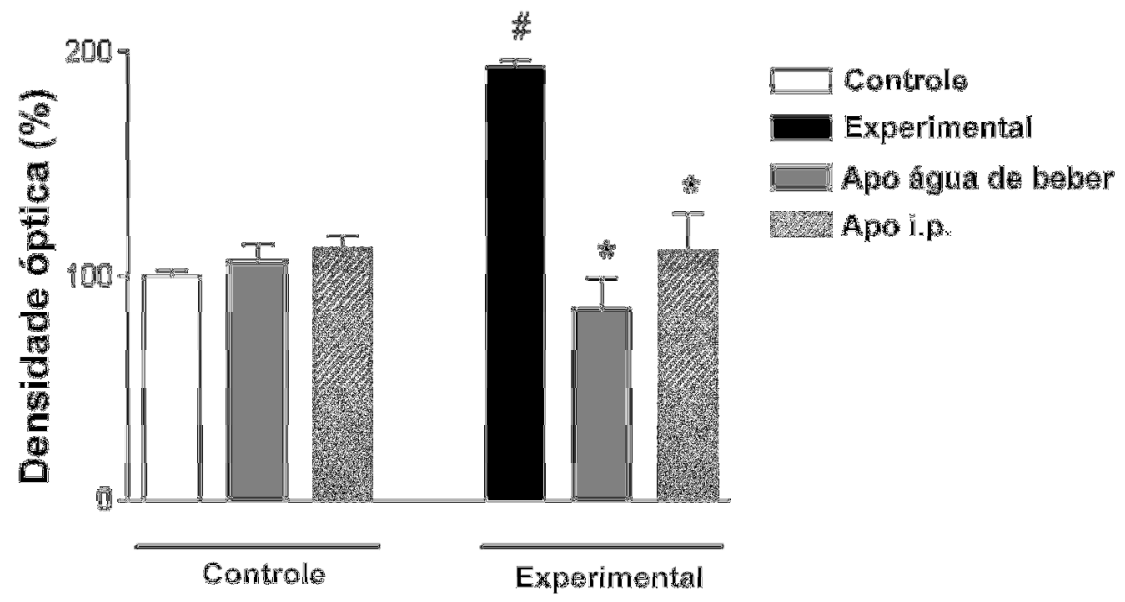

B

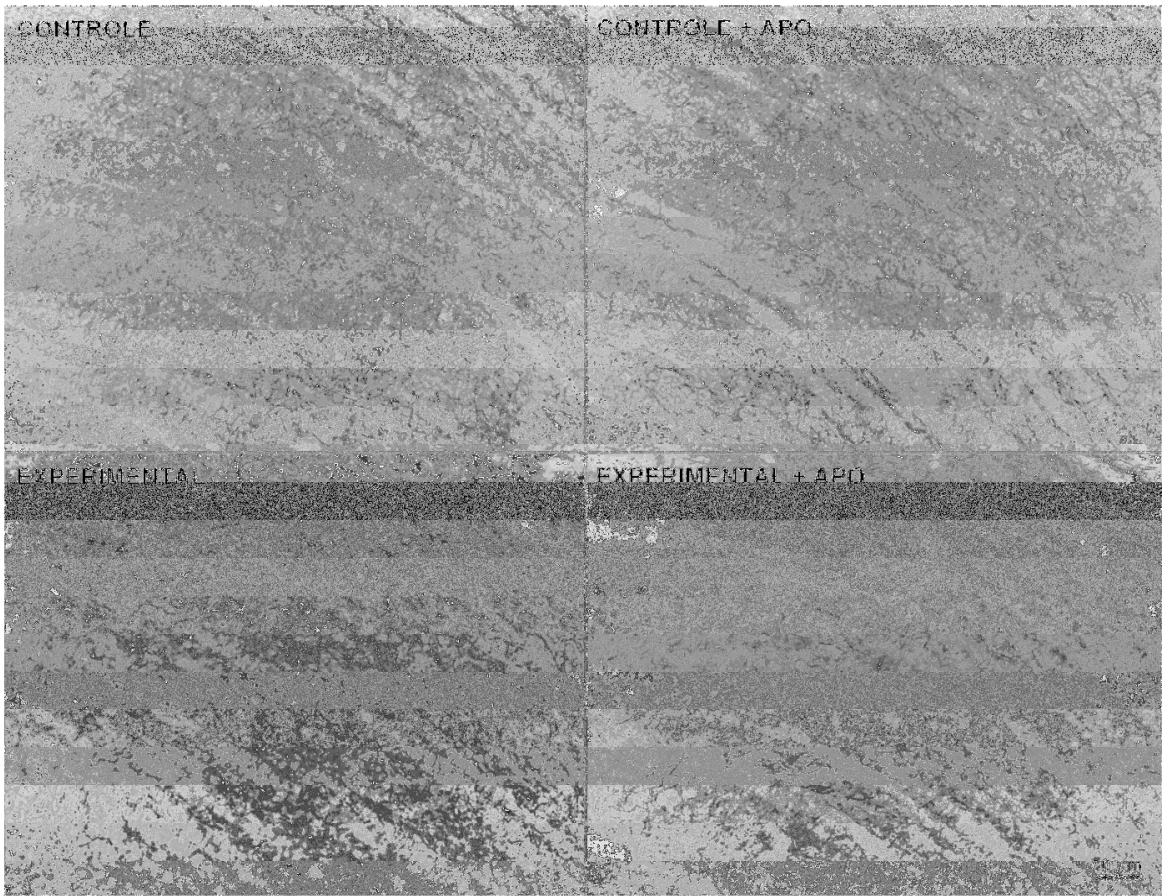

Figura 2.19 - Efeito da apocinina (12mg/kg/dia na água de beber ou $200 \mathrm{mg} / \mathrm{kg}$ i.p.) sobre a imunorreatividade para MAP-2 no GLD 7 dias após enucleação ocular. Os valores do gráfico $(A)$ representam a análise da densidade óptica $(n=5)$. Em $B$, imagens digitais de cortes coronais do encéfalo ilustrando o padrão de marcação para MAP-2 em animais do grupo controle, controles tratados com apocinina (200 mg/kg i.p.), experimentais e experimentais tratados com apocinina (200 mg/kg i.p.). Apo: apocinina. \#p <0,001 (controle vs experimental) e * $\mathrm{p}<0,001$ (experimental $v s$ apocinina na água de beber e experimental vs apocinina i.p.). 


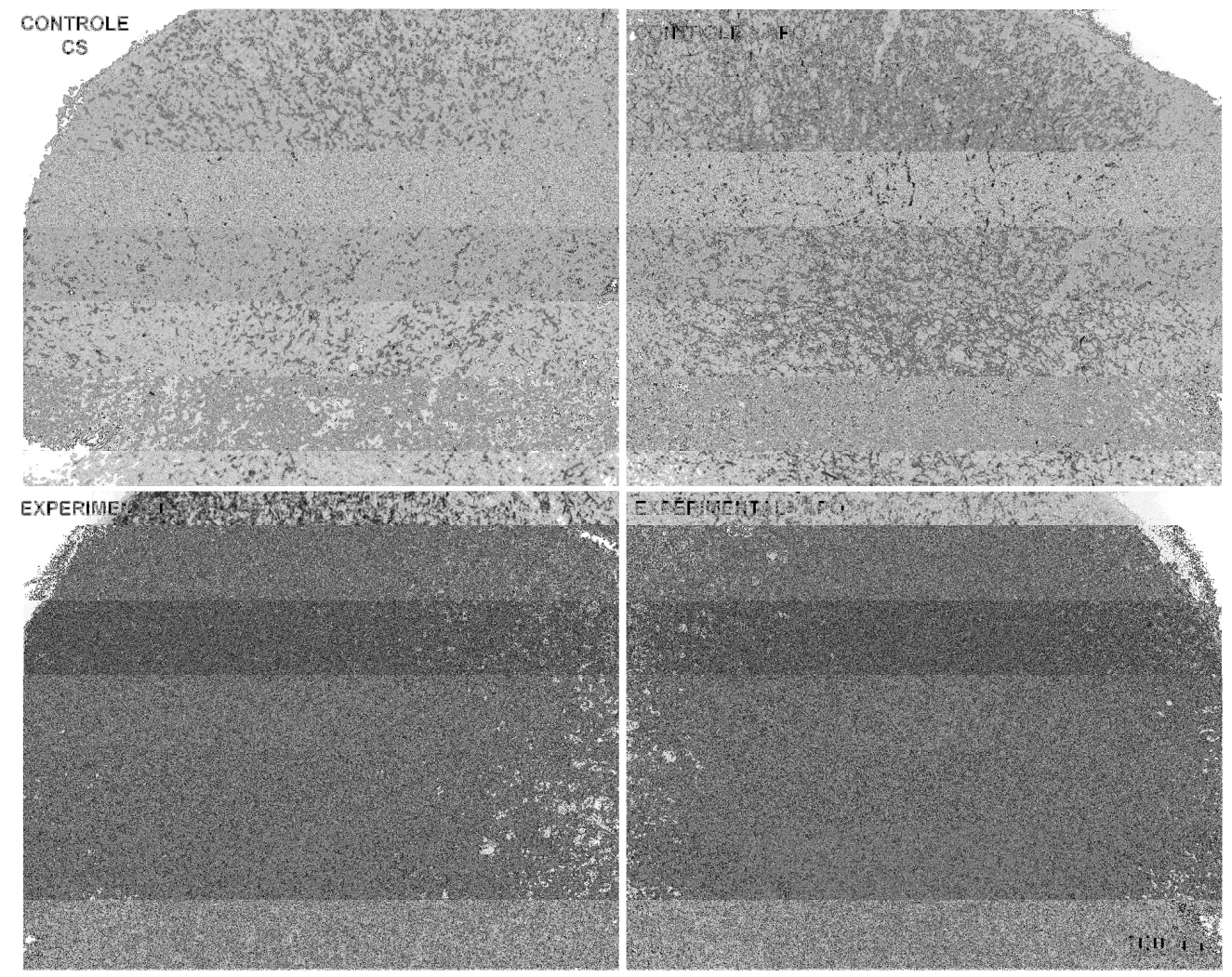

Figura 2.20 - Efeito da apocinina (12mg/kg/dia na água de beber) sobre a imunorreatividade para MAP-2 no CS trinta dias após enucleação ocular. Imagens digitais de cortes coronais do encéfalo ilustrando 0 padrão de marcação para MAP-2 em animais do grupo controle, controles tratados com apocinina, experimentais e experimentais tratados com apocinina. Apo: apocinina. 


\section{$\operatorname{cs}$}
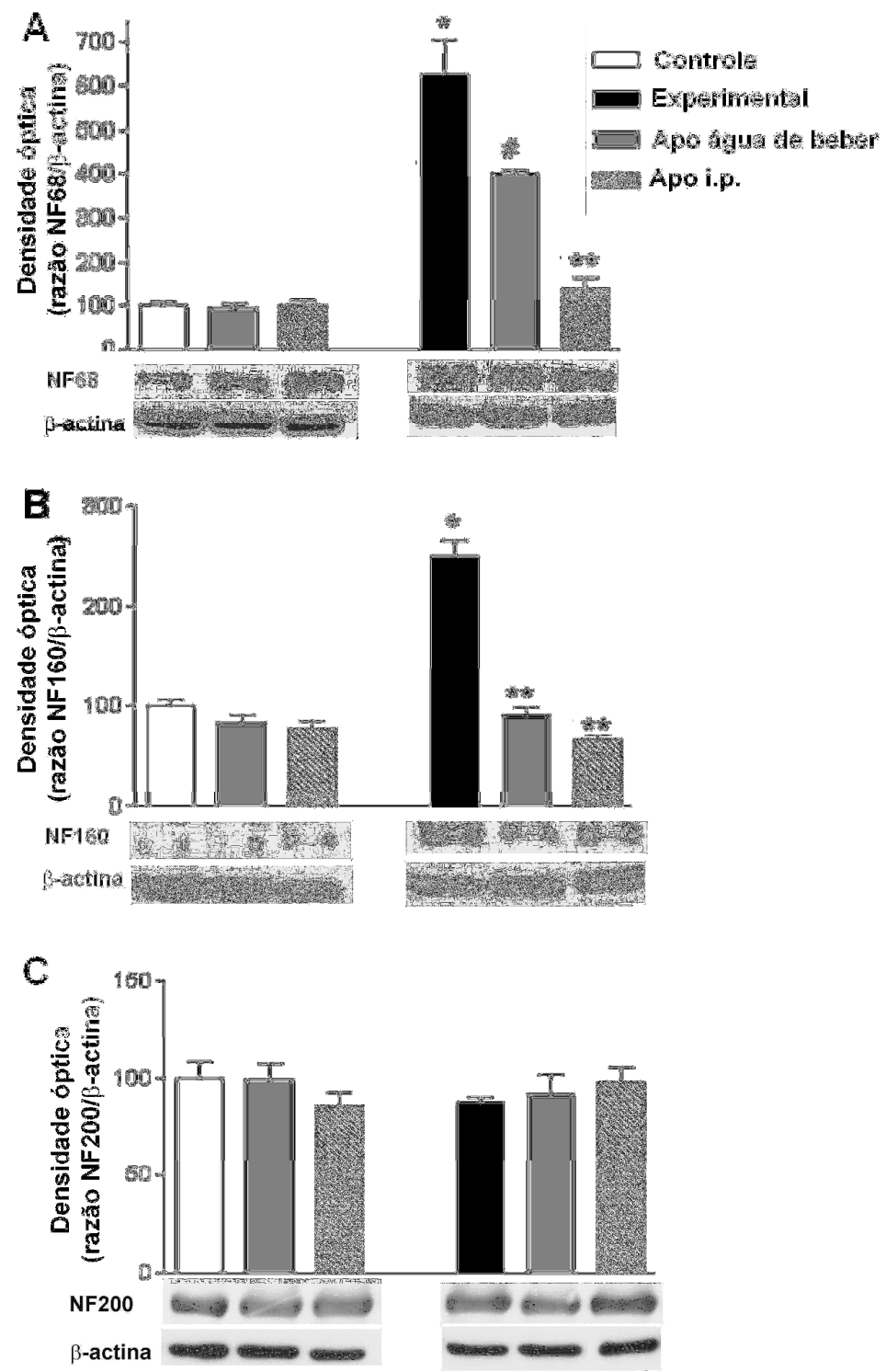

Figura 2.21 - Efeito da apocinina (12mg/kg/dia na água de beber ou $200 \mathrm{mg} / \mathrm{kg}$ i.p.) sobre a expressão proteica de NF68 (A), NF160 (B) e NF200 (C) no CS 7 dias após a enucleação ocular. Os gráficos representam a média da razão entre a densidade óptica das bandas das proteínas de interesse e da $\beta$-actina. NFs: neurofilamentos; NF68: neurofilamento 68kDa; NF160: neurofilamento $160 \mathrm{kDa}$ e NF200: neurofilamento 200kDa. ${ }^{*} p \quad<0,001$ (controle vs experimental), $\# p<0,01$ (experimental vs apocinina na água de beber) $e^{* *} p<0,001$ (experimental vs apocinina na água de beber $e$ experimental $v s$ apocinina i.p.). 


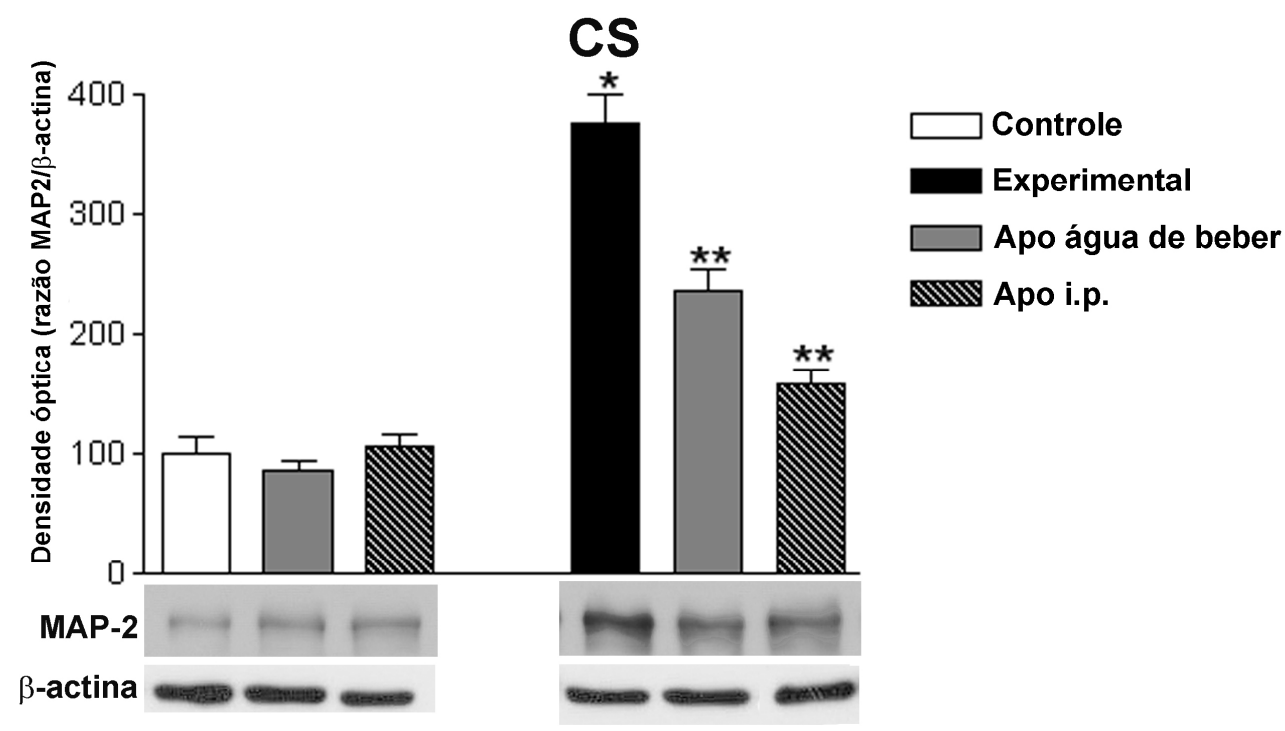

Figura 2.22 - Efeito da apocinina (12mg/kg/dia na água de beber ou $200 \mathrm{mg} / \mathrm{kg}$ i.p.) sobre a expressão proteica de MAP-2 no CS 7 dias após a enucleação ocular. O gráfico representa a média da razão entre a densidade óptica das bandas de MAP-2 e da $\beta$-actina. * $p$ $<0,001$ (controle vs experimental) e ${ }^{* *} p<0,001$ (experimental vs apocinina na água de beber e experimental $v s$ apocinina i.p.). 


\subsection{DISCUSSÃO}

A enucleação ocular em roedores é um bom modelo para o estudo dos efeitos da desaferentação, visto que cerca de 90 a 95\% das projeções retinianas cruzam a linha média e se projetam para o lado contralateral do encéfalo (DREHER et al., 1985). Desta maneira, aparentemente este modelo provê alguma vantagem para comparações, já que seria possível considerar um lado do encéfalo como experimental (contralateral à lesão) e outro como controle (ipsolateral à lesão). De fato, o lado do encéfalo contralateral à enucleação ocular parece ser mais afetado pela lesão. Além disso, de acordo com dados da literatura, tanto a retina quanto 0 nervo óptico contralaterais ao olho lesionado são freqüentemente utilizados como controles em estudos in vivo e in vitro (BODEUTSCH et al., 1999). Contudo, de acordo com alguns autores, a utilização do hemisfério cerebral ipsolateral à enucleação ocular como controle, bem como a utilização da retina e do nervo óptico contralaterais ao olho lesionado como controles, deve ser cuidadosamente reconsiderada por diversas razões (BODEUTSCH et al., 1999; SETKOWICZ et al., 2004; PANAGIS et al., 2005). Existem indícios, por exemplo, da existência de pequenas projeções recíprocas entre as retinas (projeção retino-retinal) (MULLER e HOLLANDER, 1988), as quais poderiam justificar a proliferação bilateral de células da glia na retina após a secção unilateral do nervo óptico (PANAGIS et al., 2005). Além disso, de acordo com Bodeutsch e colaboradores, a lesão da microvasculatura do nervo óptico poderia levar a uma lesão vascular generalizada (BODEUTSCH et al., 1999). Alternativamente, a comissura intertectal, além de interações córticocoliculares e córtico-corticais poderiam desencadear respostas em ambos os hemisférios cerebrais após a lesão, provavelmente mais pronunciadas no lado do encéfalo que recebe maior parte das projeções retinianas. Considerando ainda 0 CGL, esta estrutura sabidamente recebe aferências contra e ipsolaterais do CS (NAUTA e VAN STRAATEN, 1947; HAYHOW, 1962).

A despeito de todos os fatores que poderiam desencadear respostas em ambos os hemisférios cerebrais após a enucleação ocular, foram descritas células 
ganglionares que empregam um fotopigmento conhecido como melanopsina, capazes de emitir projeções bilateralmente simétricas para 0 núcleo supraquiasmático (HATTAR et al., 2006; HANKINS et al., 2008). Todas estas evidências relativamente recentes, além de algumas observações experimentais em nosso laboratório de pesquisa, foram determinantes para a escolha da utilização de animais intactos como controles no presente trabalho.

Até o final do século $X X$ as EROs e ERNs eram consideradas agentes extremamente nocivos à vida. No final deste século, a descoberta de que o NO atua como um vasodilatador nas paredes internas de veias e artérias rendeu aos pesquisadores americanos Louis Ignarro, Robert Furchgott e Ferid Murad o Prêmio Nobel de Medicina em 1998. Desde então, vários conceitos foram reformulados como o de que espécies reativas não poderiam agir como sinalizadores intracelulares por serem moléculas transientes. Atualmente sabe-se que EROs podem intermediar desde circuitos de sinalização fisiológicos e patológicos até lesões a constituintes celulares como a oxidação de proteínas, lipídios e até do DNA. Por esta razão, ao longo dos últimos anos, vários trabalhos tentam estabelecer relações entre a natureza química das EROs, suas funções fisiológicas e seu papel na neurodegeneração (OHARA, 2006; FATOKUN et al., 2008).

Datam da década de 80 os primeiros estudos segundo os quais EROs seriam capazes de agir como moléculas sinalizadoras no encéfalo (PELLMAR, 1986; PELLMAR, 1987). De acordo com estes trabalhos, EROs poderiam modular a liberação de dopamina e glutamato no estriado, córtex cerebral e hipocampo, por exemplo (GILMAN et al., 1992; JOSEPH et al., 1996). Estudos ainda mais recentes sugerem que EROs são importantes moléculas sinalizadoras, requeridas na formação de memória e plasticidade sináptica (KISHIDA e KLANN, 2007). Portanto, é claramente necessária uma compreensão mais elaborada dos complexos mecanismos celulares que alteram a homeostase redox em modelos de lesão do sistema nervoso central. No presente trabalho, uma série de análises bioquímicas e morfológicas foram conduzidas para investigar a produção e o impacto da geração de EROs em áreas visuais primárias após enucleação ocular. 
É possível quantificar a produção in situ de EROs utilizando-se marcadores fluorescentes como a DHE ou o DCF-DA (diacetato de dichlorodihidrofluoresceína). Após difundir-se pela membrana celular, a DHE é oxidada e, como produtos desta oxidação, são formados dois compostos fluorescentes: o etídio e o 2-hidroxietídio (EOH) (GARBETT et al., 2004). Estudos in vitro comprovaram que a formação do $\mathrm{EOH}$ ocorre preferencialmente pela oxidação da DHE por $\mathrm{O}_{2}{ }^{--}$, mas também pode ocorrer, em menor proporção, na presença de peroxinitrito/ $\mathrm{CO}_{2}$ ou reagente de Fenton $\left(\mathrm{Fe}^{2+}-\mathrm{EDTA} / \mathrm{H}_{2} \mathrm{O}_{2}\right)$. Já a formação de etídio parece correlacionar-se com a atividade de peroxidases e hemeproteínas, cujo substrato é o $\mathrm{H}_{2} \mathrm{O}_{2}$. Ambos os produtos de oxidação interagem fortemente com os grupos fosfato do DNA e, em seguida, intercalam-se a ele, emitindo o sinal da fluorescência (ZHAO et al., 2003; FINK et al., 2004; ZHAO et al., 2005).

Neste trabalho, foi observado o aumento da geração de EROs no CS e no GLD do tálamo em diferentes períodos após enucleação ocular. Considerando que não existem indícios de morte celular por apoptose ou necrose em estruturas retinorrecipientes entre 1 e 30 dias após a lesão (MATOS, 2007), nossos resultados sugerem que o aumento da geração de EROs observado neste trabalho deve refletir o envolvimento destas espécies nos fenômenos de plasticidade sináptica decorrentes da remoção do globo ocular, de modo a promover a reorganização funcional das estruturas retinorrecipientes.

De acordo com Behrens e colaboradores (BEHRENS et al., 2007), o tratamento por 2 dias consecutivos com quetamina (30 mg/kg), o anestésico utilizado no presente estudo, aumentou a geração de EROs, além da expressão protéica de Nox 2 e de p22 ${ }^{\text {PHOX }}$ no córtex cerebral de ratos. Em nossos experimentos, a dose utilizada de quetamina ( $50 \mathrm{mg} / \mathrm{kg}$ ) não foi capaz de aumentar a geração de EROs em estruturas retinorrecipientes de animais intactos.

Como o resultado obtido com a avaliação dos produtos de oxidação da DHE é a soma da fluorescência total de cada um dos produtos, etídio e EOH, este método não nos possibilita identificar que tipo de EROs foram geradas após a lesão. Além disso, sabemos que a DHE pode ser oxidada por outras espécies que não o $\mathrm{O}_{2} \bullet$ e 0 
$\mathrm{H}_{2} \mathrm{O}_{2}$ (ZHAO et al., 2003; FINK et al., 2004). Desta forma, alguns dos experimentos realizados neste trabalho foram conduzidos com a finalidade de avaliar a geração de EROs mediante a pré-incubação do tecido com enzimas antioxidantes, inibidores da nNOS (7-NI) e de flavoenzimas.

$\mathrm{Na}$ década de 60, McCord e Fridovich relataram pela primeira vez a presença de SOD, uma enzima abundante, filogeneticamente conservada e amplamente distribuída em tecidos animais. Esta foi a primeira evidência concreta da produção contínua de EROs em organismos vivos. Esta enzima é capaz dismutar o $\mathrm{O}_{2}$-- para $\mathrm{H}_{2} \mathrm{O}_{2}$ e $\mathrm{O}_{2}$ (MCCORD e FRIDOVICH 1969; OHARA, 2006). Com a finalidade de determinar se o aumento da fluorescência dos produtos de oxidação da DHE estava relacionado à geração do $\mathrm{O}_{2} \bullet-$, alguns experimentos foram realizados mediante a incubação do tecido com PEG-SOD. A inibição da geração no CS e no GLD pela PEG-SOD demonstra que a fluorescência observada é, pelo menos em parte, derivada do $\mathrm{O}_{2} \cdot$.

Para determinar se o aumento da oxidação da DHE após a enucleação ocular também estava relacionado à geração de $\mathrm{H}_{2} \mathrm{O}_{2}$, alguns experimentos foram conduzidos através da incubação do tecido PEG-CAT. A catalase é uma enzima que decompõe $\circ \mathrm{H}_{2} \mathrm{O}_{2}$ em $\mathrm{H}_{2} \mathrm{O}$ e $\mathrm{O}_{2}$. A PEG-CAT inibiu significativamente a geração apenas no GLD, o que indica a presença de $\mathrm{H}_{2} \mathrm{O}_{2}$ nesta estrutura, além de sugerir diferenças quanto à identidade das espécies geradas entre o GLD e o CS.

Muito embora o aumento da síntese de NO seja relacionado a várias patologias, o NO é capaz de desempenhar inúmeras funções fisiológicas (LIPTON, 1999; ESPLUGUES, 2002). Neste trabalho a adição de 7-NI (um inibidor não seletivo das isoformas da NOS) aos cortes inibiu significativamente o sinal da fluorescência no GLD. Estes dados corroboram os resultados obtidos por Chacur e colaboradores, segundo os quais a enucleação ocular aumenta a expressão da nNOS em estruturas retinorrecipientes. De acordo com estes autores, o aumento da expressão de nNOS deve contribuir para a intensa atividade plástica das estruturas relacionadas com 0 processamento de informação visual (BATISTA, 2006; CHACUR et al., 2006). 
No presente estudo, a incubação do CS e do GLD com DPI, um inibidor da NADPH oxidase e de oxidases mitocondriais (GERICH et al., 2006) aboliu completamente a geração de EROs. Estes resultados forneceram os primeiros indícios da participação da NADPH oxidase como fonte geradora de EROs no CS e

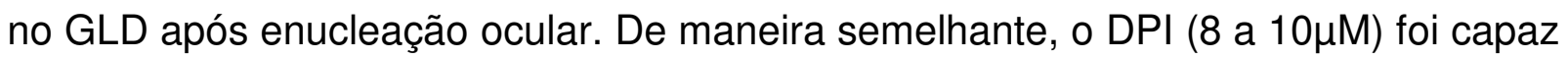
de inibir significativamente a geração de EROs por fluorescência dos produtos de oxidação da DHE em neutrófilos isolados do sangue de mamíferos (HE et al., 2005; RINALDI et al., 2007).

Neste mesmo sentido, o tratamento dos animais com apocinina, um inibidor da translocação das subunidades citoplasmáticas da NADPH oxidase para a membrana celular e, portanto, da ativação do complexo enzimático, inibiu significativamente a geração de EROs tanto no CS quanto no GLD. O efeito da apocinina foi compatível com os resultados obtidos recentemente por O'Donnell e colaboradores (MASOOD et al., 2008). De acordo com estes autores, o tratamento com apocinina (3mg/kg i.p.), administrada 30 minutos antes do inicio do tratamento com L-buthionine-(S,R)-sulfoximine (300 mg/kg i.p.), um agente indutor de estresse oxidativo, reverteu a geração de EROs no hipotálamo e na amígdala de camundongos observada pela fluorescência do DCF-DA, assim como alterações comportamentais induzidas pelo tratamento. $O$ tratamento com apocinina $(5 \mathrm{mg} / \mathrm{dia}$ por 7 dias na água de beber) também inibiu significativamente a geração de EROs pela fluorescência dos produtos de oxidação da DHE nas regiões pré e infra-limbicas de animais tratados com quetamina (30 mg/kg por dois dias consecutivos), de acordo com o que foi observado por Behrens e colaboradores (BEHRENS et al., 2007).

Dentre as várias fontes de EROs descritas até o momento, a NADPH oxidase destaca-se por gerar EROs como função primária deste complexo enzimático em neurônios, e não somente como produto secundário à sua ativação $(\mathrm{NOH}$ e $\mathrm{KOH}$, 2000; OHARA, 2006). Originalmente descrita em neutrófilos polimorfonucleares, esta proteína tem um papel importante na defesa contra infecções. Contudo, na última década, o conceito de que a ativação da NADPH oxidase teria apenas função microbicida foi reformulado para incluir uma visão muito mais atual de que esta 
enzima participa de um grande número de processos fisiológicos em virtualmente todas as células e tecidos. A produção de EROs pela NADPH oxidase regula inúmeros processos celulares tais como sobrevivência, proliferação, diferenciação, migração e apoptose (JONES, 2006; BEDARD e KRAUSE, 2007). Devido ao seu papel central na transdução de sinais, inúmeros estudos buscam compreender as vias responsáveis pela ativação e regulação da NADPH oxidase frente a diferentes estímulos.

Por serem ricos em ácidos graxos poliinsaturados e conseqüentemente susceptíveis ao dano oxidativo, a geração de EROs pela NADPH oxidase em neurônios foi desconsiderada por muito tempo. No entanto, atualmente sabe-se que no sistema nervoso esta enzima está envolvida em processos fisiológicos como sinalização, memória e no controle cardiovascular central (INFANGER et al., 2006).

Neste trabalho, observou-se com de ensaios de RT-PCR o aumento da expressão gênica de Nox 1, Nox 2 e Nox 4 no CS, em diferentes períodos após enucleação ocular. Já no GLD, não foram observadas alterações no padrão de expressão de Nox 1. Contudo, os ensaios revelaram aumento de expressão de Nox 2 e redução significativa na expressão de Nox 4. Em conjunto, estes dados fornecem evidências diretas da participação da NADPH oxidase como fonte geradora de EROs no CS e no GLD do tálamo após enucleação ocular. Neurônios expressam as isoformas da NADPH oxidase Nox 1 (IBI et al., 2006), Nox 2 (TAMMARIELLO et al., 2000) e Nox 4 (VALLET et al., 2005). Além disso, outros trabalhos também revelaram a presença destas isoformas em células da glia (PAWATE et al., 2004; ABRAMOV et al., 2005; SORCE e KRAUSE, 2009). Contudo, considerando a metodologia empregada no presente estudo, não foi possível evidenciar alguma expressão diferencial das isoformas da NADPH em neurônios e em células da glia.

Resultados obtidos por meio da técnica de imuno-histoquímica revelaram que a enucleação ocular é capaz de promover o aumento da imunorreatividade para as proteínas estruturais NFs e MAP-2 no CS e no GLD. Tais resultados foram também evidenciados no CS por ensaios de immunoblotting. O aumento da síntese protéica 
de NFs e de MAP-2 observados neste trabalho deve indicar o remodelamento de neurônios em estruturas retinorrecipientes após a lesão.

O termo plasticidade neuronal se refere às mudanças adaptativas na estrutura e função dos neurônios que podem contribuir para processos de aprendizagem, memória, além de estarem envolvidas com a adaptação de uma estrutura a lesões. O citoesqueleto neuronal é composto por 3 filamentos interconectados: microfilamentos de actina, microtúbulos e filamentos intermediários (SANCHEZ et al., 2000). Neurofilamentos, filamentos intermediários característicos de neurônios, são os mais abundantes polímeros estruturais de axônios mielinizados (SZARO e STRONG, 2009). Estes polipeptídeos são formados por proteínas de baixo (NF68), médio (NF160) e alto (NF200) peso molecular. Tais proteínas são abundantemente distribuídas em axônios, corpos celulares e dendritos (VAN DER ZEE et al., 1997). A má formação e acúmulo de proteínas mal formadas foram observadas em diversas neuropatologias como a esclerose lateral amniotrófica e a DP. Diversos fatores podem contribuir para o acúmulo de NFs mal formados, incluindo alterações na síntese proteica, no transporte axonal e nos níveis de fosforilação e proteólise (BARRY et al., 2007). Contudo, em animais knockouts para NF68 a regeneração de axônios mielinizados foi significativamente reduzida após axotomia, demonstrando que NFs contribuem para a regeneração das fibras nervosas após lesões. Além disso, o aumento da expressão de NF200 elevou em $65 \%$ a expectativa de vida de camundongos transgênicos para a SOD (COUILLARDDESPRES et al., 1998). Desta maneira, o aumento da expressão de NFs tem sido constantemente associado a efeitos neuroprotetores. Aparentemente, estas proteínas seriam capazes de agirem como quelantes de cálcio por possuírem múltiplos sítios de ligação para este íon (JULIEN, 1999).

No encéfalo adulto, MAP-2 são proteínas abundantes em dendritos e corpos celulares, responsáveis pelo crescimento e arborização dendrítica, remodelamento dendrítico após lesões e estabelecimento e manutenção da sinaptogênese (TUCKER, 1990; JOHNSON e JOPE, 1992). Especula-se que MAP-2 sejam capazes de regular o crescimento e a polaridade neuronal por modular a dinâmica dos 
microtúbulos no citoplasma, controlando assim o equilíbrio entre a rigidez e a plasticidade em processos neuronais (SANCHEZ et al., 2000). Portanto, existe um grande interesse no estudo dos eventos fisiopatológicos que possam controlar a expressão de MAPs, alterando a dinâmica e a organização do citoesqueleto neuronal. Foi observado, por exemplo, que áreas do encéfalo envolvidas na aquisição e consolidação de memória sofrem redução da integridade estutural e da plasticidade dependente de MAP-2 com o envelhecimento (DI STEFANO et al., 2006). Em consonância com nossos resultados, observou-se aumento da imunorreatividade para MAP-2 no giro denteado do hipocampo de ratos adultos até 6 meses após lesão unilateral do córtex entorrinal. De acordo com os autores, tais achados sugerem um fenômeno de plasticidade neuronal no cérebro adulto após a lesão (KWAK e MATUS, 1988).

Digno de nota é que ambos os tratamentos, crônico e agudo, com apocinina atenuaram a expressão proteica de NFs e MAP-2 no CS e no GLD, sugerindo que EROs geradas pela NADPH oxidase estão envolvidas em eventos de remodelamento neuronal pós-lesão, bem como na manutenção destes mecanismos de plasticidade.

\subsection{CONCLUSÕES}

Em conjunto, os resultados obtidos sugerem que a enucleação ocular é capaz de induzir aumento da geração de EROs dependentes da NADPH oxidase em estruturas retinorrecipientes. Os dados também sugerem que este fenômeno deve mediar mecanismos de plasticidade sináptica em áreas visuais após a lesão. 


\section{CAPÍTULO III: ATIVAÇÃO DE CÉLULAS DA GLIA E DO FATOR DE TRANSCRIÇÃO NF-KB INDUZIDOS POR ENUCLEAÇÃO OCULAR}

\subsection{INTRODUÇÃO}

\subsubsection{O fator de transcrição NF-кB e sua ativação}

O fator de transcrição NF-кB (nuclear factor кB) é um complexo multiproteico capaz de regular a atividade de uma grande variedade de genes envolvidos em diversos processos biológicos como inflamação, desenvolvimento, plasticidade e neurodegeneracão. Em células de mamíferos, о NF-кB pode ser formado por homo ou heterodímeros das subunidades c-Rel, Rel A (p65), Rel B, p50 e p62. Todas as proteínas constituintes da família do NF-кB possuem um domínio N-terminal conhecido como domínio homólogo-Rel, o qual regula a dimerização das subunidades, promove a ligação do NF-кB ao DNA, bem como sua interação com a proteína inibitória ІкB (BEINKE e LEY, 2004).

Em células não estimuladas, о NF-кB pode ser encontrado no citoplasma de forma latente, formando um complexo com o ІкB, que impede que o NF-кB entre no núcleo e se ligue ao DNA. O evento regulatório crítico para a ativação do NF-кB é a fosforilação da proteína ІкB pelo complexo ІкB quinase (IKK). Classicamente, ocorre a rápida fosforilação da proteína IKBa pela IKK $\beta$, que é subseqüentemente degradada pelo proteassoma 26S (OLIVEIRA-MARQUES et al., 2009). Desta maneira, o NF-кB livre migra para o núcleo e induz a expressão de genes alvo. Entre os principais genes alvos podemos destacar a ciclooxigenase-2 (COX-2), a NOS induzida, a SOD, o fator de necrose tumoral, entre outros (GLEZER et al., 2003). De acordo com Schreck e colaboradores (SCHRECK et al., 1992), por induzir a expressão de genes com funções antioxidantes como a SOD e também a tiorredoxina (uma enzima envolvida com a redução de cisteínas em proteínas comprometidas pelo dano 
oxidativo), a ativação do NF-кB faz parte de um importante sistema de resposta ao estresse oxidativo. Neste sentido, Schreck e colaboradores (SCHRECK et al., 1992) constituíram o primeiro grupo a relatar o fato de que EROs também atuariam como segundos mensageiros envolvidos com a ativação do NF-kB. Esta hipótese foi concebida diante de quatro principais evidências experimentais: (1) $\mathrm{H}_{2} \mathrm{O}_{2}$ pode diretamente ativar o NF-KB em diversos tipos celulares; (2) a ativação é suprimida por uma grande variedade de antioxidantes, a despeito da fonte estimuladora. (3) inibição ou aumento da expressão de enzimas que modulam as concentrações intracelulares de EROs também é capaz de modular a ativação do NF-KB por alguns agentes estimuladores; (4) grande parte dos agentes que induzem a ativação do NFKB estimulam a produção de EROs.

Vários são os estímulos capazes de desencadear a ativação do NF-KB , incluindo o glutamato, citocinas como interleucina 1 e fator de necrose tumoral, aumento da concentração intracelular de cálcio, neurotrofinas e proteínas neurotóxicas como a $\beta$-amilóide (BOWIE e O'NEILL, 2000). Além disso, aumento da demanda pelo processamento de proteínas recém-formadas, também é capaz de ativar o NF-KB, muito embora os mecanismos envolvidos sejam desconhecidos (PAHL e BAEUERLE, 1996; DENG et al., 2004).

Diversos estudos relataram o aumento da ativação do NF-KB no tecido cerebral em modelos animais de acidente vascular cerebral, isquemia transiente, choque traumático, privação de sono, entre outros (PRASAD et al., 1994; YANG et al., 1995; GRILLI et al., 1996; CARROLL et al., 1998; BRANDT et al., 2004). Contudo, não existem relatos da ativação deste fator de transcrição em estruturas do sistema visual em particular. 


\subsubsection{Células gliais: aspectos gerais}

No SNC, duas grandes classes de células gliais foram descritas, de acordo com a dimensão de seus corpos celulares: macroglia (astrócitos e oligodendrócitos) e microglia. Os astrócitos possuem morfologia bastante característica, com prolongamentos numerosos que emergem do corpo celular que se ramificam profusamente, formando uma densa arborização (LENT, 2001; BEAR et al., 2008). Ao longo de muitos anos de estudos, múltiplas funções foram atribuídas a astrócitos, como a regulação do conteúdo químico no espaço extracelular e o controle da movimentação de fluidos entre o espaço extracelular e intracelular. Além disso, astrócitos parecem ser determinantes na resposta tecidual à isquemia e lesões (ANDERSON et al., 2003). Processos responsáveis pela ativação de astrócitos, um fenômeno também conhecido como gliose reativa, são bastante complexos e incluem alterações morfológicas importantes e liberação de citocinas pró-inflamatórias como interleucinas e fator de necrose tumoral a (LYNCH, 2009). Este fenômeno foi descrito em diversos tipos de lesão do SNC, como em quadros de isquemia, hipóxia e acidente vascular cerebral (PEKNY e NILSSON, 2005).

Oligodendrócitos também possuem prolongamentos que emergem do corpo celular; contudo, tais prolongamentos não são tão numerosos e ramificados como os de astrócitos. Os prolongamentos de oligodendrócitos enrolam-se em torno de axônios do SNC, produzindo a bainha de mielina neuronal (LENT, 2001; BEAR, 2008). Anormalidades na mielinização de neurônios estão envolvidas em uma grande variedade de doenças neurológicas e podem também contribuir para 0 desenvolvimento de transtornos neuropsiquiátricos (NAVE, 2010).

As células da microglia possuem características fenotípicas de macrófagos e de monócitos e são consideradas como importantes coordenadores da resposta imunológica do SNC. Constituindo de 10 a 20\% das células do SNC, sabe-se que este tipo celular possui atividade fagocítica e prolifera consideravelmente em casos de lesão, em modelos experimentais de estresse e em quadros de doenças degenerativas. Nestes casos, células da microglia liberam EROs e ERN, proteínas 
envolvidas com processos inflamatórios como citocinas e quimiocinas, além de desempenharem importantes funções fagocíticas, auxiliando na remoção de debris celulares (WU et al., 2009; LYNCH, 2009). Assim como astrócitos, células da microglia expressam transportadores de glutamato, o que também sugere seu envolvimento no controle da citotoxicidade glutamatérgica (PERSSON et al., 2005). 


\subsection{OBJETIVOS}

\section{Objetivo geral}

Neste capítulo foi avaliada a hipótese de que a enucleação ocular pode desencadear uma resposta inflamatória no CS após a enucleação ocular.

Para tanto, objetivou-se especificamente:

- Avaliar o efeito da enucleação ocular sobre a expressão protéica de astrócitos, microglia e de ciclooxigenase-2 no colículo superior em diversos períodos após enucleação ocular.

- Investigar o efeito do tratamento com DEX sobre a imunorreatividade para GFAP (astrócitos) e OX42 (microglia) no colículo superior 7 dias após enucleação ocular.

- Analisar o efeito da enucleação ocular sobre a ativação do NF-KB no colículo superior, bem como sua resposta frente ao tratamento com DEX. 


\subsection{MATERIAL E MÉTODOS}

\subsubsection{Animais}

Foram utilizados ratos machos (Rattus novergicus) da linhagem Wistar, adultos, pesando entre 180 e $200 \mathrm{~g}$, provenientes do Biotério Central do Instituto de Ciências Biomédicas da Universidade de São Paulo. Os animais foram mantidos em temperatura controlada $\left(23^{\circ} \pm 2{ }^{\circ} \mathrm{C}\right)$, ciclo claro/escuro de 12 horas, $60 \%$ de umidade. Foram alimentados com ração padrão e água ad libitum. Todos os procedimentos realizados neste trabalho foram aprovados pela Comissão de Ética em Experimentação Animal (CEEA) do Instituto de Ciências Biomédicas da Universidade de São Paulo (protocolo nº17/2007).

\subsubsection{Procedimento cirúrgico}

Para a realização da enucleação ocular os animais foram anestesiados com quetamina (5 mg/100 g de peso) e xilazina (1 mg/100g de peso), ambos por via intramuscular. O globo ocular direito foi completamente removido e, em seguida, foi aplicado um anestésico local (lidocaína). O espaço antes ocupado pelo globo ocular foi preenchido com material sintético de fibrina (Gelfoam, Upjohn, Michigan, USA), para acelerar o processo de cicatrização. As pálpebras foram então suturadas com fio cirúrgico e, imediatamente após o término do procedimento, os animais retornaram as suas gaiolas. As sobrevidas escolhidas dos animais foram 1 hora, 1, 7, 15 e 30 dias. Os animais do grupo controle não sofreram nenhum tipo de lesão. 


\subsubsection{Immunoblotting}

Sete dias após a lesão os animais foram sacrificados por decapitação e o CS foi rapidamente coletado e homogeneizado com o auxílio de um sonicador em tampão de extração (100mM de Tris pH7,4, 100mM de pirofosfato de sódio, 100mM de fluoreto de sódio, $10 \mathrm{mM}$ de EDTA, $10 \mathrm{mM}$ de ortovanadato de sódio, $2 \mathrm{mM}$ de PMSF e $0,01 \mathrm{mg} / \mathrm{ml}$ de aprotinina). Posteriormente, as amostras foram incubadas com $1 \%$ de Triton-X 100 por 30 minutos a $4{ }^{\circ} \mathrm{C}$, e em seguida centrifugadas a 12.000 rpm a $4{ }^{\circ} \mathrm{C}$ por 20 minutos para a remoção do material insolúvel. Parte do sobrenadante foi utilizada para determinação do conteúdo protéico por espectrofotometria, utilizando-se o reagente para ensaio de proteína (BioRad Protein Assay-Dye Reagent Concentratei; Melville, NY), e foi utilizada curva padrão de albumina como referência. O restante do sobrenadante foi diluído em tampão Laemmli (azul de bromofenol 0.1\%, fosfato de sódio $1 \mathrm{M} \mathrm{pH} \mathrm{7,0,} \mathrm{glicerol} 50 \%$ e SDS $10 \%$ ) contendo $200 \mathrm{mM}$ de DTT (ditiotreitol), em proporção de 5:1 e fervidas por 5 minutos. As amostras assim obtidas foram congeladas e mantidas a $-70{ }^{\circ} \mathrm{C}$ até sua utilização. De 50 a 100mg de proteína total foram submetidos a eletroforese em gel bifásico (gel de empilhamento e gel de resolução 8\%) em aparelho para minigel de poliacrilamida (Mini-Protean, Bio-Rad; Melville, NY), juntamente com marcador de peso molecular pré-corado disponível comercialmente (Bio-Rad; Melville, NY). A transferência das proteínas foi feita eletricamente para uma membrana de nitrocelulose (Amersham Biosciences; Piscataway, NJ), utilizando aparato para transferência semi-seca (Bio-Rad; Melville, NY) e realizada durante 2 horas a 120V em gelo, banhada com tampão de transferência.

Após a transferência, as membranas foram incubadas com solução bloqueadora constituída de $5 \%$ de leite desnatado diluído em solução basal (10 mM de Tris, $150 \mathrm{mM}$ de $\mathrm{NaCl}$ e $0,02 \%$ de Tween 20 ) a $4{ }^{\circ} \mathrm{C}$ overnight ou à temperatura ambiente, durante 2 horas. Em seguida, as membranas foram lavadas 4 vezes durante 5 minutos com solução basal sob agitação. Posteriormente foram incubadas 
com o anticorpo específico contra OX42 (Biosciences, CA, EUA), GFAP (Immunon, Pittsburgh, PA, EUA), COX-2 (Abcam, Cambridge, Reino Unido) ou p50 (Santa Cruz, CA, EUA) na concentração final de 1:1000 overnight, a $4{ }^{\circ} \mathrm{C}$. Após incubação, as membranas foram lavadas 3 vezes durante 10 minutos com solução basal sob agitação e incubadas, à temperatura ambiente, com anticorpos secundários anti-lgG ligados à peroxidase (HRP), por 1 hora. A seguir, as membranas foram lavadas com solução basal sob agitação e reveladas. Para revelação utilizou-se o kit de quimioluminescência ECL (Amersham Biosciences; Piscataway, NJ). As soluções $1 \mathrm{e}$ 2 do kit foram adicionadas na proporção 1:1, recobrindo as membranas e após 1 minuto de reação as membranas foram secas em papel de filtro e expostas a filme de raio-X.

\subsubsection{Análise dos resultados}

A intensidade das bandas reativas formadas foi quantificada por densitometria óptica (Scion Image - Release Beta 3b, NIH, USA) e corrigida pela densidade observada para a $\beta$-actina, considerando-se as amostras dos animais controles como o padrão para a normalização dos resultados.

\subsubsection{Histoquímica}

Sete dias após a lesão os animais foram anestesiados e submetidos à perfusão transcardíaca, com solução salina tamponada seguida de solução fixadora constituída de $4 \%$ de paraformaldeído (PFA) dissolvido em tampão fosfato salina $0,1 \mathrm{M}(\mathrm{PB}$ pH 7,4). Após a perfusão, os encéfalos foram coletados e mantidos em $4 \%$ de PFA durante 4 horas. Após este período, o encéfalo foi transferido para uma solução de PB contendo $30 \%$ de sacarose, para crioproteção, por um período de 48 
horas. Em seguida, o encéfalo foi cortado em um micrótomo deslizante para congelamento. Os cortes histológicos, com $30 \mu \mathrm{m}$ de espessura, foram colocados em placa de cultivo de 6 compartimentos.

\subsubsection{Imunoperoxidase}

Os cortes foram submetidos a três lavagens de 10 minutos cada, em PB; b) em seguida incubados "overnight" à temperatura ambiente, em solução incubadora, que continha PB-T ( $0,3 \%$ de Triton X-100), $5 \%$ de soro normal de cabra e anticorpo monoclonal de camundongo dirigido contra a proteína GFAP (1:1000) (Sigma, MI, EUA) ou anticorpo monoclonal de camundongo dirigido contra a proteína OX42 (1:1000) (BD Biosciences, CA, EUA) c) após período de incubação, os cortes foram submetidos a três lavagens de 10 minutos cada com PB; d) os cortes foram incubados durante duas horas à temperatura ambiente, com anticorpo secundário biotinilado, diluído a 1:200 em PB contendo 0,3\% de Triton X-100; e) após este período, submetidos a três lavagens de 10 minutos em $P B$; f) incubados novamente com um complexo avidina-biotina-peroxidase (ABC-Elite, Vector, CA, USA) preparada com $10 \mu \mathrm{L}$ da solução $\mathrm{A}$ e $10 \mu \mathrm{L}$ da solução $B$ por $\mathrm{mL}$ de $\mathrm{PB}$ contendo $0,3 \%$ de Triton $\mathrm{X}-100$ e $\mathrm{NaCl}(0,3 \mathrm{M}-0,5 \mathrm{M})$ durante 1 hora e meia à temperatura ambiente; g) submetidos a três lavagens com PB durante 10 minutos cada.

A marcação com peroxidase foi realizada utilizando o cromógeno 3,3'diaminobenzidina (DAB) dissolvido em PB durante 3 minutos, e em seguida foi adicionada uma solução de $0,3 \%$ de peróxido de hidrogênio em água destilada. Após o desenvolvimento da cor, os cortes foram lavados três vezes com PB de 10 minutos cada. Os cortes foram então colocados sobre lâminas de vidro gelatinizadas e deixados por aproximadamente 24 horas em uma placa de aquecimento a $37^{\circ} \mathrm{C}$ para uma melhor adesão dos cortes nas lâminas. Em seguida, as lâminas foram deixadas por 5 minutos em água destilada e mergulhadas em uma solução de $0,05 \%$ de 
tetróxido de ósmio por aproximadamente 15 segundos para intensificação da marcação. Logo após, as lâminas foram submetidas a 3 lavagens de 10 minutos cada em PB e submetidas a uma bateria de desidratação, que consiste em uma série crescente de álcoois e por um solvente clareador (Hemo-De, Fisher, PA, USA) com duração de 5 minutos para cada estágio. As lâminas foram então cobertas com lamínulas usando Permount (Fisher, PA, USA) como meio de montagem e analisadas em microscópio óptico acoplado a um sistema de análise de imagens baseado no programa NIH (USA).

\subsubsection{Imunofluorescência}

Os cortes foram submetidos a três lavagens de 10 minutos cada, em PB; b) em seguida incubados por 48 horas à temperatura ambiente, em solução incubadora, que continha PB-T ( $0,3 \%$ de Triton X-100), $5 \%$ de soro normal de cabra e anticorpo monoclonal de coelho dirigido contra a proteína p65 diluído a 1:500; c) após período de incubação, os cortes foram submetidos a três lavagens de 10 minutos cada com PB; d) os cortes foram incubados durante duas horas à temperatura ambiente, com anticorpo secundário marcado com o fluoróforo isotiocianato de fluoresceína (FITC) diluído a 1:200 em PB contendo 0,3\% de Triton X-100; e) após este período, submetidos a três lavagens de 10 minutos em PB. A seguir, os cortes foram montados em lâminas gelatinizadas, cobertos com glicerol e tampão carbonato e lamínulas. As lâminas foram analisadas em microscópio óptico e a intensidade da imunorreatividade produzida pelos anticorpos foi avaliada. 


\subsubsection{Ensaio de gel de retardo (electrophoretic mobility gel shift assay EMSA) para NF-KB}

\subsubsection{Extração de proteínas nucleares}

O método utilizado foi descrito por Rong e Baudry em 1996 (RONG e BAUDRY, 1996). Após diversos tempos de sobrevida, os animais foram sacrificados por decapitação e o colículo superior foi rapidamente coletado e homogeneizado em tampão fosfato salina (PBS: $\mathrm{NaCl} 137 \mathrm{mM}, \mathrm{KCl} 2,68 \mathrm{mM}, \mathrm{KH}_{2} \mathrm{PO}_{4} 1,27 \mathrm{mM}, \mathrm{Na}_{2} \mathrm{HPO}_{4}$ $8,06 \mathrm{mM}$ ) gelado adicionado de inibidores de proteases (PMSF 0,5M, DTT 0,5M, leupeptina $2 \mu \mathrm{g} / \mathrm{mL}$ e antipaína $2 \mu \mathrm{g} / \mathrm{mL}$ ) e EDTA 0,1 mM. Em seguida, o homogenato foi centrifugado a $12.000 \times \mathrm{g}$ por 30 segundos a $4{ }^{\circ} \mathrm{C}$, descartando-se $\mathrm{O}$ sobrenadante. O pellet foi então ressuspendido em tampão de lise (HEPES $10 \mathrm{mM}$, $\mathrm{MgCl}_{2} 1,5 \mathrm{mM}, \mathrm{KCl} 10 \mathrm{mM}$, PMSF 0,5M, DTT 0,5M, leupeptina $2 \mu \mathrm{g} / \mathrm{mL}$ e antipaína 2 $\mu \mathrm{g} / \mathrm{mL}$ ) e incubado em gelo durante 10 minutos. Foi adicionado então NP40 10\%, as amostras foram novamente centrifugadas a $12.000 \times \mathrm{g}$ por 30 segundos a $4{ }^{\circ} \mathrm{C}$ e $\mathrm{O}$ sobrenadante descartado. $O$ pellet foi ressuspendido em tampão de extração (HEPES 20mM, glicerol 25\%, $\mathrm{MgCl}_{2} 1,5 \mathrm{mM}, \mathrm{NaCl} 300 \mathrm{mM}$, EDTA 0,25mM, PMSF 0,5M, DTT 0,5M, leupeptina $2 \mu \mathrm{g} / \mathrm{mL}$ e antipaína $2 \mu \mathrm{g} / \mathrm{mL}$ ) e incubado por 20 minutos em gelo. As amostras foram centrifugadas a $12.000 \times \mathrm{g}$ a $4{ }^{\circ} \mathrm{C}$, o sobrenadante recolhido e a concentração de proteínas determinada. As amostras foram estocadas a $-80^{\circ} \mathrm{C}$ até o momento de sua utilização.

\subsubsection{Marcação da Sonda}

O oligonucleotídeo de DNA contendo a sequência (5'AGT TGA GGG GAC TTT CCC AGG C- 3') foi marcado pela adição de $Y^{-32}$ P ATP em uma solução 
contendo tampão $T_{4}$ quinase e água, nas concentrações de: 3,5 pmol de oligonucleotídeo, $1 \mathrm{U} / \mu \mathrm{L}$ de $\mathrm{T}_{4}$ quinase, $1 \mu \mathrm{L}$ de $\mathrm{Y}^{-}{ }^{32} \mathrm{P}$ ATP (3Ci/mmol), $1 \mu \mathrm{L}$ de tampão quinase buffer (10x) em $10 \mu \mathrm{L}$ de volume de reação. Após incubação a $37^{\circ} \mathrm{C}$ por 10 minutos, o excesso de $\mathrm{Y}^{-}{ }^{32} \mathrm{P}$ ATP foi retirado com resina sephadex G-25. Foram colocadas colunas (Microspin G-25) em um tubo de microcentrífuga, centrifigando-se por 1 minuto a $3.000 \mathrm{rpm}$. A coluna foi transferida para um novo tubo aplicando-se a sonda marcada no centro da resina. Após centrifugação, o eluato é recolhido e no dia do ensaio a atividade da sonda foi determinada.

\subsubsection{Reação de ligação e corrida do gel}

Foram adicionados a um tubo de microcentrífuga: $4 \mu \mathrm{L}$ de tampão de ligação $5 \mathrm{X}\left(\mathrm{MgCl}_{2} 5 \mathrm{mM}\right.$, EDTA 2,5mM, DTT 2,5mM, NaCl $300 \mathrm{mM}$, Tris- $\mathrm{HCl} 50 \mathrm{mM}$, Poly dldc $0,25 \mu \mathrm{g} / \mu \mathrm{L}$ e glicerol $20 \%$ ), extrato nuclear na quantidade suficiente para $25 \mu \mathrm{g}$ de proteína, oligo frio em excesso e $\mathrm{H}_{2} \mathrm{O}$ q.s.p. para $20 \mu \mathrm{L}$ de volume final (contando com a adição da sonda marcada).

O material foi incubado por 20 minutos em temperatura ambiente, adicionando-se em seguida a sonda marcada $(1 \mu \mathrm{L})$, e novamente foi incubado por 30 minutos em temperatura ambiente. A corrida foi visualizada com a adição de $1 \mu \mathrm{L} \mathrm{de}$ bromofenol ao controle (-). O conteúdo total do meio de reação foi aplicado ao gel de poliacrilamida 5,5\% [acrilamida/bisacrilamida(37,5:1)]. Para a eletroforese foi utilizado um tampão de corrida constituído por 0,5 x TBE (TBE: Tris $90 \mathrm{mM}$, ácido bórico 90mM, EDTA 1mM). A corrida teve uma duração aproximada de 2 horas a 150-160 V. Ao final da corrida o gel foi secado procedendo-se em seguida a exposição do filme ao gel em cassete a $-20^{\circ} \mathrm{C}$. 


\subsubsection{Revelação}

Em sala escura, o filme foi mergulhado em solução reveladora diluída 5 vezes até as bandas aparecerem, lavando-se em água e depois mergulhando-se o filme em solução fixadora.

\subsubsection{Análise dos resultados}

A intensidade das bandas reativas formadas foi quantificada por densitometria óptica (Scion Image - Release Beta 3b, NIH, USA), considerando-se as amostras dos animais controles como o padrão para a normalização dos resultados.

\subsubsection{Tratamento com dexametasona}

Animais enucleados foram tratados com DEX (1mg/kg i.p., por 3 dias) de acordo com protocolo descrito por Barel e colaboradores (BAREL et al., 2010). Animais do grupo controle receberam injeções de salina, o veículo de diluição da droga. Os encéfalos coletados foram utilizados em experimentos de imunohistoquímica e em ensaios de gel de retardo para NF-KB .

\subsubsection{Medida de glicemia}

Os níveis de glicemia foram monitorados por leitura de glicofita, contendo sangue obtido por punção da parte distal da cauda do rato. A leitura foi realizada em 
glicosímetro específico (One-touch Ultra, Johnsons and Johnsons, Milpitas, CA, EUA), através do qual os valores da glicemia foram obtidos em miligramas por decilitro (mg.dL-1). Foram realizadas três medidas de glicemia, a primeira antes do início do tratamento ( $\left.1^{\circ} \mathrm{dia}\right)$, a segunda no final do tratamento $\left(3^{\circ} \mathrm{dia}\right)$ e a terceira no dia em que os animais foram sacrificados ( $7^{\circ} \mathrm{dia}$ ).

\subsubsection{Análise estatística}

Os dados estão representados como média \pm e.p.m. A análise estatística dos dados foi gerada utilizando o programa GraphPad Prism, versão 3.02 (GraphPad Software Inc., San Diego, CA, USA). A comparação estatística entre os grupos foi realizada usando a análise de variância (ANOVA) de duas vias. O índice de significância foi considerado de $p \leq 0,05$. 


\subsection{RESULTADOS}

\subsubsection{Immunoblotting}

Foi observado aumento na expressão proteica de GFAP, OX42 e COX-2 no CS diversos períodos após a enucleação ocular de acordo com o ilustrado na Figura 3.1. O aumento da expressão de GFAP foi evidenciado 7 (551\%) e 15 (240\%) dias pós-lesão. Considerando a expressão proteica de OX42, resultados semelhantes foram encontrados 7 (205\%) dias pós-lesão. O conteúdo protéico de COX-2 revelouse significativamente aumentado 1 hora (287\%), 1 dia (258\%) e 7 dias (218\%) após a lesão. A incubação das membranas com anticorpo anti p50 não revelou a presença desta subunidade nas amostras (dados não mostrados).

\subsubsection{Imuno-histoquímica}

Corroborando os resultados obtidos pela técnica de immunoblotting, foi observado aumento da imunorreatividade para GFAP e OX42 no CS e no GLD sete dias após enucleação ocular. A proliferação de astrócitos e de microglia, representadas pela imunorreatividade para GFAP e OX42, foi reduzida em $62 \%$ e $35 \%$, respectivamente, após o tratamento com DEX (Figuras 3.2 e 3.3). Observou-se também o aumento da imunorreatividade para a subunidade p65 do NF-KB sete dias após enucleação ocular (Figura 3.6). 


\subsubsection{Ensaio de gel de retardo para NF-KB}

Verificou-se, por ensaio de gel de retardo, a ativação do NF-KB no CS de

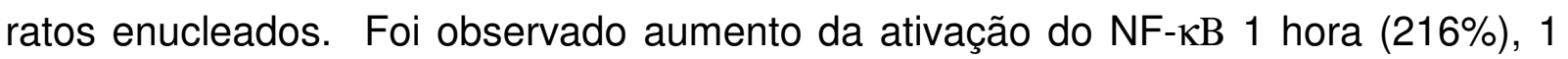
dia (223\%), 7 dias (292\%) e 15 dias (254\%) pós-lesão (Figura 3.4 A e B). De acordo com o que foi evidenciado em nossos ensaios de competição, a subunidade do NFKB ativada é a p65 (Figura 3.4 C).

O tratamento com DEX reduziu de maneira significativa (44\%) a ativação do NF-KB sete dias após a enucleação ocular (Figura 3.5).

\subsubsection{Medida de glicemia}

O tratamento com DEX por 3 dias não foi capaz de alterar os níveis de glicemia tanto de animais controles quanto de animais enucleados (dados não mostrados). 

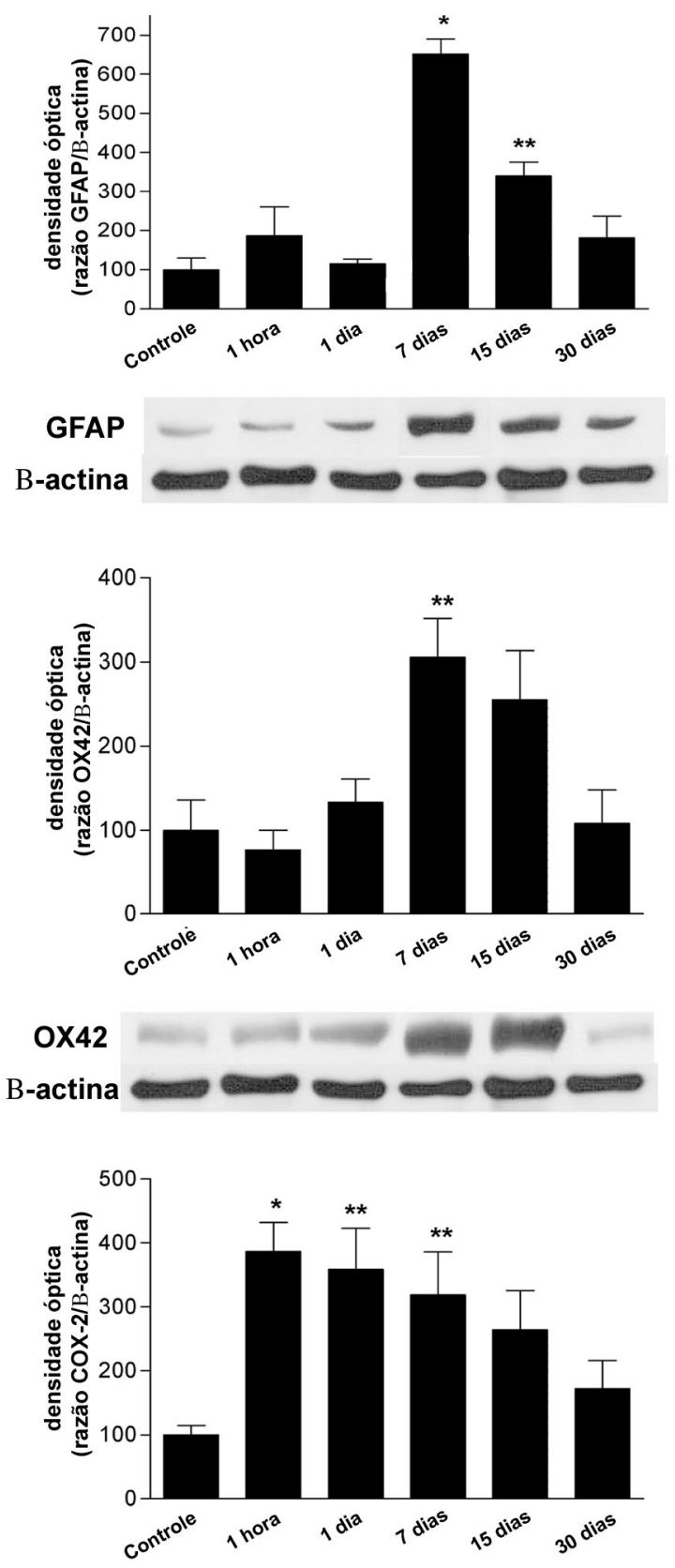

\section{cox-2}

B-actina

Figura 3.1 - Efeito da enucleação ocular sobre a expressão protéica de GFAP, OX42 e COX-2 no CS. Os gráficos representam a média da razão entre a densidade óptica das bandas das proteínas de interesse e da $\beta$-actina $(n=5)$. ${ }^{*} p<0,001$ e ${ }^{* *} p<0,05$ em comparação com 0 grupo controle. 


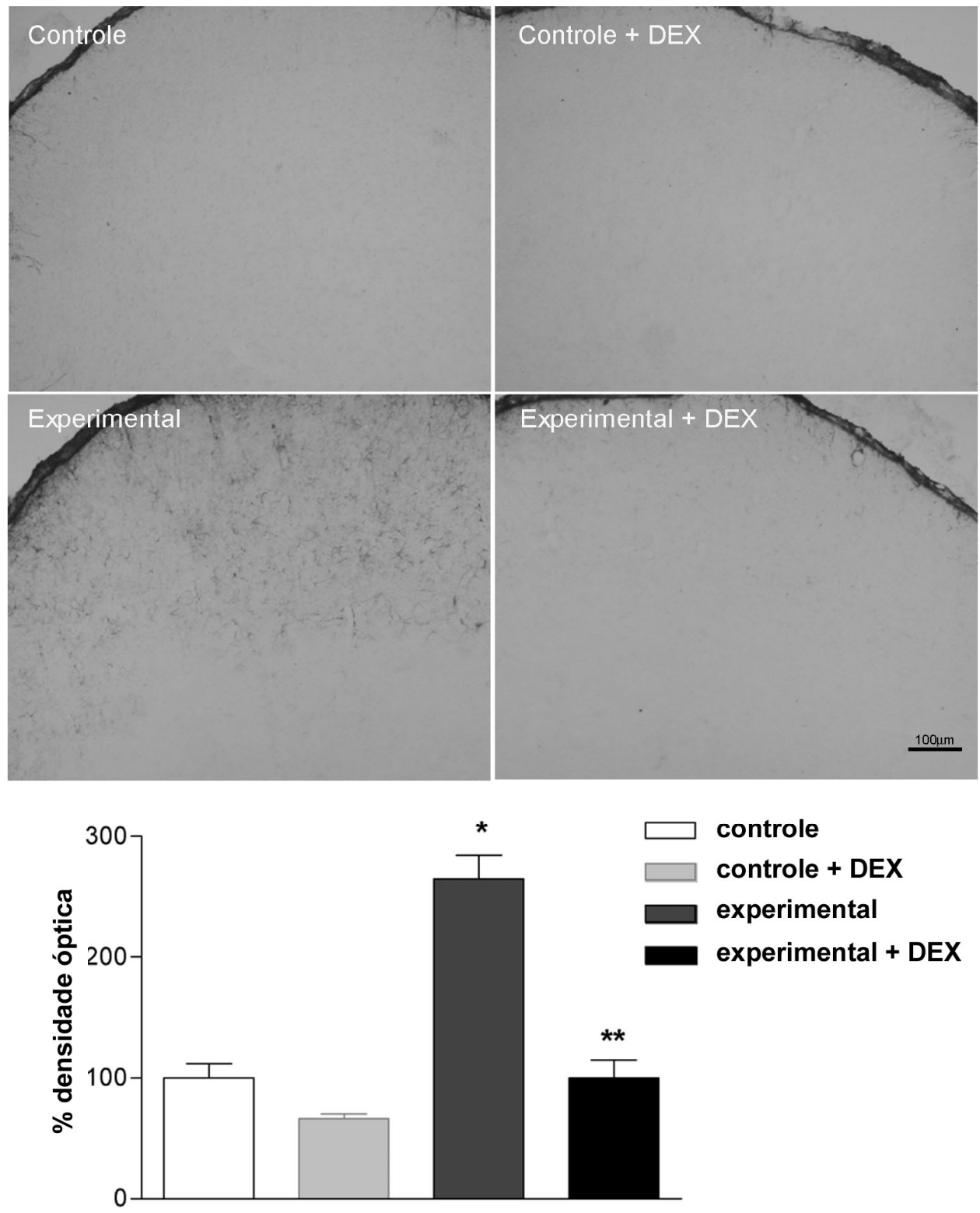

Figura 3.2 - Efeito do tratamento com dexametasona sobre a imunorreatividade para GFAP no CS 7 dias após enucleação ocular. Os valores do gráfico representam a análise da densidade óptica $(n=5)$ em animais do grupo controle, controles tratados com DEX, experimentais e experimentais tratados com DEX. ${ }^{*} p \quad<0,001$ (controle vs experimental $e^{* *} p<0,001$ (experimental vs experimental + DEX). DEX: dexametasona. 

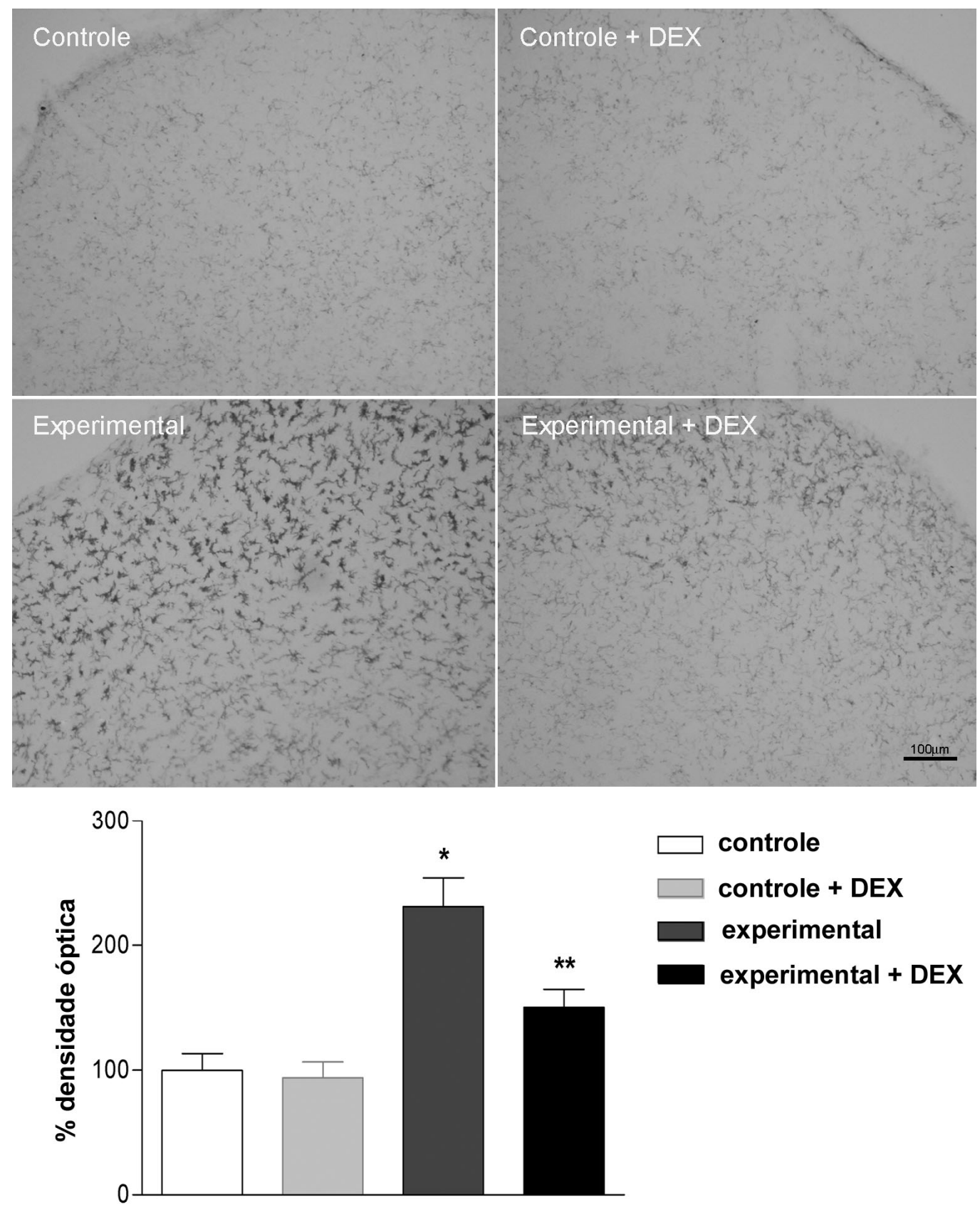

Figura 3.3 - Efeito do tratamento com dexametasona sobre a imunorreatividade para OX42 no CS sete dias após enucleação ocular. Os valores do gráfico representam a análise da densidade óptica $(n=5)$ em animais do grupo controle, controles tratados com DEX, experimentais e experimentais tratados com DEX. * $p \quad<0,001$ (controle vs experimental) and ${ }^{* *} p<0,05$ (experimental $v s$ experimental + DEX). DEX: dexametasona. 
A
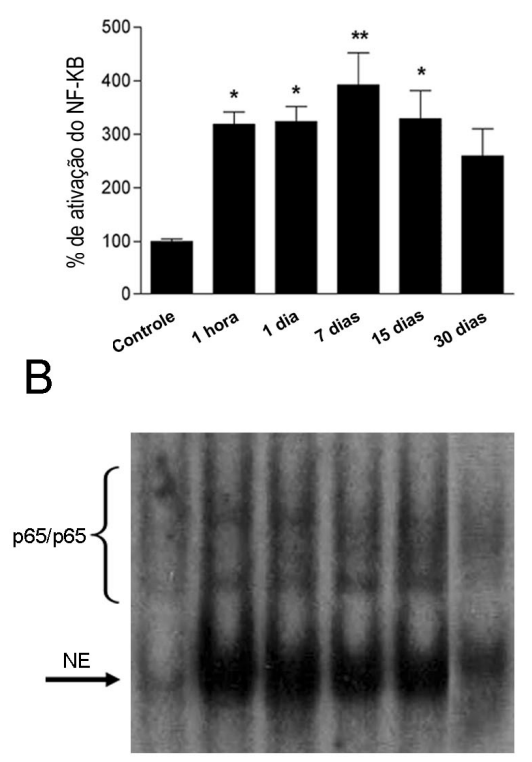

C

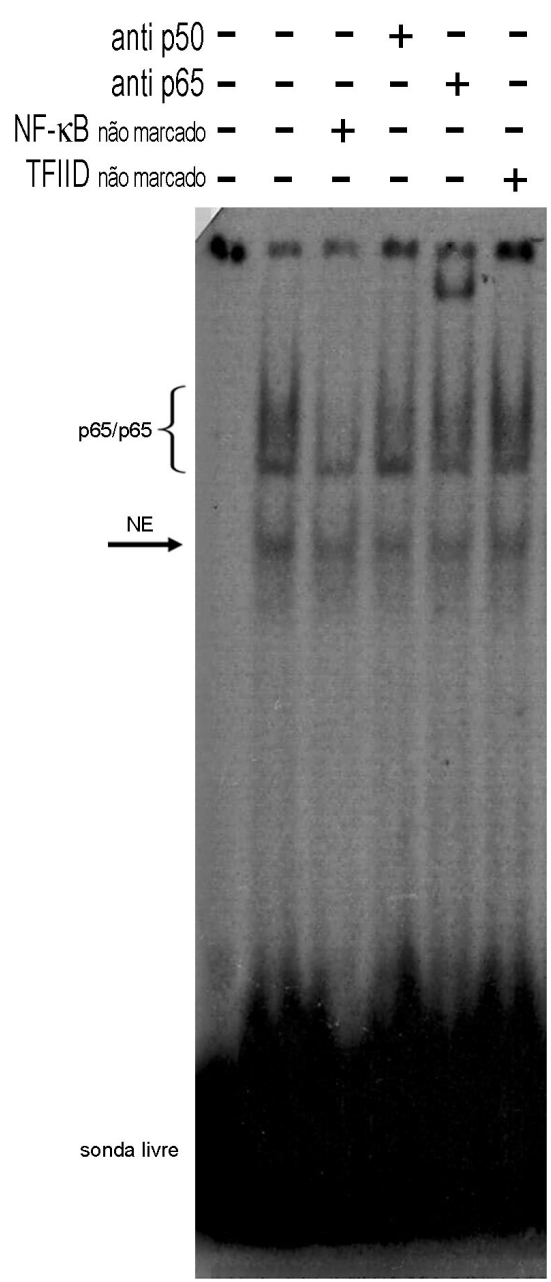

Figura 3.4 - Efeito da enucleação ocular sobre a ativação do NF-KB no CS. Os valores do gráfico representam a análise densitométrica das bandas p65/p65 obtidas de amostras do CS de ratos avaliados nos intervalos de 1 hora $1,7,15$ e 30 dias pós-lesão $(A) \cdot{ }^{*} p<0,01$ e ${ }^{* *} p<$ 0,001 vs controle. A posição da ligação do NF-KB ao DNA (subunidades p65/p65) foi indicada em B. Em C ensaio de competição realizado em amostras de CS obtidas 7 dias pós-lesão. As amostras foram incubadas com oligonucleotideo frio, com NF-KB não marcado, com anticorpo contra p50, anticorpo contra p65 e com oligonucleotideo inespecífico. O ensaio mostra o retardo da banda ainda maior na presença do anticorpo anti p65. NE representa uma banda não específica. A localização da sonda livre também foi indicada. 


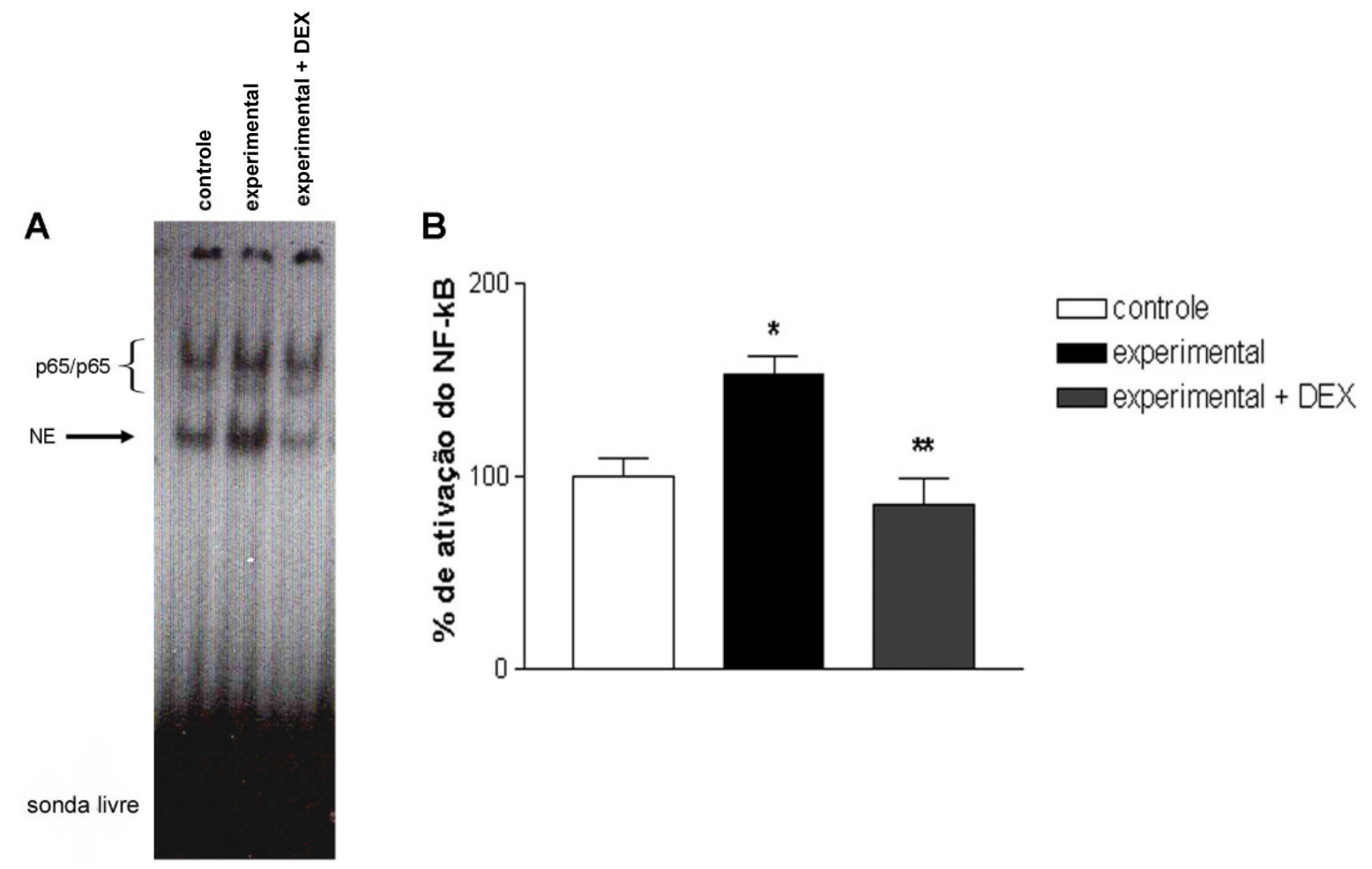

Figura 3.5 - Efeito do tratamento com dexametasona sobre a ativação do NF-KB no CS. Os valores do gráfico representam a análise densitométrica das bandas p65/p65 obtidas de amostras do CS de ratos avaliados 7 dias pós-lesão (A). * $p<0,05$ (controle vs experimental) $e^{* *} p<0,01$ (experimental $v s$ experimental + DEX). Em B imagens representativas obtidas de ensaio de gel de retardo para NF-KB . DEX: dexametasona. NE representa uma banda não específica. A localização da probe livre também foi indicada. 


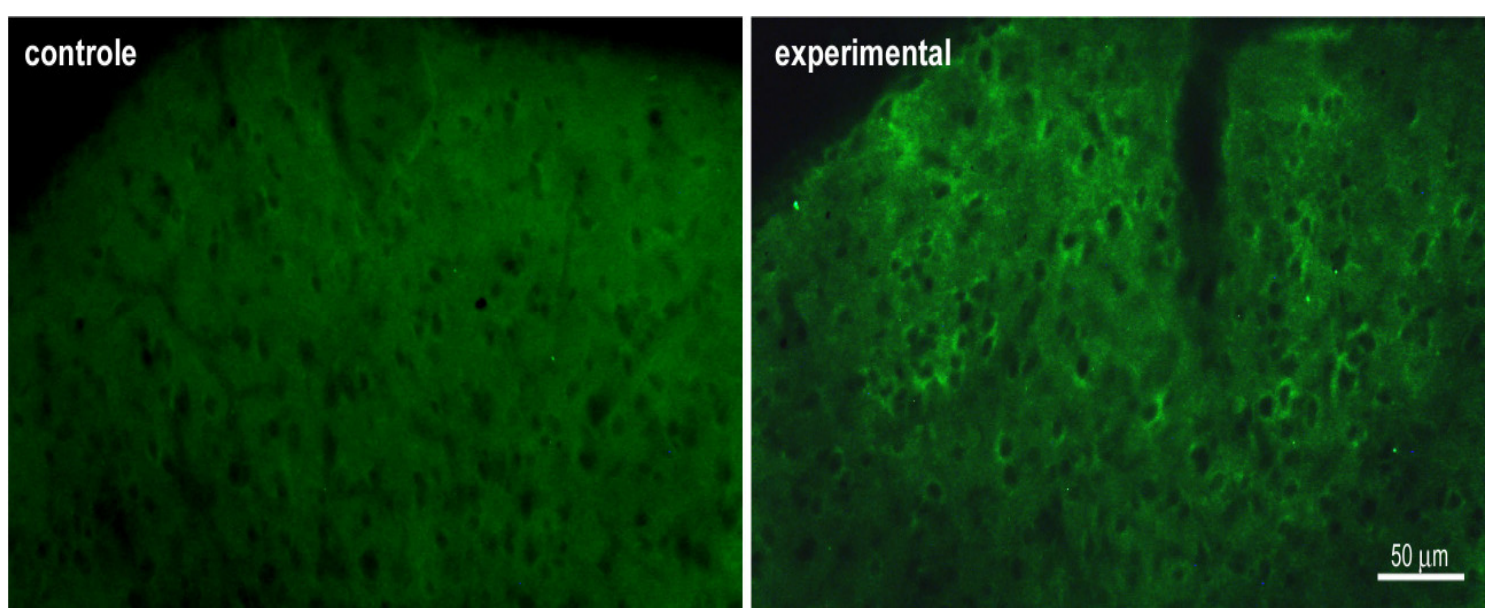

Figura 3.6 - Efeito da enucleação ocular sobre a imunorreatividade para p65 no CS sete dias após a lesão. 


\subsection{DISCUSSÃO}

Os resultados descritos neste capítulo ilustraram que a enucleação ocular promove a ativação transiente de astrócitos e de microglia no CS. A ativação do fator de transcrição NF-KB e da enzima ciclooxigenase também foi evidenciada. Estes resultados, aliados ao efeito da DEX sobre tais achados, estendem nossa compreensão acerca dos mecanismos desencadeados pela enucleação ocular em estruturas retinorrecipientes. Além disso, contribuem para a caracterização deste modelo de lesão do SNC.

Muito embora diversos trabalhos na literatura descrevam o envolvimento de células da microglia em processos que contribuem para a degeneração de neurônios, existem diversos relatos segundo os quais estas células também seriam capazes de promover neuroproteção (SIMARD et al., 2006; STREIT, 2006; EL KHOURY et al., 2007). A atividade fagocítica de células da microglia é determinante para a remoção de debris celulares provenientes de células apoptóticas, sendo que este mecanismo parece ser mediado por receptores de fosfatidilserina expressos na membrana destas células (DE SIMONE et al., 2003; MINGHETTI et al., 2005). Discute-se que durante curtos períodos após lesões do SNC a ativação de células da microglia esteja envolvida com a manutenção e reestabelecimento da homeostase, enquanto que a ativação sustentada destas células poderia ser extremamente prejudicial pela excessiva liberação de mediadores de inflamação (LYNCH, 2009). Neste sentido, a ativação transiente de células da microglia após enucleação ocular pode sugerir que tais células estejam envolvidas em processos de adaptação e reparo do CS, além da remoção de terminais axonais de células ganglionares da retina em degeneração.

De maneira bastante semelhante, em animais nocautes para GFAP, um marcador de filamentos intermediários produzido especificamente por astrócitos, observou-se a inibição de processos de recuperação frente a lesões (SMITH, 2003). Ainda, lesões realizadas por meio da utilização de agulhas no córtex cerebral de camundongos selvagens e camundongos nocautes para GFAP revelaram que a ativação de astrócitos participa de fenômenos de plasticidade pós-lesão (PEKNY et 
al., 1999). Tais evidências também poderiam sugerir o envolvimento de astrócitos na recuperação do CS após enucleação ocular.

O glicocorticóide DEX é comumente utilizado na recuperação pós-anestesia por possuir propriedades anti-eméticas, e, nos últimos anos, tem despertado o interesse por sua potente ação ant-iinflamatória e por seu importante potencial analgésico (ALLEN, 2007). A administração deste fármaco vem sendo utilizada em diversos modelos experimentais, e em geral seus efeitos incluem a redução de edema cerebral, diminuição da expressão de citocinas pró-inflamatórias, bem como diminuição da morte neuronal por apoptose (HOLMIN e MATHIESEN, 1996). Além disso, sabe-se que o tratamento com DEX inibe diretamente a ativação microglial (KIEFER e KREUTZBERG, 1991; GOTTSCHALI, 1996), além de atenuar a imunorreatividade para moléculas associadas com a ativação de microglia e macrófagos (ZHANG et al. 2007). No presente estudo, o tratamento com DEX foi utilizado com a finalidade de avaliarmos a hipótese da existência de uma resposta inflamatória no CS após a enucleação ocular.

De acordo com nossos resultados, a ativação de astrócitos e de microglia foi significativamente inibida pelo tratamento com o DEX. Resultados semelhantes foram descritos em outros modelos experimentais, como por exemplo em cultura de células da microglia (GANTER et al., 1992), após a inserção de próteses neurais no neocórtex de ratos (SPATARO et al., 2005) e após desaferentação hipocampal (WOODS et al., 1999). Contudo, diversos trabalhos descreveram os efeitos colaterais do tratamento com DEX. Uma única dose de DEX pode significativamente alterar o metabolismo de lipídeos e de carboidratos (QI et al., 2004) e induzir intolerância à glicose (SCHNEITER e TAPPY, 1998). As medidas de glicemia realizadas no presente estudo não revelaram alterações significativas nos níveis de glicemia de animais tratados por três dias com este glicocorticóide.

O ensaio de gel de retardo é considerado um dos métodos mais sensíveis de detecção de ligação de proteínas como o NF-KB ao DNA. Por meio da utilização deste ensaio, neste trabalho foi observada a ativação do NF-KB de uma hora até quinze dias após a enucleação ocular. Em consonância com nossos resultados, 
observou-se a ativação do NF-KB uma hora após a indução de choque endotóxico pela administração intravenosa de lipopolissacarídeos (LPS) (WANG e YANG, 2005). No hipocampo de ratos, o NF-KB foi ativado de quatro a dezesseis horas após a indução de epilepsia pela administração de kainato (RONG e BAUDRY,1996). Ainda, um dia após indução de lesão traumática, observou-se a ativação do NF-KB no córtex de ratos (YANG et al., 1995). O ensaio de competição realizado com as amostras de CS revelou um retardo da banda ainda maior na presença do anticorpo anti p65. Este resultado também foi evidenciado pelo aumento da imunorreatividade para p65 7 dias após enucleação ocular. Ainda, ensaios de immunoblotting realizados com a utilização de anticorpo contra p50 não revelaram a presença desta subunidade nas amostras de CS. Portanto, a partir dos dados apresentados, é possível supor a presença de homodímeros p65/p65 no CS.

Alguns trabalhos relativamente recentes demonstraram que a ativação do NF-KB é significativamente inibida pelo tratamento com DEX. Este tem sido considerado um mecanismo determinante na ação deste fármaco como antiinflamatório (NEWTON, 2000). Porém, estes trabalhos limitaram-se a avaliar o efeito da DEX in vitro em macrófagos e linfócitos. Contudo, corroborando os dados obtidos no presente estudo, a ativação do NF-KB induzida pela administração de LPS foi inibida pela injeção intraperitoneal de DEX (WANG e YANG, 2005). Discute-se que os mecanismos responsáveis pela inibição da ativação do NF-KB pela DEX involvam: (1) a ativação de receptores de glicocorticóides, os quais seriam capazes de inibir a translocação da subunidade p65 para o núcleo celular; e (2) o aumento da síntese da proteína inibitória IKB (SCHEINMAN et al., 1995; SCHEINMAN et al., 1995).

Em condições basais, a expressão da enzima COX-2 é praticamente indetectável na grande maioria dos tipos celulares de mamíferos. O aumento da expressão desta enzima pode ser induzido por uma série de estímulos próinflamatórios, além de estímulos que promovam o crescimento celular. A expressão do RNAm de COX-2 pode ser regulada por diversos fatores de transcrição, como a proteína de ligação ao elemento de resposta ao AMP cíclico (CREB) e o NF-KB (TSATSANIS et al., 2006). Desta maneira, por ser um dos genes responsivos à 
ativação do NF-KB, os resultados obtidos neste trabalho com a avaliação da expressão proteica de COX-2 em amostras de CS de animais enucleados sugerem indiretamente que a regulação da expressão gênica desta enzima possa ter sido induzida por este fator de transcrição. Especula-se que o aumento da ativação do NF-KB observado em amostras de neocórtex obtidas de pacientes com doença de Alzheimer também esteja relacionado com o aumento da transcrição genica de COX2 (LUKIW e BAZAN, 1998). Como ilustrado por nossos resultados, a ativação do NFKB ocorre concomitantemente ao aumento da transcrição genica de COX-2 em diversos tipos celulares tais como em células epiteliais e endoteliais humanas, em fibroblastos e linfoblastos humanos e em gliomas e fibroblastos de ratos (KOSAKA et al., 1994; NEWTON et al., 1997; LUKIW e BAZAN, 1998). Estes achados indicam que esta via de sinalização é comum a diversas espécies e tipos celulares. Contudo, sabe-se que o NO e EROs aumentam diretamente a atividade da COX-2 (SALVEMINI et al.. 1993; LANDINO et al., 1996). De acordo com o que foi evidenciado em experimentos realizados por nosso grupo de pesquisa, observou-se aumento na síntese de NO no CS após enucleação ocular (CHACUR et al., 2006). Além disso, no Capítulo II deste trabalho discutimos evidências de que a enucleação ocular promove o aumento da geração de EROs em estruturas retinorrecipientes. Tais resultados também poderiam sugerir o envolvimento de espécies reativas no aumento da expressão proteica de COX-2. 


\subsection{CONCLUSÕES}

Os resultados obtidos no Capítulo III sugerem que a enucleação ocular é capaz de induzir a ativação transiente de astrócitos e de microglia no CS. Observouse também a ativação concomitante do fator de transcrição NF-KB e da enzima COX2. A ativação de astrócitos e de microglia, bem como a ativação do NF-KB, foi reduzida pelo tratamento com DEX. Em conjunto, os resultados apresentados sugerem que a enucleação ocular pode desencadear uma resposta inflamatória no CS. 


\subsection{CONCLUSÕES GERAIS}

Com base nos resultados obtidos neste trabalho, pode-se concluir que a enucleação ocular é capaz de promover mudanças plásticas morfofuncionais no encéfalo de ratos adultos, como alterações de elementos estruturais de neurônios e de populações de células da glia. Demonstramos também que essas alterações podem ser influenciadas pelo tratamento com antioxidantes e com anti-inflamatórios. Estes resultados contribuem para a caracterização deste modelo de lesão do sistema visual e podem auxiliar na compreensão de mecanismos neurodegenerativos e de neuroplasticidade do sistema nervoso. 


\section{REFERÊNCIAS*}

ABRAHAMSON, E. E.; MOORE, R. Y. Suprachiasmatic nucleus in the mouse: retinal innervation, intrinsic organization and efferent projections. Brain Res., v. 916, n. 12, p. 172-191, 2001.

ABRAMOV, A. Y. et al. Expression and modulation of an NADPH oxidase in mammalian astrocytes. J. Neurosci., v. 25, p. 40, p. 9176-9184, 2005.

ALLEN, K. Dexamethasone: An All Purpose Agent? Australian Anaesthesia, v. 3, p. 65-70, 2007.

AMBASTA, R. K. et al. Direct interaction of the novel Nox proteins with p22phox is required for the formation of a functionally active NADPH oxidase. J. Biol. Chem., v. 279, n. 44, p. 45935-45941, 2004.

ANDERSEN, J. K. Oxidative stress in neurodegeneration: cause or consequence? Nat. Med., v. 10, p. S18-25, 2004.

ANDERSON, M. F. et al. Astrocytes and stroke: networking for survival? Neurochem. Res., v. 28, n. 2, p. 293-305, 2003.

ARRIGO, A. P. Gene expression and the thiol redox state. Free Radic. Biol. Med., v. 27, n. 9-10, p. 936-944, 1999.

BABIOR, B. M. NADPH oxidase: an update. Blood, v. 93, n. 5, p. 1464-1476, 1999.

BAREL, M. et al. Exercise training prevents hyperinsulinemia, muscular glycogen loss and muscle atrophy induced by dexamethasone treatment. Eur. J. Appl. Physiol., v. 108, n. 5, p. 999-1007, 2010.

* De acordo com: ASSOCIAÇÃO BRASILEIRA DE NORMAS TÉCNICAS. NBR 6023: Informação e documentação: referências: elaboração. Rio de Janeiro, 2002. 
BARRY, D. M. et al. New movements in neurofilament transport, turnover and disease. Exp. Cell Res., v. 313, n. 10, p. 2110-2120, 2007.

BATISTA, S. Moléculas relacionadas com neuroproteção e neurodegeneração no sistema visual: efeitos de lesões periféricas e centrais. 2006. 138 f. Dissertação (Doutorado em Fisiologia e Biofísica) - Instituto de Ciências Biomédicas, Universidade de São Paulo, São Paulo, 2006.

BE, S. Organization of the rodent superior colliculus: some comparisons with other mammals. Behav. Brain Res., v. 3, n. 2, p. 175-188, 1981.

BEAR M. F.; CONNORS, B.; PARADISO M. Neurociências. Porto Alegre: Artmed, 2008.

BEDARD, K.; KRAUSE, K. H. The NOX family of ROS-generating NADPH oxidases: physiology and pathophysiology. Physiol. Rev., v. 87, n. 1, p. 245-313, 2007.

BEHRENS, M. M. et al. Ketamine-induced loss of phenotype of fast-spiking interneurons is mediated by NADPH-oxidase. Science, v. 318, n. 5856, p. 1645-1647, 2007.

BEINKE, S.; LEY S. C. Functions of NF-kappaB1 and NF-kappaB2 in immune cell biology. Biochem. J., v. 382, n. 2, p. 393-409, 2004.

BODEUTSCH, N. et al. Unilateral injury to the adult rat optic nerve causes multiple cellular responses in the contralateral site. J. Neurobiol., v. 38, n. 1, p. 116-128, 1999.

BOWIE, A.; O'NEILL, L. A. Oxidative stress and nuclear factor-kappaB activation: a reassessment of the evidence in the light of recent discoveries. Biochem. Pharmacol., v. 59, n. 1, p. 13-23, 2000.

BRANDT, J. A. et al. Sleep deprivation increases the activation of nuclear factor kappa B in lateral hypothalamic cells. Brain Res., v. 1004, n. 1-2, p. 91-97, 2004.

CAJAL, S. Histologie du systéme nerveux. Paris: Maloine, 1911. 
CARROLL, J. E. et al. Nuclear factor-kappa B activation during cerebral reperfusion: effect of attenuation with N-acetylcysteine treatment. Mol. Brain Res., v. 56, n. 1-2, p. 186-191,1998.

CERAVOLO, G. S. et al. Angiotensin II chronic infusion induces B1 receptor expression in aorta of rats. Hypertension, v. 50, n. 4, p. 756-761, 2007.

CHACUR, M. et al. Differential regulation of the neuronal isoform of nitric oxide synthase in the superior colliculus and dorsal lateral geniculate nucleus of the adult rat brain following eye enucleation. Int. J. Dev. Neurosci., v. 24, n. 7, p. 461-468, 2006.

CHALMERS, D. T.; MCCULLOCH, J. Alterations in neurotransmitter receptors and glucose use after unilateral orbital enucleation. Brain Res., v. 540, n. 1-2, p. 243-254, 1991.

CHALUPA, L. M.; LIA, B. The nasotemporal division of retinal ganglion cells with crossed and uncrossed projections in the fetal rhesus monkey. J. Neurosci., v. 11, n. 1, p. 191-202, 1991.

CHALUPA L. M.; WILLIAMS R. W. Eye, retina, and visual system of the mouse. London: Mit Press, 2008.

CHANNON, K. M.; GUZIK T. J. Mechanisms of superoxide production in human blood vessels: relationship to endothelial dysfunction, clinical and genetic risk factors. $\mathbf{J}$. Physiol. Pharmacol., v. 53, n. 4, p. 515-524, 2002.

CLEMPUS, R. E.; GRIENDLING, K. K. Reactive oxygen species signaling in vascular smooth muscle cells. Cardiovasc. Res., v. 71, n. 2, p. 216-225, 2006.

COLEMAN, J.; CLERICI, W. J. Extrastriate projections from thalamus to posterior occipital-temporal cortex in rat. Brain Res., v. 194, n. 1, p. 205-209, 1980.

COUILLARD-DESPRES, $S$. et al. Protective effect of neurofilament heavy gene overexpression in motor neuron disease induced by mutant superoxide dismutase.

Proc. Natl. Acad. Sci. U. S. A., v. 95, n. 16, p. 9626-9630, 1998. 
DARLEY-USMAR, V. et al. Nitric oxide and oxygen radicals: a question of balance. FEBS Lett., v. 369, n. 2-3, p. 131-135, 1995.

DE SIMONE, R. et al. Apoptotic PC12 cells exposing phosphatidylserine promote the production of anti-inflammatory and neuroprotective molecules by microglial cells. $\mathbf{J}$. Neuropathol. Exp. Neurol., v. 62, n. 2, p. 208-216, 2003.

DENG, J. et al. Translational repression mediates activation of nuclear factor kappa B by phosphorylated translation initiation factor 2. Mol. Cell Biol., v. 24, n. 23, p. 1016110168, 2004.

DEXTER, D. T. et al. Basal lipid peroxidation in substantia nigra is increased in Parkinson's disease. J. Neurochem., v. 52, n. 2, p. 381-389, 1989.

DI STEFANO, G. et al. Level and distribution of microtubule-associated protein-2 (MAP2) as an index of dendritic structural dynamics. Rejuvenation Res., v. 9, n. 1, p. 94-98, 2006.

DIKALOV, S. I. et al. Distinct roles of Nox1 and Nox4 in basal and angiotensin IIstimulated superoxide and hydrogen peroxide production. Free Radic. Biol. Med., v. 45 , n. 9, p. 1340-1351, 2008.

DREHER, B. et al. The morphology, number, distribution and central projections of Class I retinal ganglion cells in albino and hooded rats. Brain Behav. Evol., v. 26, n. 1, p. 10-48, 1985.

DROGE, W. Free radicals in the physiological control of cell function. Physiol. Rev., v. 82 , n. 1, p. 47-95, 2002.

EL KHOURY, J. et al. Ccr2 deficiency impairs microglial accumulation and accelerates progression of Alzheimer-like disease. Nat. Med., v. 13, n. 4, p. 432-438, 2007.

ESPLUGUES, J. V. NO as a signalling molecule in the nervous system. Br. J. Pharmacol., v. 135, n. 5, p. 1079-1095, 2002. 
FATOKUN, A. A. et al. Oxidative stress in neurodegeneration and available means of protection. Front. Biosci., v. 13, p. 3288-3311, 2008.

FERRETTI, G. et al. Increased levels of lipid hydroperoxides in plasma of patients with multiple sclerosis: a relationship with paraoxonase activity. Mult. Scler., v. 11, n. 6, p. 677-682, 2005.

FINK, B. et al. Detection of intracellular superoxide formation in endothelial cells and intact tissues using dihydroethidium and an HPLC-based assay. Am. J. Physiol. Cell Physiol., v. 287, n. 4, p. C895-902, 2004.

FLOYD, R. A. Antioxidants, oxidative stress, and degenerative neurological disorders. Proc. Soc. Exp. Biol. Med., v. 222, n. 3, p. 236-245, 1999.

FRIDOVICH, I. Superoxide anion radical (O2-.), superoxide dismutases, and related matters. J. Biol. Chem., v. 272, n. 30, p. 18515-18517, 1997.

GANTER, S. et al. Growth control of cultured microglia. J. Neurosci. Res., v. 33, n. 2, p. 218-230, 1992.

GARBETT, N. C. et al. Influence of the amino substituents in the interaction of ethidium bromide with DNA. Biophys. J., v. 87, n. 6, p. 3974-3981, 2004.

GERICH, F. J. et al. Mitochondrial inhibition prior to oxygen-withdrawal facilitates the occurrence of hypoxia-induced spreading depression in rat hippocampal slices. J. Neurophysiol., v. 96, n. 1, p. 492-504, 2006.

GILMAN, S. C. et al. Peroxide effects on [3H]L-glutamate release by synaptosomes isolated from the cerebral cortex. Neurosci. Lett., v. 140, n. 2, p. 157-160, 1992.

GLEZER, I. et al. MK-801 and 7-Ni attenuate the activation of brain NF-kappa B induced by LPS. Neuropharmacology, v. 45, n. 8, p. 1120-1129, 2003.

GO, Y. M. et al. H2O2-dependent activation of GCLC-ARE4 reporter occurs by mitogen-activated protein kinase pathways without oxidation of cellular glutathione or thioredoxin-1. J. Biol. Chem., v. 279, n. 7, p. 5837-5845, 2004. 
GODEMENT, P. et al. Prenatal and postnatal development of retinogeniculate and retinocollicular projections in the mouse. J. Comp. Neurol., v. 230, n. 4, p. 552-575, 1984.

GOODALE, M. A. et al. Visual orientation in the rat: a dissociation of deficits following cortical and collicular lesions. Exp. Brain Res., v. 31, n. 3, p. 445-457, 1978.

GOTTSCHALL, P. E. beta-Amyloid induction of gelatinase B secretion in cultured microglia: inhibition by dexamethasone and indomethacin. Neuroreport, v. 7, n. 18, p. 3077-3080, 1996.

GRECO, A. et al. Cerebrospinal fluid isoprostane shows oxidative stress in patients with multiple sclerosis. Neurology, v. 53, n. 8, p. 1876-1879, 1999.

GRILLI, M. et al. Neuroprotection by aspirin and sodium salicylate through blockade of NF-kappaB activation. Science, v. 274, n. 5291, p. 1383-1385, 1996.

GUZIK, T. J.; HARRISON, D. G. Vascular NADPH oxidases as drug targets for novel antioxidant strategies. Drug Discov. Today, v. 11, n. 11-12, p. 524-533, 2006.

HALLIWELL, B. Role of free radicals in the neurodegenerative diseases: therapeutic implications for antioxidant treatment. Drugs Aging, v. 18, n. 9, p. 685-716, 2001.

HALLIWELL, B.; WHITEMAN, M. Measuring reactive species and oxidative damage in vivo and in cell culture: how should you do it and what do the results mean? Br. J. Pharmacol., v. 142, n. 2, p. 231-255, 2004.

HANKINS, M. W. et al. Melanopsin: an exciting photopigment. Trends Neurosci., v. 31, n. 1, p. 27-36, 2008.

HARTING, J. K. et al. Anterograde degeneration study of the superior colliculus in Tupaia glis: evidence for a subdivision between superficial and deep layers. J._Comp. Neurol., v. 148, n. 3, p. 361-386, 1973.

HATTAR, S. et al. Central projections of melanopsin-expressing retinal ganglion cells in the mouse. J. Comp. Neurol., v. 497, n. 3, p. 326-349, 2006. 
HAYHOW W. R.; WEBB, C. Primary optic centers of the rat in relation to the terminal distribution of the crossed and uncrossed optic nerve fibers. J. Comp. Neurol., v. 118, p. 295-321, 1962.

HE, L. et al. Effect of p47phox gene deletion on ROS production and oxygen sensing in mouse carotid body chemoreceptor cells. Am. J. Physiol. Lung Cell Mol. Physiol., v. 289, n. 6, p. L916-924, 2005.

HENSLEY, K. et al. Electrochemical analysis of protein nitrotyrosine and dityrosine in the Alzheimer brain indicates region-specific accumulation. J. Neurosci., v. 18, n. 20, p. 8126-8132, 1998.

HICKEY, T. L.; SPEAR, P. D. Retinogeniculate projections in hooded and albino rats: an autoradiographic study. Exp. Brain Res., v. 24, n. 5, p. 523-529, 1976.

HIDALGO, C. et al. A role for reactive oxygen/nitrogen species and iron on neuronal synaptic plasticity. Antioxid. Redox Signal., v. 9, n. 2, p. 245-255, 2007.

HILENSKI, L. L. et al. Distinct subcellular localizations of Nox1 and Nox4 in vascular smooth muscle cells. Arterioscler. Thromb. Vasc. Biol., v. 24, n. 4, p. 677-683, 2004.

HOLMIN, S.; MATHIESEN, T. Dexamethasone and colchicine reduce inflammation and delayed oedema following experimental brain contusion. Acta Neurochir. (Wien), v. 138, n. 4, p. 418-424, 1996.

HORDIJK, P. L. Regulation of NADPH oxidases: the role of Rac proteins. Circ. Res., v. 98, n. 4, p. 453-462, 2006.

HWANH, C. et al. Oxidized redox state of glutathione in the endoplasmic reticulum. Science, v. 257, n. 5076, p. 1496-1502, 1992.

IBI, M. et al. NOX1/NADPH oxidase negatively regulates nerve growth factor-induced neurite outgrowth. Free Radic. Biol. Med., v. 40, n. 10, p. 1785-1795, 2006. 
INFANGER, D. W. et al. NADPH oxidases of the brain: distribution, regulation, and function. Antioxid. Redox Signal., v. 8, n. 9-10, p. 1583-1596, 2006.

JEFFERY, G. Retinal ganglion cell death and terminal field retraction in the developing rodent visual system. Brain Res., v. 315, n. 1, p. 81-96, 1984.

JEON, C. J. et al. The major cell populations of the mouse retina. J. Neurosci., v. 18, n. 21, p. 8936-8946, 1998.

JOHNSON, G. V.; JOPE R. S. The role of microtubule-associated protein 2 (MAP-2) in neuronal growth, plasticity, and degeneration. J. Neurosci. Res., v. 33, n. 4, p. 505-512, 1992.

JONES, B. E.; YANG T. Z. The efferent projections from the reticular formation and the locus coeruleus studied by anterograde and retrograde axonal transport in the rat. J. Comp. Neurol., v. 242, n. 1, p. 56-92, 1985.

JONES, D. P. Redefining oxidative stress. Antioxid. Redox Signal., v. 8, n. 9-10, p. 1865-1879, 2006.

JOSEPH, J. A. et al. Age differences in sensitivity to H2O2- or NO-induced reductions in $\mathrm{K}(+)$-evoked dopamine release from superfused striatal slices: reversals by PBN or Trolox. Free Radic. Biol. Med., v. 20, n. 6, p. 821-830, 1996.

JULIEN, J. P. Neurofilament functions in health and disease. Curr. Opin. Neurobiol., v. 9, n. 5, p. 554-560, 1999.

KAMSLER, A; SEGAL, M. Control of neuronal plasticity by reactive oxygen species. Antioxid. Redox Signal., v. 9, n. 2, p. 165-167, 2007.

KIEFER, R.; KREUTZBERG, G. W. Effects of dexamethasone on microglial activation in vivo: selective downregulation of major histocompatibility complex class II expression in regenerating facial nucleus. J. Neuroimmunol., v. 34, n. 2-3, p. 99-108, 1991. 
KIM, M. A.; JEON, C. J. Metabotropic glutamate receptor mGluR2/3 immunoreactivity in the mouse superior colliculus: co-localization with calbindin D28K. Neuroreport, v. 10, n. 6, p. 1341-1346, 1999.

KING, S. M. Escape-related behaviours in an unstable, elevated and exposed environment. II. Long-term sensitization after repetitive electrical stimulation of the rodent midbrain defence system. Behav. Brain Res., v. 98, n. 1, p 127-142, 1999.

KISHIDA, K. T.; KLANN, E. Sources and targets of reactive oxygen species in synaptic plasticity and memory. Antioxid. Redox Signal., v. 9, n. 2, p. 233-244, 2007.

KOSAKA, T. et al. Characterization of the human gene (PTGS2) encoding prostaglandin-endoperoxide synthase 2. Eur. J. Biochem., v. 221, n. 3, p. 889-897, 1994.

KUME, T. et al. Endogenous factors regulating neuronal death induced by radical stress. Biol. Pharm. Bull., v. 27, n. 7, p. 964-967, 2004.

KWAK, S.; MATUS, A. Denervation induces long-lasting changes in the distribution of microtubule proteins in hippocampal neurons. J. Neurocytol., v. 17, n. 2, p. 189-195, 1988.

LANDINO, L. M. et al. Peroxynitrite, the coupling product of nitric oxide and superoxide, activates prostaglandin biosynthesis. Proc. Natl. Acad. Sci. U. S. A., v. 93, n. 26, p. 15069-15074, 1996.

LANE, R. D. et al. Differential age-dependent effects of retinal deafferentation upon calbindin- and parvalbumin-immunoreactive neurons in the superficial layers of the rat's superior colliculus. Brain Res., v. 740, n. 1-2, p. 208-214, 1996.

LASHLEY, K. The mecanism of vision. The projection of the retina upon the primary optic centers in the rat. J. Comp. Neurol., v. 59, p. 341-373, 1934.

LENT, R. Cem bilhões de neurônios. São Paulo: Atheneu, 2001. 
LINDEN, R.; PERRY, V. H. Massive retinotectal projection in rats. Brain Res., v. 272, n. 1, p. 145-149, 1983.

LIPTON, S. A. Neuronal protection and destruction by NO. Cell Death Differ., v. 6, n. 10, p. 943-951, 1999.

LOPES, L. R. et al. Activation of the leukocyte NADPH oxidase by protein kinase $\mathrm{C}$ in a partially recombinant cell-free system. J. Biol. Chem., v. 274, n. 22, p. 1553315537, 1999.

LOPES, L. R. et al. NADPH-oxidase activity and lipid peroxidation in neutrophils from rats fed fat-rich diets. Cell Biochem. Funct., v. 17, n. 1, p. 57-64, 1999.

LU, F. et al. Oxidative damage to mitochondrial DNA and activity of mitochondrial enzymes in chronic active lesions of multiple sclerosis. J. Neurol. Sci., v. 177, n. 2, p. 95-103, 2000.

LUKIW, W. J.; BAZAN, N. G.Strong nuclear factor-kappaB-DNA binding parallels cyclooxygenase-2 gene transcription in aging and in sporadic Alzheimer's disease superior temporal lobe neocortex. J. Neurosci. Res., v. 53, n. 5, p. 583-592, 1998.

LUND, J. S. et al. Differential central distribution of optic nerve components in the rat. Brain Res., v. 116, n. 1, p. 83-100, 1976.

LYNCH, M. A. The multifaceted profile of activated microglia. Mol. Neurobiol., v. 40, n. 2, p. 139-156, 2009.

MAHADEV, K. et al. The NAD $(\mathrm{P}) \mathrm{H}$ oxidase homolog Nox4 modulates insulinstimulated generation of $\mathrm{H} 2 \mathrm{O} 2$ and plays an integral role in insulin signal transduction. Mol. Cell Biol., v. 24, n. 5, p. 1844-1854, 2004.

MASON, R.; GROOS, G. A. Cortico-recipient and tecto-recipient visual zones in the rat's lateral posterior (pulvinar) nucleus: an anatomical study. Neurosci. Lett., v. 25, n. 2, p. 107-112, 1981. 
MASOOD, A. et al. Reversal of oxidative stress-induced anxiety by inhibition of phosphodiesterase-2 in mice. J. Pharmacol. Exp. Ther., v. 326, n. 2, p. 369-379, 2008.

MATOS, R. Expressão dos receptores metabotrópicos de glutamato no sistema visual de ratos e pintos após enucleação ocular. 2007. 149 f. Dissertação (Doutorado em Fisiologia e Biofísica) - Instituto de Ciências Biomédicas, Universidade de São Paulo, São Paulo, 2007.

MCCORD, J. M.; FRIDOVICH, I. Superoxide dismutase. An enzymic function for erythrocuprein (hemocuprein). J. Biol. Chem., v. 244, n. 22, p. 6049-6055, 1969.

MCHAFFIE, J. G.; STEIN B. E. Eye movements evoked by electrical stimulation in the superior colliculus of rats and hamsters. Brain Res., v. 247, n. 2, p. 243-253, 1982.

MEISTER, A. On the antioxidant effects of ascorbic acid and glutathione. Biochem. Pharmacol., v. 44, n. 10, p. 1905-1915, 1992.

MILLER, R. F. D-Serine as a glial modulator of nerve cells. Glia, v. 47, n. 3, p. 275283, 2004.

MINGHETTI, L. et al. Microglial activation in chronic neurodegenerative diseases: roles of apoptotic neurons and chronic stimulation. Brain Res. Rev., v. 48, n. 2, p. 251-256, 2005.

MOORE, R. Y. Efferent projections of the intergeniculate leaflet and the ventral lateral geniculate nucleus in the rat. J. Comp. Neurol., v. 420, n. 3, p. 398-418, 2000.

MULLER, M.; HOLLANDER $\mathrm{H}$. A small population of retinal ganglion cells projecting to the retina of the other eye. An experimental study in the rat and the rabbit. Exp. Brain Res., v. 71, n. 3, p. 611-617, 1988.

NAUTA, W. J.; VAN STRAATEN, J. J. The primary optic centres of the rat. An experimental study by the Bouton' method. J. Anat., v. 81, n. 2, p. 127-134, 1947. 
NAVE, K. A. Myelination and support of axonal integrity by glia. Nature, v. 468, n. 7321, p. 244-252, 2010.

NEWTON, R. Molecular mechanisms of glucocorticoid action: what is important? Thorax, v. 55, n. 7, p. 603-613, 2000.

NEWTON, R. et al. Evidence for involvement of NF-kappaB in the transcriptional control of COX-2 gene expression by IL-1beta. Biochem. Biophys. Res. Commun., v. 237, n. 1, p. 28-32, 1997.

NEWTON, R. et al. Cytokine induction of cytosolic phospholipase A2 and cyclooxygenase-2 mRNA is suppressed by glucocorticoids in human epithelial cells. Life Sci., v. 60, n. 1, p. 67-78, 1997.

$\mathrm{NOH}, \mathrm{K} . \mathrm{M}$; $\mathrm{KOH}$, J. Y. Induction and activation by zinc of NADPH oxidase in cultured cortical neurons and astrocytes. J. Neurosci., v. 20, n. 23, p. RC111, 2000.

$\mathrm{NUCCl}, \mathrm{C}$. et al. Excitotoxic mechanisms of apoptosis in the mammalian visual system following monocular visual deprivation. Pharmacol. Toxicol., v. 91, n. 4, p. 153-157, 2002.

OHARA, A. Radicais livres bons, maus e naturais. São Paulo: Oficina de textos, 2006.

OKADA, Y. The distribution and function of gamma-aminobutyric acid (GABA) in the superior colliculus. Prog. Brain Res., v. 90, p. 249-262, 1992.

OLDS, M. E.; OLDS, J. Approach-escape interactions in rat brain. Am. J. Physiol., v. 203, p. 803-810, 1962

OLIVEIRA-MARQUES, V. et al. Role of hydrogen peroxide in NF-kappaB activation: from inducer to modulator. Antioxid. Redox Signal,. v. 11, p. 2223-2243, 2009.

PAHL, H. L.; BAEUERLE, P. A. Activation of NF-kappa B by ER stress requires both $\mathrm{Ca} 2+$ and reactive oxygen intermediates as messengers. FEBS Lett., v. 392, n. 2, p. 129-136, 1996. 
PANAGIS, L. et al. Unilateral optic nerve crush induces bilateral retinal glial cell proliferation. Eur. J. Neurosci., v. 21, n. 8, p. 2305-2309, 2005.

PAPPOLLA, M. A. et al. Immunohistochemical evidence of oxidative [corrected] stress in Alzheimer's disease. Am. J. Pathol., v. 140, n. 3, p. 621-628, 1992.

PAWATE, S. et al. Redox regulation of glial inflammatory response to lipopolysaccharide and interferongamma. J. Neurosci. Res., v. 77, n. 4, p 540-551, 2004.

PAXINOS, G.; WATSON, C. The rat brain in stereotaxic coordinates. San Diego: Elsevier Academic Press, 2005.

PEDERSEN, W. A. et al. Protein modification by the lipid peroxidation product 4hydroxynonenal in the spinal cords of amyotrophic lateral sclerosis patients. Ann. Neurol., v. 44, n. 5, p. 819-824, 1998.

PEKNY, M. et al. Abnormal reaction to central nervous system injury in mice lacking glial fibrillary acidic protein and vimentin. J. Cell Biol., v. 145, n. 3, 503-514, 1999.

PELLMAR, T. Electrophysiological correlates of peroxide damage in guinea pig hippocampus in vitro. Brain Res., v. 364, n. 2, p. 377-381, 1986.

PELLMAR, T. C. Peroxide alters neuronal excitability in the CA1 region of guinea-pig hippocampus in vitro. Neuroscience, v. 23, n. 2, p. 447-456, 1987.

PERRY, V. H. A tectocortical visual pathway in the rat. Neuroscience, v. 5, n. 5, 915-927, 1980.

PERSSON, M. et al. Lipopolysaccharide increases microglial GLT-1 expression and glutamate uptake capacity in vitro by a mechanism dependent on TNF-alpha. Glia, v. 51, n. 2, p. 111-120, 2005.

PETERSON, J. R. et al. Reactive oxygen species in the neuropathogenesis of hypertension. Curr. Hypertens. Rep., v. 8, n. 3, p. 232-241, 2006. 
POON, H. F. et al. Free radicals: key to brain aging and heme oxygenase as a cellular response to oxidative stress. J. Gerontol. A. Biol. Sci. Med. Sci., v. 59, n. 5, p. 478493, 2004.

PRASAD, A. V. et al. Nuclear factor-kappa B in rat brain: enhanced DNA-binding activity following convulsant-induced seizures. Neurosci. Lett., v. 170, n. 1, p. 145148, 1994.

QI, D. et al. Single-dose dexamethasone induces whole-body insulin resistance and alters both cardiac fatty acid and carbohydrate metabolism. Diabetes, v. 53, n. 7, p. 1790-1797, 2004.

RAMON Y CAJAL, S. The structure of the retina. Springfield: Thomas, 1972.

REDGRAVE, P. et al. Gnawing and changes in reactivity produced by microinjections of picrotoxin into the superior colliculus of rats. Psychopharmacology (Berl.), v. 75, n. 2, p. 198-203, 1981.

RIBAK, C. E.; PETERS, A. An autoradiographic study of the projections from the lateral geniculate body of the rat. Brain Res., v. 92, n. 3, p. 341-368, 1975.

RINALDI, M. et al. Evaluation of assays for the measurement of bovine neutrophil reactive oxygen species. Vet. Immunol. Immunopathol., v. 115, n. 1-2, p. 107-125, 2007.

RONG, Y.; BAUDRY, M. Seizure activity results in a rapid induction of nuclear factorkappa B in adult but not juvenile rat limbic structures. J. Neurochem., v. 67, n. 2, p. 662-668, 1996.

SAKURAI, T.; OKADA, Y. Selective reduction of glutamate in the rat superior colliculus and dorsal lateral geniculate nucleus after contralateral enucleation. Brain Res., v. 573, n. 2, p. 197-203, 1992.

SALVEMINI, D. et al. Nitric oxide activates cyclooxygenase enzymes. Proc. Natl. Acad. Sci. U. S. A., v. 90, n. 15, p. 7240-7244, 1993. 
SANCHEZ, C. et al. Phosphorylation of microtubule-associated protein 2 (MAP2) and its relevance for the regulation of the neuronal cytoskeleton function. Prog. Neurobiol., v. 61, n. 2, p. 133-168, 2000.

SAZONTOVA, T. G. et al. Dynamic changes in transcription factor HIF-1alpha, rapid response protein, and membrane structure resistance following acute hypoxia. Vestn. Ross. Akad. Med. Nauk., v. 2, p. 17-25, 2007.

SCHAFER, F. Q.; BUETTNER G. R. Redox environment of the cell as viewed through the redox state of the glutathione disulfide/glutathione couple. Free Radic. Biol. Med., v. 30, n. 11, p. 1191-1212, 2001.

SCHEINMAN, R. I. et al. Role of transcriptional activation of I kappa B alpha in mediation of immunosuppression by glucocorticoids. Science, v. 270, n. 5234, p. 283286, 1995.

SCHEINMAN, R. I. et al. Characterization of mechanisms involved in transrepression of NF-kappa B by activated glucocorticoid receptors. Mol. Cell Biol., v. 15, n. 2, p. 943-953, 1995.

SCHNEITER, P.; TAPPY L. Kinetics of dexamethasone-induced alterations of glucose metabolism in healthy humans. Am. J. Physiol., v. 275, n. 5, p. E806-813, 1998.

SCHRECK, R. et al. Nuclear factor kappa B: an oxidative stress-responsive transcription factor of eukaryotic cells (a review). Free Radic. Res. Commun., v. 17, n. 4, p. 221-237, 1992.

SEFTON, A. J.; HARVEY, A. Visual system. The rat nervous system. London: Elsevier, 2004.

SEFTON, A. J. et al. Cortical projections to visual centres in the rat: an HRP study. Brain Res., v. 215, n. 1-2, p. 1-13, 1981.

SETKOWICZ, Z. et al. Contralateral response of macrophages and astrocytes to injury in the cerebral hemisphere of 6-day-old rat following prenatal gamma irradiation. Int. J. Dev. Neurosci., v. 22, n. 1, p. 1-9, 2004. 
SHIMOHAMA, S. et al. Activation of NADPH oxidase in Alzheimer's disease brains. Biochem. Biophys. Res. Commun., v. 273, n. 1, p. 5-9, 2000.

SIMARD, A. R. et al. Bone marrow-derived microglia play a critical role in restricting senile plaque formation in Alzheimer's disease. Neuron, v. 49, n. 4, p. 489-502, 2006.

SMITH, C. V. et al. Compartmentation of glutathione: implications for the study of toxicity and disease. Toxicol. Appl. Pharmacol., v. 140, n. 1, p. 1-12, 1996.

SMITH, Q. R. A review of blood-brain barrier transport techniques. Methods Mol. Med., v. 89, p. 193-208, 2005.

SPATARO, L. et al. Dexamethasone treatment reduces astroglia responses to inserted neuroprosthetic devices in rat neocortex. Exp. Neurol., v. 194, n. 2, p. 289300, 2005.

SPENCER, J. P. et al. Conjugates of catecholamines with cysteine and GSH in Parkinson's disease: possible mechanisms of formation involving reactive oxygen species. J. Neurochem., v. 71, n. 5, p. 2112-2122, 1998.

STREIT, W. J. Microglial senescence: does the brain's immune system have an expiration date? Trends Neurosci., v. 29, n. 9, p. 506-510, 2006.

SUH, Y. A. et al. Cell transformation by the superoxide-generating oxidase Mox1. Nature, v. 401, n. 6748, p. 79-82, 1999.

SUZUKAWA, K. et al. Nerve growth factor-induced neuronal differentiation requires generation of Rac1-regulated reactive oxygen species. J. Biol. Chem., v. 275, n. 18, p. 13175-13178, 2000.

SZARO, B. G.; STRONG, M.J. Post-transcriptional control of neurofilaments: New roles in development, regeneration and neurodegenerative disease. Trends Neurosci., v. 33, n. 1, p. 27-37, 2009. 
TAKAHASHI, T. The organization of the lateral thalamus of the hooded rat. J. Comp. Neurol., v. 231, n. 3, p. 281-309, 1985.

TAMMARIELLO, S. P. et al. NADPH oxidase contributes directly to oxidative stress and apoptosis in nerve growth factor-deprived sympathetic neurons. J. Neurosci., v. 20, n. 1, p. RC53, 2000.

TASSINARI, G. et al. Overlapping ipsilateral and contralateral retinal projections to the lateral geniculate nucleus and superior colliculus in the cat: a retrograde triple labelling study. Brain Res. Bull., v. 43, n. 2, p. 127-139, 1997.

TORRES, M. Mitogen-activated protein kinase pathways in redox signaling. Front. Biosci., v. 8, p. 369-391, 2003.

TSATSANIS, C. et al., Signalling networks regulating ciclooxygenase-2. Int. J. Biochem. Cell Biol., v. 38, p. 1654-1661, 2006.

TSUKAMOTO, Y. et al. Microcircuits for night vision in mouse retina. J. Neurosci., v. 21, n. 21, p. 8616-8623, 2001.

TUCKER, R. P. The roles of microtubule-associated proteins in brain morphogenesis: a review. Brain Res. Rev., v. 15, n. 2, p. 101-120, 1990.

VALLET, P. et al. Neuronal expression of the NADPH oxidase NOX4, and its regulation in mouse experimental brain ischemia. Neuroscience, v. 132, n. 2: p. 233238, 2005.

VAN DER ZEE, E. A. et al. Age-dependent changes in the immunoreactivity for neurofilaments in rabbit hippocampus. Neuroscience, v. 79, n. 1, p. 103-116, 1997.

VIGNAIS, P. V. The superoxide-generating NADPH oxidase: structural aspects and activation mechanism. Cell Mol. Life Sci., v. 59, n. 9, p. 1428-1459, 2002.

VLADIMIROVA, O. et al. The activation of protein kinase $\mathrm{C}$ induces higher production of reactive oxygen species by mononuclear cells in patients with multiple sclerosis than in controls. Inflamm. Res., v. 48, n. 7, p. 412-416, 1999. 
WANG, J., YANG, G. Role of nuclear transcription factor-kappaB in endotoxininduced shock in rats. J. Huazhong Univ. Sci. Technolog. Med. Sci., v. 25, n. 2, p. 174-177, 2005.

WEILER, R., et al. Modulation of coupling between retinal horizontal cells by retinoic acid and endogenous dopamine. Brain Res Rev., v. 32, n. 1, p. 121-129, 2000.

WIESEL, T. N.; HUBEL, D. H. Effects of Visual Deprivation on Morphology and Physiology of Cells in the Cats Lateral Geniculate Body. J. Neurophysiol., v. 26, p. 978-993, 1963.

WINTERBOURN, C. C.; HAMPTON, M. B. Thiol chemistry and specificity in redox signaling. Free Radic. Biol. Med., v. 45, n. 5, p. 549-561, 2008.

WOODS, A. G. et al. Dexamethasone selectively suppresses microglial trophic responses to hippocampal deafferentation. Neuroscience, v. 91, n. 4, p. 1277-1289, 1999.

WU, C. Y. et al. Kv1.1 expression in microglia regulates production and release of proinflammatory cytokines, endothelins and nitric oxide. Neuroscience, v. 158, n. 4, p. $1500-1508,2009$.

WU, D. C. et al. The inflammatory NADPH oxidase enzyme modulates motor neuron degeneration in amyotrophic lateral sclerosis mice. Proc. Natl. Acad. Sci. U. S. A., v. 103, n. 32, p. 12132-12137, 2006.

YANG, K. et al. Increased cortical nuclear factor-kappa B (NF-kappa B) DNA binding activity after traumatic brain injury in rats. Neurosci. Lett., v. 197, n. 2, p. 101-104, 1995.

ZEMLAN, F. P. et al. Superoxide dismutase activity in Alzheimer's disease: possible mechanism for paired helical filament formation. Brain Res., v. 476, n. 1, p. 160-162, 1989. 
ZHANG, Z. et al. Dexamethasone attenuates early expression of three molecules associated with microglia/macrophages activation following rat traumatic brain injury. Acta Neuropathol., v. 113, n. 6, p. 675-682, 2007.

ZHAO, $\mathrm{H}$. et al. Superoxide reacts with hydroethidine but forms a fluorescent product that is distinctly different from ethidium: potential implications in intracellular fluorescence detection of superoxide. Free Radic. Biol. Med., v. 34, n. 11, p. 13591368, 2003.

ZIRPEL, L. et al. Deafferentation increases the intracellular calcium of cochlear nucleus neurons in the embryonic chick. J. Neurophysiol., v. 74, n. 3, p. 1355-1357, 1995. 


\begin{abstract}
ANEXOS
ANEXO A - Trabalho publicado no periódico Neuroscience
\end{abstract}


ANEXO B - Trabalho submetido para publicação no periódico Journal of Neuroscience Research 